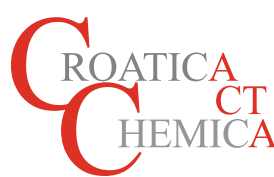

\title{
Ferrocene Bioconjugates
}

\author{
Mojca Čakić Semenčić, Lidija Barišić*
}

\begin{abstract}
Department of Chemistry and Biochemistry, Faculty of Food Technology and Biotechnology, University of Zagreb, Pierottijeva 6, HR-10000, Zagreb, Croatia
* Corresponding author's e-mail address: lidija.barisic@pbf.hr
\end{abstract}

RECEIVED: October 19, 2017 * REVISED: March 12, 2018 * ACCEPTED: March 26, 2018

THIS PAPER IS DEDICATED TO PROF. MLADEN ŽINIĆ ON THE OCCASION OF HIS 70 Th BIRTHDAY

\begin{abstract}
In this review we present our recent contribution to the field of bioorganometallic chemistry of ferrocene. Ferrocene conjugates with biomolecules have been synthesized and characterized using IR and NMR $\left({ }^{1} \mathrm{H},{ }^{13} \mathrm{C}, \mathrm{COSY}, \mathrm{NOESY}, \mathrm{HMBC}\right)$ spectroscopy, ESI-MS and HRMS. The bioconjugates of ferrocene with resveratrol (2) and mannose (10,11, 14 and 15) were biologically evaluated for their potential inhibitory effect on HepG2 cancer cells (2) and E. coli adherence to the bladder epithelium (10,11, 14 and 15). The oxalamide-bridged ferrocene 17 was subjected to conformational analysis in solution and in the solid state, and tested for its gelation and cytotoxic activity. The mono- (30-32, 36-38, 42-45) and disubstituted ferrocene conjugates with natural amino acids $(21-28,33-35,39-41,48,49,62-65,69-72)$ were subjected to the detailed conformational and DFT analyses in order to determine the turn-inducing potential of ferrocene scaffolds in the corresponding peptidomimetics.
\end{abstract}

Keywords: ferrocene, resveratrol, mannose, oxalamide, peptide, cytoxic activity, hemagglutination, gelation, conformational analysis, peptidomimetics.

\section{INTRODUCTION}

$\mathbf{F}$ ERROCENE was serendipitously discovered 66 years ago when Pauson and Kealy tried unsuccessfully to prepare fulvalene $\left(\mathrm{C}_{10} \mathrm{H}_{8}\right)$ by reaction of cyclopentadiene bromide with iron (II) chloride. Instead of fulvalene, they obtained the orange solid that was consistent with molecular formula $\mathrm{FeC}_{10} \mathrm{H}_{10} .^{[1]}$ A year later, Wilkinson and Woodward[2] deduced the real structure of the novel compound - $\left[\mathrm{Fe}\left(\mathrm{C}_{5} \mathrm{H}_{5}\right)_{2}\right]$ - where two anionic cyclopentadienyl $(C p)$ rings donate $6 \pi$ electrons to the $\mathrm{Fe}^{2+}$ cation sandwiched between them. Since its reactivity resembles that of benzene, the name ferrocene for the novel sandwich complex was coined. ${ }^{[3,4]}$ It soon became apparent that ferrocene features several types of remarkable properties: solubility in common organic solvents, stability up to $400{ }^{\circ} \mathrm{C}$, reactivity as a superaromatic electrophile and mild and reversible oxidation around $+0.4 \mathrm{~V}$ vs. saturated calomel electrode (SCE) (Figure 1).

So far, ferrocenes have been reported in more than 18000 papers (Web of Science) ) $^{[5]}$ and as such are recognized as an icon of organometallic chemistry. The recently published microreview on ferrocenes ${ }^{[5]}$ gives an overview of ferrocene applications in fields such as nanomedicine, biological sensing (the detection of glucose in blood, ${ }^{6]}$ protein and DNA binding, immunoassay tracers, ${ }^{, 7]}$ etc.), catalysis, battery and other materials, and other areas involving supramolecular, macromolecular, and optoelectronic property aspects.

Owing to their exceptional characteristics (stability in biological media, redox activity, easy penetration through cell membrane owing to the lipophilicity, low toxicity, feasibility to chemical modification, commercial

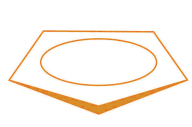

$-0.4 \vee$ vs. SCE
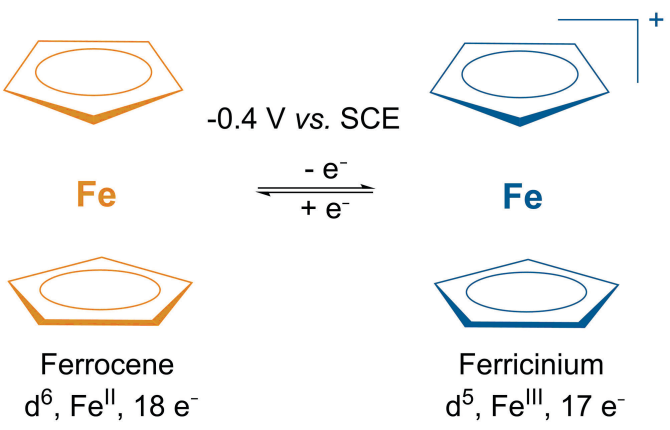

Figure 1. Reversible oxidation of ferrocene to the ferricinium ion.

(cc) BY This work is licensed under a Creative Commons Attribution 4.0 International License. 


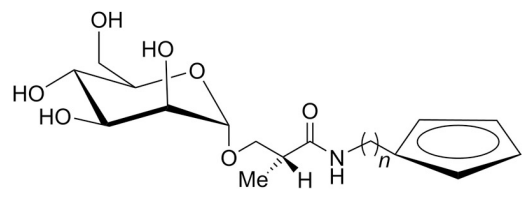

$\mathrm{Fe}$

$$
\text { a, } n=0, \mathrm{R}=\mathrm{H}
$$

I $\quad$ b, $n=0, R=$ COOMe c, $n=1, \mathrm{R}=\mathrm{H}$

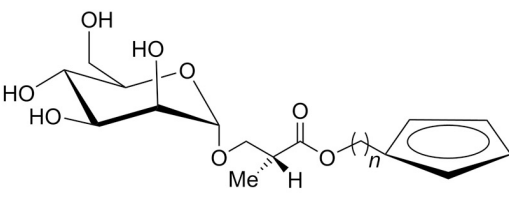

$\mathrm{Fe}$

a, $n=1, \mathrm{R}=\mathrm{COOMe}$

II $\quad \mathbf{b}, n=1, \mathrm{R}=\mathrm{NHBoc}$ c, $n=2, \mathrm{R}=\mathrm{H}$

Figure 2. The mannose-containing ferrocenes I and II.

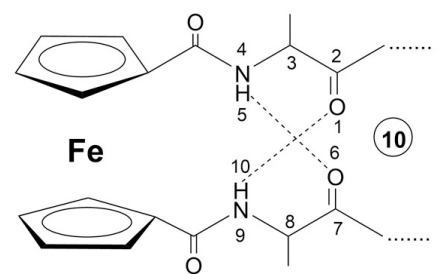

III

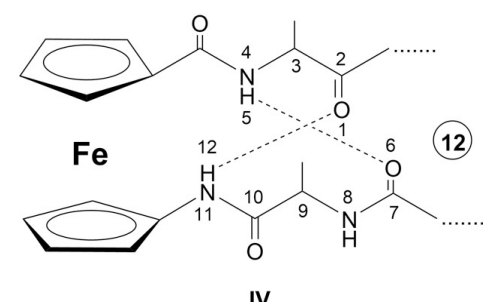

IV

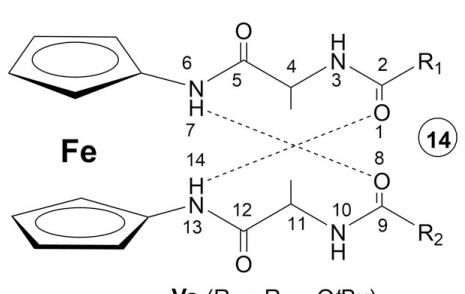

$\mathrm{Va}\left(\mathrm{R}_{1}=\mathrm{R}_{2}=\mathrm{OtBu}\right)$

Figure 3. The bioorganometallics III, IV and Va that contain turn-inducing ferrocene scaffolds.

availability), ferrocenes have attracted much attention in the field of medicinal organometallic chemistry termed also as bioorganometallic chemistry. ${ }^{[8]}$ Ferrocene compounds have been intensively explored for medical purposes, ${ }^{[8]}$ esspecially in anticancer ${ }^{[9,10]}$ and antimicrobial studies. Among numerous ferrocene compounds tested for their anticancer activity, the particular attention has been paid to antiproliferative effect of ferrocenyl tamoxifen analogue named ferrocifen, on breast cancer cells. ${ }^{[11]}$ The antitumor activity of various bioferrocenes such as ferrocenyl alkyl nucleobases, ${ }^{[12]}$ azalactone ferrocene, ${ }^{[13]}$ ferrocenyl conjugates with salts of $\mathrm{N}$-alkylpyridinium $^{[14]}$ and carbohydrate ferrocene conjugates ${ }^{[15]}$ was also examined. The initial researches of antimicrobial effects of ferrocenes began with ferrocene modified penicillins, cephalosporins and rifamycin, ${ }^{[16-19]}$ and continued with derivatives containing various pharmacophore groups ${ }^{[20]}$ and structural fragments of biomolecules, such as amino acids, peptides, sugars, nucleobases and steroids. ${ }^{[21,22]}$

Considering the biological significance of ferrocenemodified biomolecules, ${ }^{[11,23-27]}$ the joint research on the mannoside inhibitors of hemagglutination la- $\mathbf{c}^{[28]}$ and Ila $-\mathbf{c}^{[29]}$ that contain ferrocene moiety in aglycon has been started in Rapić and Tomić groups (Figure 2). Since the urinary tract infections are mostly caused by adhesion of uropathogenic Escherichia coli on mannose units of a membrane glycoprotein that is expressed on superficial epithelial cells of the urinary tract, ${ }^{[30]}$ the development of antiadhesion therapeutics aimed to prevent Escherichia coli lectin FimH-mediated adhesion has become a focus of researches in the last 50 years. The chemical synthesis of mannose-containing antiadhesives involves the insertion of lipophilic alkyl or aromatic groups to the aglycon part, ${ }^{[31]}$ resulting in a dramatic increment of their affinity for FimH.
Therefore, the significant increment of the inhibitory activity of conjugate llc in comparison to conjugates la-c and lla,b was in accordance with the enhanced inhibitory activity of the mannosides with elongated alkyl chains. [31]

Furthermore, the conjugates of ferrocene and amino acids have been extensively studied in the field of peptidomimetics. 1,1'-Disubstituted ferrocene scaffolds, equipped with hydrogen bonding functionalities, have been employed for almost 20 years to nucleate turns and $\beta$-sheet-like structures in short peptides. ${ }^{[32-37]}$ The two cyclopentadienyl rings in ferrocene have a distance of $\sim 3.3 \AA$ which corresponds to the space between hydrogen bonding donor and acceptor sites in $\beta$-sheets. Thereby, the introduction of the peptide chains into the ferrocene scaffold brings them to adequate distance to allow their communication through intramolecular hydrogen bonding required for 3D structure formation and function of biological systems. ${ }^{[38]}$ The hydrogen bond donating/accepting properties of turn-inducing ferrocene scaffolds determine the hydrogen bonding patterning of the derived peptides: the tenmembered interstrand hydrogen-bonded rings ( $\beta$-turn-like) were established in the conjugates of the amino acids or peptides with dicarbonyl-functionalized ferrocene core (III), [32] the twelve-membered rings were formed in their conjugates with -NH-Fn-CO- moiety (IV, Fn = ferrocenylene), ${ }^{[33]}$ while conjugation with diamino-functionalized ferrocene lead to the fourteen-membered hydrogen-bonded rings [also labelled as two simultaneous ten-membered rings ( $\beta$-turn-like)] in the corresponding conjugates $\mathrm{Va}^{[34]}$ (Figure 3).

The overview of the previously reported peptides IV was given by Rapić. ${ }^{[39]}$

In this contribution, the review of authors recent research results on ferrocene (bio)conjugates is given. The 
first part of the paper is concerned on potential biologically active ferrocene conjugates with resveratrol and mannose. The second part of the paper is dealing with conformational behaviour of ferrocene peptidomimetics studied by means of spectroscopic methods and DFT calculations.

\section{I.}

\section{SYNTHESIS AND BIOLOGICAL EVALUATION OF FERROCENE CONJUGATES WITH RESEVERATROL AND MANNOSE}

\section{Ferrocene-resveratrol Conjugate 2}

Resveratrol [3,5,4'-trihydroxystilbene (RSV) (Figure 4a)] is well-known to promote cardioprotection, cancer prevention and therapy, immune regulation and metabolic and neuroprotective functions. ${ }^{[40-42]}$ The approaches for improving its biological profile include modification of the number and position of the aromatic groups, insertion of a long alkyl chains or functionalized chains and the addition of acyl chains to free hydroxyl groups. ${ }^{[43]}$ VervandierFasseur et al. applied the first approach to prepare ferrocene-containing RSV-derivative VI that was found to exibit more than 10-fold higher inhibitory activity in primary human colon carcinoma cells (SW480) and hepatoblastoma (HepG2) cell lines compared to those of RSV (Figure 4b). ${ }^{[44]}$

Encouraged by this result, we have synthesized ferrocene-RSV conjugate $\mathbf{2}$ equipped with trimethylene alkyl chain in order to improve its lipophilicity as a crucial requirement for biological activity. ${ }^{[45]}$ The conjugate $\mathbf{2}$ was obtained by esterification ${ }^{[46]}$ of ferrocene butyric acid (1) with $\mathrm{C} 3-\mathrm{OH}$ group of trans-RSV in the presence of DMAP, $\mathrm{NEt}_{3}$ and $\mathrm{Boc}_{2} \mathrm{O}$ (Scheme 1 ) and its inhibitory potential on HepG2 and normal ovary cells (CHO-K1) proliferation was evaluated.

The results of cytotoxicity evaluation revealed profound effects in biological activity of ferrocene-RSV conjugate $\mathbf{2}$ vs. RSV in HepG2 cell line (Figure 5). Accordingly, IC $C_{50}$ value for $\mathbf{2}$ was $20 \%$ lower than $\mathrm{IC}_{50}$ value for RSV. Much lower cytotoxicity on normal CHO-K1 cells was observed. In spite of the decreased activity in comparison to the previously reported conjugate $\mathbf{V}\left[{ }^{[44]}\right.$, our conjugate $\mathbf{2}$ was more potent than RSV and therefore indicated the potential for further studies on ferroceneRSV conjugates that are in progress in our group.

\section{Ferrocene-mannose Conjugates $10,11,14$ and 15}

The improved biological activity of the previously reported conjugate IIc ${ }^{[29]}$ was attributed to the elongation of the alkyl spacer incorporated between ferrocene core and chiral linker. Besides the elongated aglycon alkyl chain, ${ }^{[47]}$ the two structural elements - mannose moiety and hydrophobic aglycon residue - are required to achieve the antiadhesion effect. Considering these findings, we were prompted to determine if the further elongation of the alkyl chain from propyl to pentyl in bioorganometallics 10, 11, 14 and 15 will contribute to their pronounced inhibitory effect. ${ }^{[48]}$ The novel bioconjugates were designed to contain ester $(\mathbf{1 0}, \mathbf{1 1})$ or amide linkage $(\mathbf{1 4}, \mathbf{1 5})$ between (a)<smiles>Oc1ccc(/C=C/c2cc(O)cc(O)c2)cc1</smiles>

(b)<smiles>[R]Oc1ccc(/C=C/c2ccccc2)cc1</smiles>

\section{$\mathrm{Fe}$}

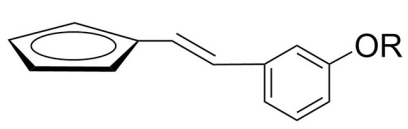<smiles>Cc1ccc(C(=O)C#[W])cc1</smiles>

Figure 4. The chemical structures of (a) resveratrol (RSV) and (b) ferrocene-RSV analog VI.

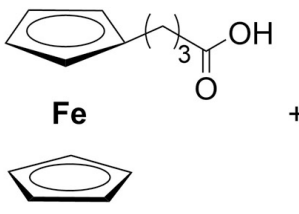

1

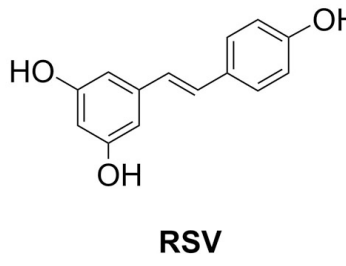

2. $\mathrm{NEt}_{3}$

3. $\mathrm{Boc}_{2} \mathrm{O}$

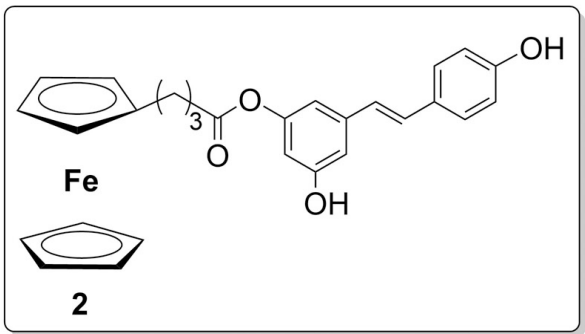

Scheme 1 . Synthesis of ferrocene-RSV conjugate 2. 

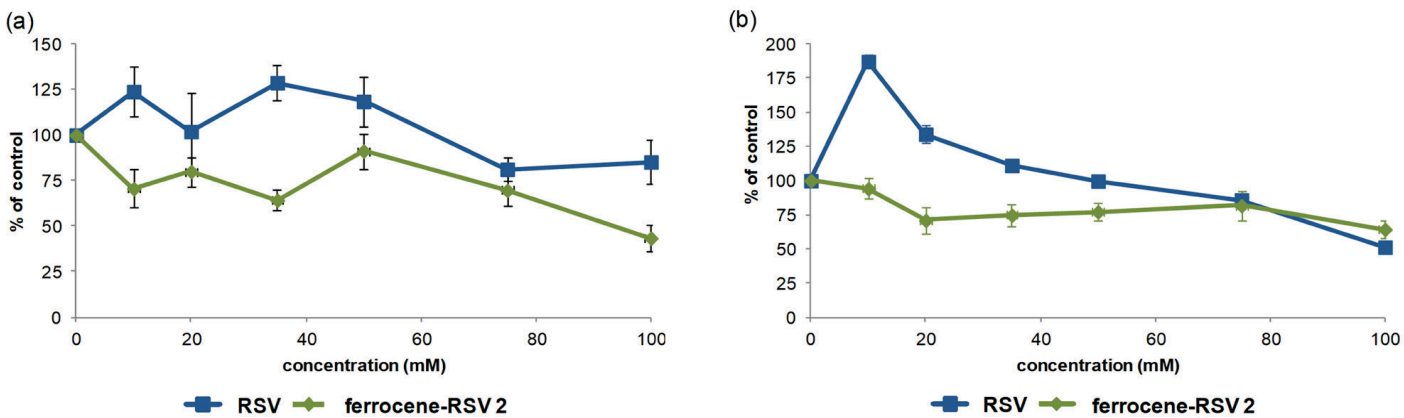

Figure 5. In vitro anti-proliferative effect of RSV and ferrocene-RSV conjugate 2 against (a) hepatoblastoma (HepG2) cells and (b) normal ovary cells (CHO-K1).

mannose and ferrocene in order to obtain a set of compounds that enables the more precise evaluation of the structural requirements for higher binding affinity of ferrocene-containing inhibitors of hemagglutination.

The condensation of the organometallic moieties with mannopyranoside acid was realized through ester and amide bonding, respectively (Scheme 2 ). The esterification of the mannopyranoside acid $\mathbf{7} \boldsymbol{\alpha}, \boldsymbol{\beta}$ with ferrocene alcohols $\mathbf{3}$ and $\mathbf{4}$ in the presence of stoichiometric amount of $\mathrm{Boc}_{2} \mathrm{O}$ and catalytic amount of DMAP gave $O$-protected ester conjugates $\mathbf{8} \alpha, \boldsymbol{\beta}$ and $\mathbf{9} \alpha, \boldsymbol{\beta}$. The synthetic pathway to obtain amide conjugates $12 \alpha, \beta$ and $13 \alpha, \beta$ started by Bocdeprotection of carbamates $\mathbf{5}$ and $\mathbf{6}$ in acidic milieu. The obtained hydrochloride salts were treated with an excess of $\mathrm{NEt}_{3}$ to liberate free amines available for coupling with previously activated acid $\boldsymbol{7} \boldsymbol{\alpha}, \boldsymbol{\beta}$ to give $\boldsymbol{O}$-protected amides $14 \alpha, \beta$ and $15 \alpha, \beta$. Considering the $\alpha$-anomeric preference of bacterial lectin $\mathrm{FimH}$, the anomeric mixtures of the synthesized bioconjugates were separated by preparative thin layer chromatography and $\alpha$-anomers of ferrocene conjugates with mannose were subjected to debenzylation to give goal compounds $10 \alpha, 11 \alpha, 14 \alpha$ and $15 \alpha$. The next step was to evaluate the minimal concentration of the synthesized bioconjugates required to prevent FimHmediated agglutination of guinea-pig erythrocytes, that was expressed as inhibition titer (IT) and compared to those of a reference inhibitor, methyl $\alpha$-D-mannoside (MeMan) to give relative IT (RIT). Although we have already observed that the elongation of the alkyl chain in compound IIc was accompanied with the increment of the inhibitory activity, ${ }^{[29]}$ the herein obtained results revealed that the alkyl chain length is not of decisive importance for FimHmediated binding of the investigated ferrocenes $10 \alpha, 11 \alpha$, $14 \alpha$ and $15 \alpha$. Since the compound $15 \alpha$ displayed 2 -fold increment of inhibitory activity in comparison with herein studied compounds and 14-fold increment in comparison to standard MeMan (Figure 6), it is more likely that replacement of an ester linkage in $\mathbf{1 0 \alpha}$ with amide linkage in $15 \alpha$ (both containing butyl spacer between ferrocene

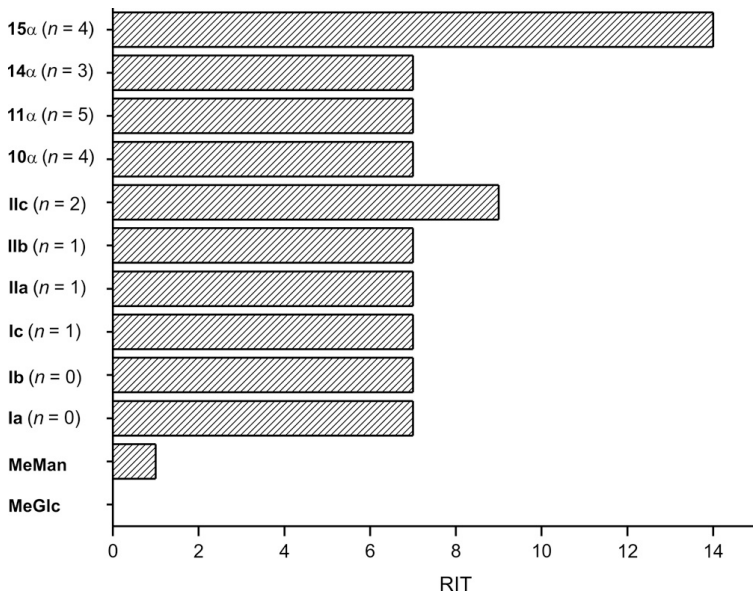

Figure 6. Inhibition of hemagglutination of guinea-pig erythrocytes by type 1 fimbriated E. coli HB101 (pPKI4).

moiety and linkage) strongly influences the inhibitory potential.

Our ongoing research is directed to explore if the aromatic modification of the most potent FimH antagonist $15 \alpha$ will improve lipophilicity and binding affinity in the hydrophobic cavity of the mannose binding site of FimH, founded to be flanked with aromatic tyrosine residues.

II.

\section{CONFORMATIONAL PROPERTIES OF FERROCENE PEPTIDOMIMETICS}

\section{Oxalamide-bridged Ferrocene 17}

Peptides experience serious challenges (low metabolic stability towards proteolysis, the poor membrane permeability and the interactions with undesired receptors due to their conformational flexibility) on their way to become applicable for medicinal purposes. These obstacles can be overcome by using peptidomimetics. ${ }^{[49,50]}$ Among the numerous approaches in the design and synthesis of 


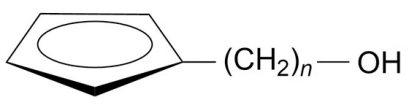

$\mathrm{Fe}$

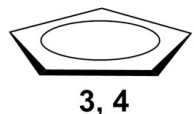

$\mathrm{Boc}_{2} \mathrm{O}, \mathrm{DMAP}$

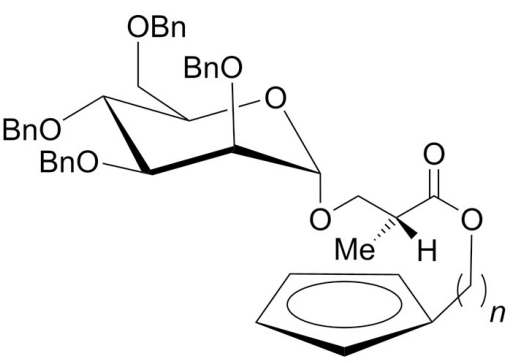

$\mathrm{Fe}$

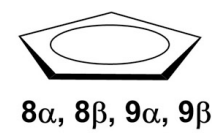

TLC-separation of anomers

$\mathrm{H}_{2} / \mathrm{Pd}$

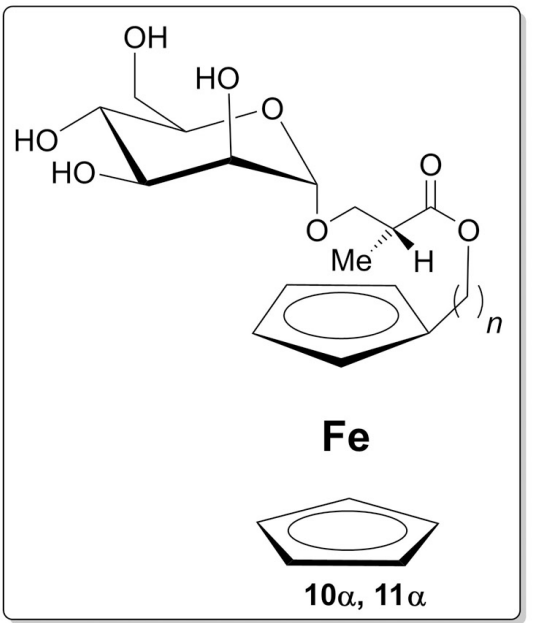

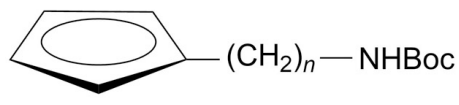

$\mathrm{Fe}$

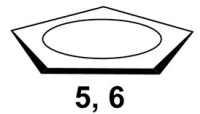

1. HClgaseous

2. $\mathrm{NEt}_{3}$

3. EDC, HOBt

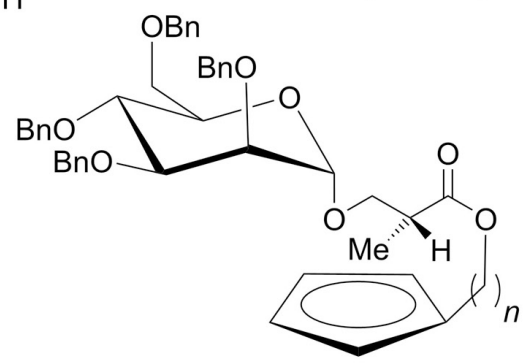

$\mathrm{Fe}$

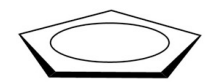

$12 \alpha, 12 \beta, 13 \alpha, 13 \beta$

TLC-separation of anomers

$\mathrm{H}_{2} / \mathrm{Pd}$

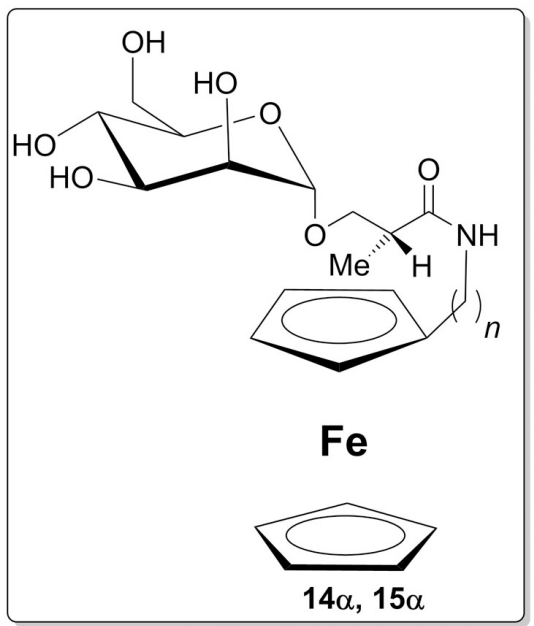

5, 1214

$n=3$

$3,6,16,10,13,15 ; n=4$

4, 9, 11;

$n=5$

Scheme 2. Synthesis of mannose-ferrocene conjugates 10, 11, 14 and 15 . 
peptidomimetics, the replacement of the peptide bond with other chemical groups ${ }^{[51]}$ or partially retro or retroinverso modifications ${ }^{[52,53]}$ has been drawing attention. The retro-peptides, including oxalamide based retro-peptides, represent a valuable class of peptidomimetics owing to their improved proteolytic stability and bioavailability in comparison to the original peptides. Besides their application in bioorganic and medicinal chemistry ${ }^{[54]}$ as anticancer agents, ${ }^{[55-57]}$ antimalarial agents, ${ }^{[58]}$ and inhibitors against Alzheimer's disease ${ }^{[59]}$ and HIV-1, ${ }^{[60]}$ the oxalamide moities were used in engineering and crystal design, ${ }^{[61]}$ in coordination chemistry as ligands ${ }^{[62]}$ and in organogels formation. ${ }^{[63]}$

The extensive work of Žinić and co-workers on oxalyl-retro peptides gelators ${ }^{[63]}$ revealed that intramolecular hydrogen bonds determine the conformation, while intermolecular hydrogen bonding is mostly responsible for supramolecular organization of the oxalamides. ${ }^{[64-66]}$

With this in mind, we have synthesized oxalamidebridged ferrocene 17 (Scheme 3), and have tested its cytotoxic and gelation potential. ${ }^{[67]}$ Boc-deprotection of compound $\mathbf{1 6}$ in the presence of gaseous $\mathrm{HCl}$, followed by treatment of the hydrochloride salt with $\mathrm{NEt}_{3}$ gave free amine. The addition of oxalyl-chloride enabled the bridging of the two ferrocene moieties by oxalamide unit.

Considering that gelation is governed by hydrogen bonding, we took IR and NMR spectroscopic studies in

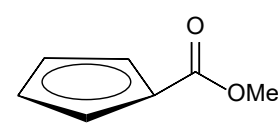

$\mathrm{Fe}$

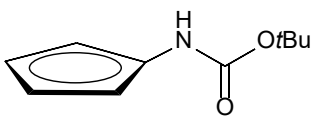

16

$$
\mid \begin{aligned}
& \text { 1. } \mathrm{HCl}_{\text {gaseous }} \\
& \text { 2. } \mathrm{NEt}_{3} \\
& \text { 3. }(\mathrm{COCl})_{2}
\end{aligned}
$$

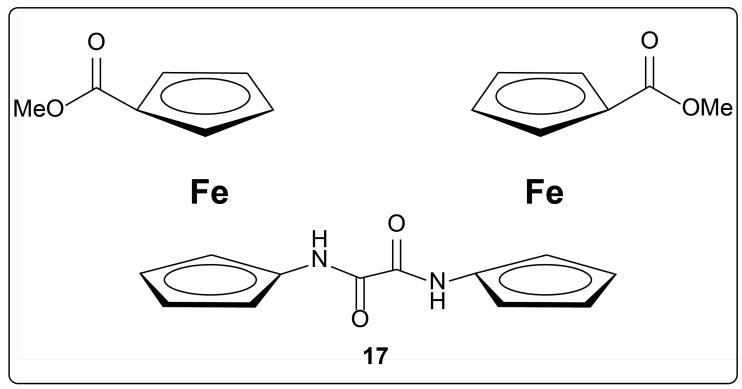

Scheme 3. Synthesis of oxalamide-bridged ferrocene 17.

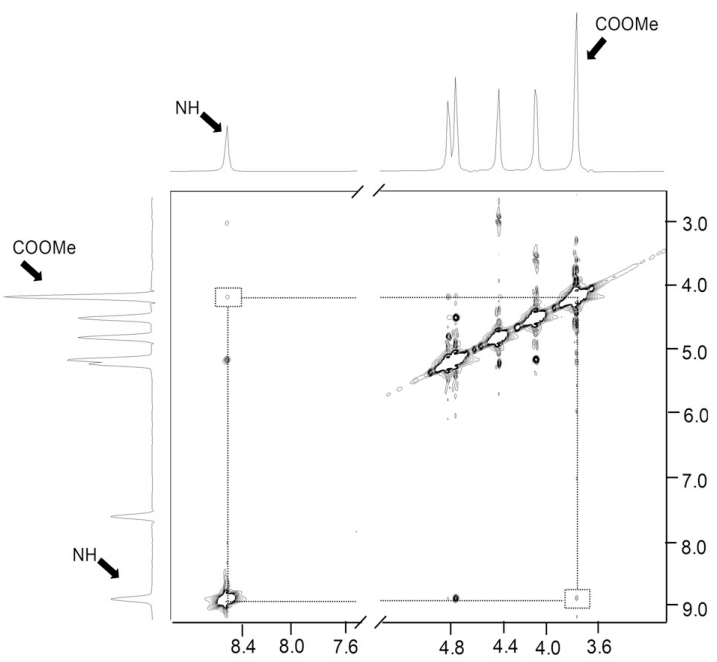

Figure 7. The NOE connectivity between $\mathrm{NH}_{\mathrm{Fn}}$ and $\mathrm{Me}_{\text {coome }}$ of oxalamide-bridged ferrocene 17.

order to elucidate the hydrogen bonding behaviour of the compound 17. The involvement of amide protons in hydrogen bonds is implied by red shifted $\mathrm{NH}$ stretching vibrational frequencies observed at $3369 \mathrm{~cm}^{-1}$ and corroborated by their downfield shift $(\delta=8.56 \mathrm{ppm})$ in nonpolar $\mathrm{CDCl}_{3}$. The nature of the hydrogen bonding was tentatively deduced by measuring concentrationdependent IR and NMR spectra. Since IR absorption frequency and $\mathrm{NH}$ chemical shift were almost preserved upon dilution, the intramolecular nature of the associated $\mathrm{NH}$ groups was strongly suggested and endorsed by the negligible dependence of the chemical shifts on temperature. Thereat, the NOE contact between $\mathrm{NH}_{\mathrm{Fn}}$ and Mecoome might account for conformational pattern based on $\mathrm{NH}_{\mathrm{Fn}} \cdots \mathrm{OC}_{\text {COOMe }}$ intramolecular hydrogen bonds (IHBs) (Figure 7).

In the crystal packing of oxalamide 17, determined by single-crystal X-ray diffraction analysis, molecules were not connected by the two $\mathrm{N}-\mathrm{H} \cdots \mathrm{O}$ hydrogen bonds as it is common for the central oxalamide bridge. Instead, two neighbouring molecules were connected by only one $\mathrm{N}-\mathrm{H} \cdots \mathrm{O}$ hydrogen bond and two weaker $\mathrm{C}-\mathrm{H} \cdots \mathrm{O}$ hydrogen bonds (Figure $8 \mathrm{a}$ ). In this way molecules made a staircase-like pattern (Figure 8b).

Next, the capacity of oxalamide $\mathbf{2}$ to form gels with water and a series of common organic solvents $(\mathrm{EtOH}, \mathrm{THF}$, $\mathrm{CH}_{3} \mathrm{CN}$, acetone, $\mathrm{AcOEt}, \mathrm{CH}_{2} \mathrm{Cl}_{2}$, toluene, $p$-xylene, decaline, tetraline) and solvents mixture (DMSO- $\mathrm{H}_{2} \mathrm{O}, \mathrm{DMF}-\mathrm{H}_{2} \mathrm{O}$ ) of different polarity was investigated. Instead of gelation only the crystallization of compound $\mathbf{1 7}$ occurred, despite the fact that all the necessary conditions for gelation ${ }^{[68]}$ [an appropriate solubility, the presence of hydrophilic (oxalamide) unit and hydrophobic (ferrocene) moiety] were met. Since the tested compound did not exhibit any gelation ability, we are currently working on its analogues as the potential gelators. 

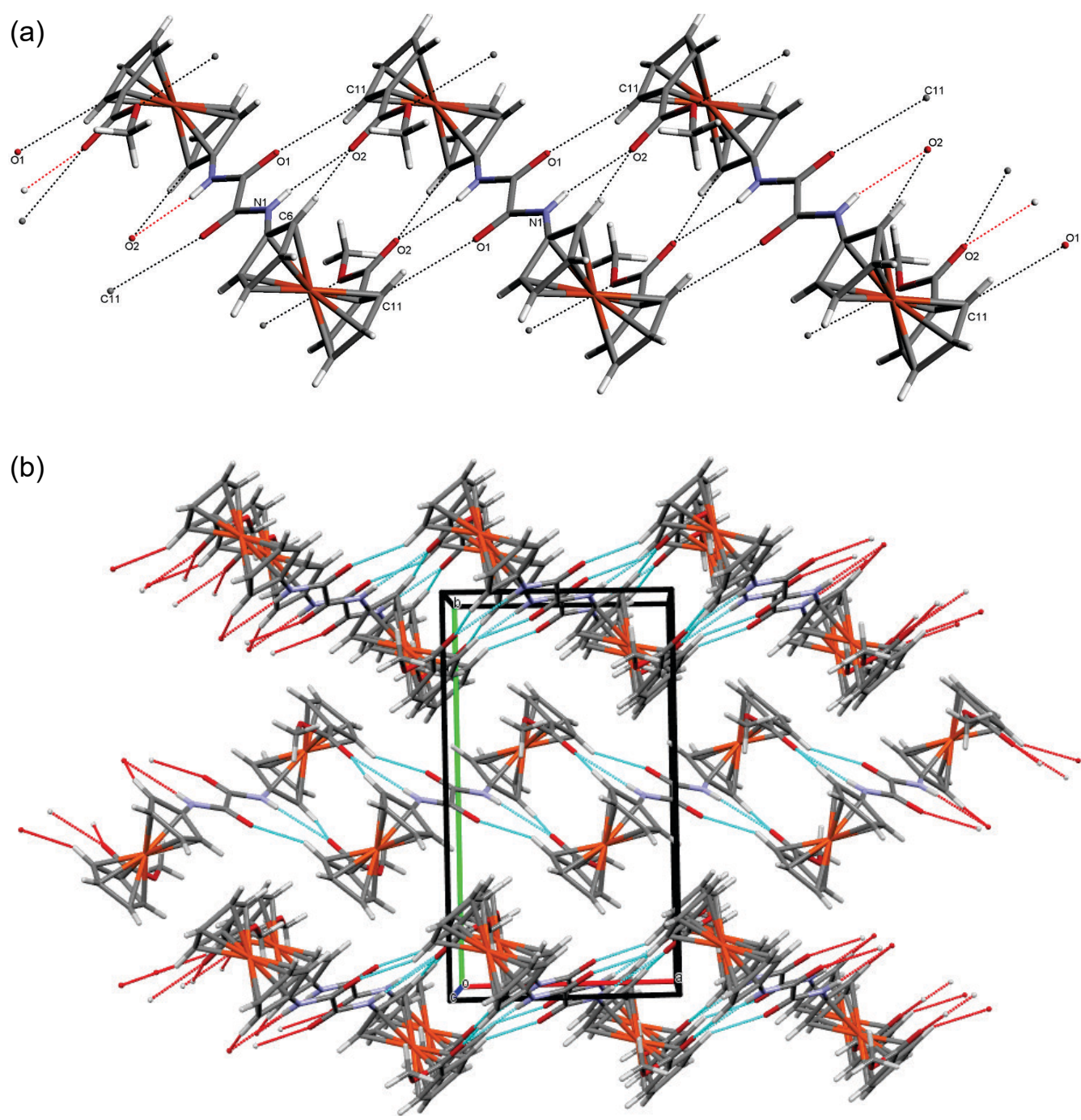

Figure 8. Crystal packing of oxalamide 17. (a) Two $\mathrm{C}-\mathrm{H} \cdots \mathrm{O}$ and one $\mathrm{N}-\mathrm{H} \cdots \mathrm{O}$ hydrogen bonds connect the neighbouring molecules. (b) View along the $c$ axis reveals that the crystal packing is realized by stacking of the hydrogen bonded staircase patterns.

In vitro screening of oxalamide 17 revealed proliferative as well as cytotoxic effect on normal human embryonic kidney cells (HEK293T) and tumour HepG2 cells (Figure 9). The observed dual effect of oxalamide $\mathbf{1 7}$ is attributed to the biological phenomenon named hormesis, that is characterised by a low dose stimulation or beneficial effect and high-dose inhibition or toxic effect. ${ }^{[69-70]}$ Biphasic dose-response effect had not been reported for ferrocenes yet. The cytotoxic i.e. antiproliferative activity of the oxalamide-bridged ferrocene 17 on the normal HEK293T cell line was weaker than in HeLa cancer cell line, whilst the displayed proliferative effect was most pronounced on normal HEK293T cells, and was not observed in tumour HeLa cells. These findings implicated the therapeutic potential of oxalamide-bridged ferrocene $\mathbf{1 7}$, either as an anticancer agent, or as a stimulator of cell growth.

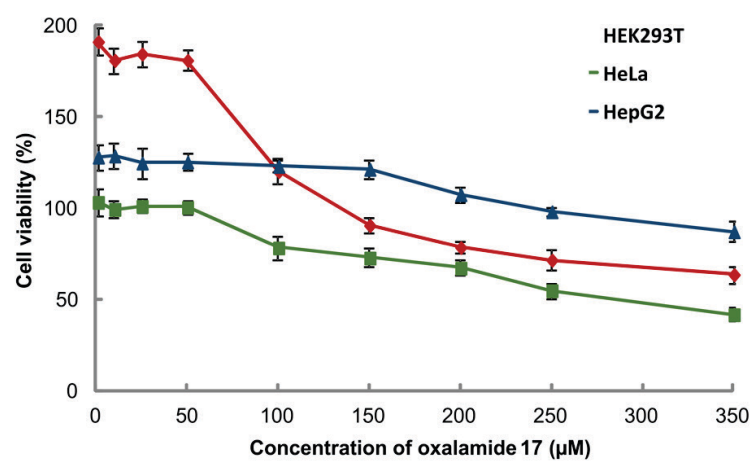

Figure 9. Effect of oxalamide-bridged ferrocene 17 on HEK293T, HeLa and HepG2 cell viability. The lines connecting the measured points are drawn to enhance clarity. 

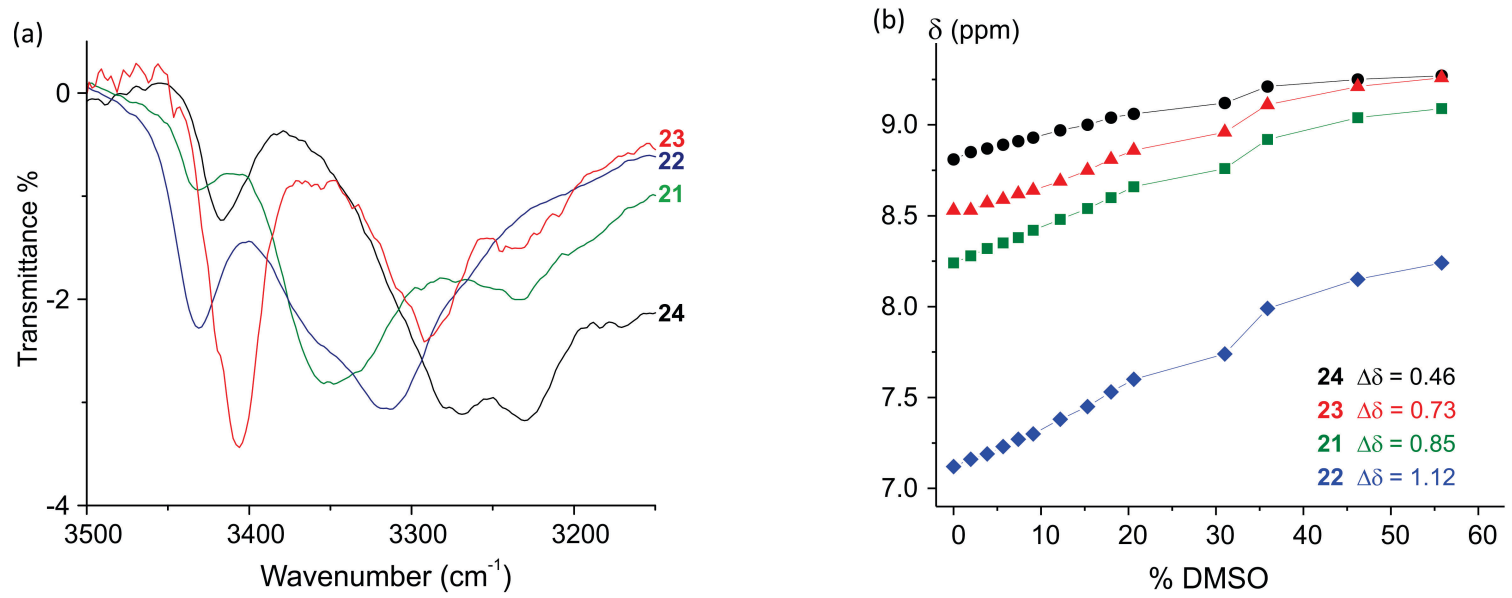

Figure 10. (a) The $\mathrm{NH}$ stretching vibrations in concentration-dependent IR spectra of 21-24 in $\mathrm{CH}_{2} \mathrm{Cl}_{2}\left(c=5 \times 10^{-2} \mathrm{M}\right)$, (b) Solvent dependence of $\mathrm{NH}$ chemical shifts at varying concentrations of $d_{6}$-DMSO in $\mathrm{CDCl}_{3}\left(c=2.5 \times 10^{-2} \mathrm{M}\right.$, 298 K) to probe exposed vs. hydrogen-bonded amides.

\section{Bioconjugates of 1'-Aminoferrocene-1- carboxylic Acid and Proline 21-24}

Besides its ability to induce turn structures when incorporated in peptides, ${ }^{[71-73]}$ proline undergoes cis-trans isomerization, a process that regulates numerous biological events such as cellular uptake, oligomerization, folding and catalysis. Therefore, in continuation of our work on ferrocene peptides IV we were interested to determine the impact of proline unit on conformational and biological properties of the bioorganometallics 21-24. ${ }^{74]}$

Ac-NH-Fn-CO-Pro-OMe (21) and Boc-NH-Fn-COPro-OMe (22) were prepared by coupling of $N$-protected $1^{\prime}$ aminoferrocene-1-carboxylic acid (19/20) with $C$-protected proline following the above described coupling procedure. Boc-Pro-NH-Fn-COOMe (23) and Ac-Pro-NH-Fn-COOMe (24), with an exchanged sequence of constituent amino acid relative to $\mathbf{2 1}$ and 22, were prepared from Boc-NH-FnCOOMe (16). Upon Boc-deprotection and coupling with activated Boc-Pro-OH the goal compound $\mathbf{2 3}$ was obtained. Its Boc-group was transfered to Ac giving Ac-Pro-NH-FnCOOMe (24) (Scheme 4).

Proline-containing bioconjugates 21-24 were subjected to standard spectroscopic methods (IR, NMR and CD spectroscopy) to explore their conformational behaviour. The amide stretching regions of the IR spectra indicated the presence of both associated (bellow $3400 \mathrm{~cm}^{-1}$ ) and free states (above $3400 \mathrm{~cm}^{-1}$ ). It is evident from the Figure 10a that (i) the population of hydrogen-bonded $\mathrm{NH}$ groups of peptides 21, 22 and $\mathbf{2 4}$ is increased in comparison to peptide 23, and (ii) the intensities of hydrogen-bonded $\mathrm{NH}$ absorption bands of analogues 21-24 in relation to their free $\mathrm{NH}$ band depended on the employed blocking group. Thereat, the reduced content of the associated NH bands was observed for peptides $\mathbf{2 2}$ and $\mathbf{2 3}$, due to the steric hindrance imparted by bulky Boc groups. To access whether the hydrogen-bonded $\mathrm{NH}$ groups were engaged in intra- or intermolecular manner, the concentration dependence of $\mathrm{NH}$ absorption bands was tested. The unchanged ratio of the associated and free $\mathrm{NH}$ bands upon successive dilution suggested the intramolecular employment of $\mathrm{NH}$ groups.

Hydrogen-bonding behaviour of bioconjugates 21-24, predicted by IR data, was corroborated by the downfield shifts $(\delta>7 \mathrm{ppm})$ of their $\mathrm{NH}$ groups in non-polar $\mathrm{CDCl}_{3}$. The almost preserved amide chemical shifts upon dilution from $50 \mathrm{mM}$ to $6.25 \mathrm{mM}$ or heating from $258 \mathrm{~K}$ to $328 \mathrm{~K}$ strongly support the intramolecular hydrogen bonding patterning, suggested by concentration-independent IR measurements. In order to evaluate the strength of IHBs, DMSO titration experiments were carried out (Figure 10b). The most downfield shifted $\mathrm{NH}_{\text {Fa }}$ of $\mathbf{2 4}$ exhibited the lowest sensitivity to DMSO and therefore was considered to be involved in a strong IHB. More pronounced changes of amide shifts in the presence of DMSO were observed for $\mathbf{2 1}$ and $\mathbf{2 3}$, indicating their engagement in IHBs of medium strength. Since the most upfield shifted $\mathrm{NH}_{\mathrm{Fn}}$ of $\mathbf{2 2}$ was found to be the most DMSO-sensitive, its participation in a weak IHB was suggested.

The NMR data obtained upon heating or DMSO titration revealed cis/trans isomerization of proline peptide bonds. The complete coalescence of the two peaks that correspond to cis and trans isomers occurred upon heating from $258 \mathrm{~K}$ to $328 \mathrm{~K}$ due to the medium (23) and rapid (21, 22 and 24) isomerization. The abundance of trans amide in peptide $\mathbf{2 4}$ upon titration with DMSO corroborated the assumption of its involvement in strong IHB that induced the isomer locking, while the complete coalescence of amide resonances of peptide $\mathbf{2 2}$ was caused by engagement of $\mathrm{NH}$ group in weak $\mathrm{IHB}$, as it was suggested by its pronounced upfield shifting in the presence of DMSO. 
<smiles>[Y]C(=O)Nc1ccccc1</smiles>

$\mathrm{Fe}$<smiles>COC(=O)c1ccccc1</smiles>

$16(\mathrm{Y}=\mathrm{OtBu})$

$18(Y=M e)$

$\mathrm{NaOH} / \mathrm{H}_{2} \mathrm{O}, \mathrm{MeOH}$<smiles>[Y]C(=O)Nc1ccccc1</smiles>

$\mathrm{Fe}$<smiles>O=C(O)c1ccccc1</smiles>

$19(\mathrm{Y}=\mathrm{Me})$

$20(\mathrm{Y}=\mathrm{O} t \mathrm{Bu})$
1. HClgaseous

2. $\mathrm{Et}_{3} \mathrm{~N}$

3. Boc-Pro-OH/ EDC, HOBt $(\mathrm{Y}=\mathrm{O} t \mathrm{Bu})$<smiles>CCCCOC(=O)N1CCCC1C(=O)Nc1ccccc1</smiles>

Fe

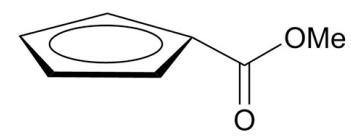

23

HClgaseous

2. $\mathrm{Et}_{3} \mathrm{~N}$

3. $\mathrm{AcCl}$

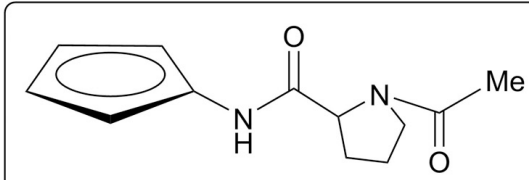

$\mathrm{Fe}$

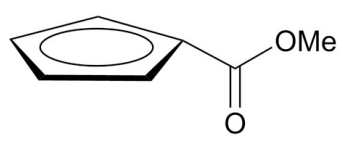

24
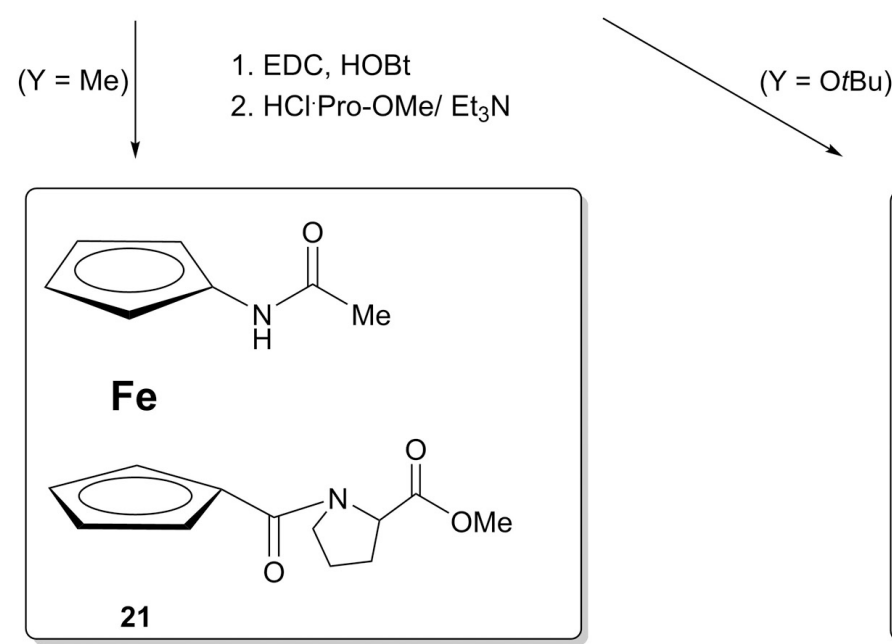

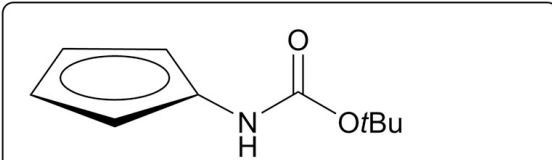

$\mathrm{Fe}$

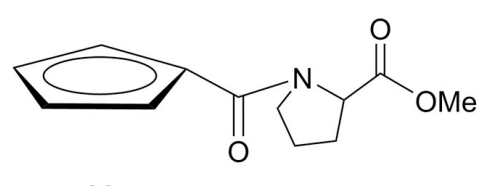

Scheme 4. Synthesis of bioconjugates 21-24.

The IHB patterning of peptides 21-24, proposed by IR and ${ }^{1} \mathrm{H}$ NMR data, was strongly supported by NOE spectroscopy. The interstrand NOE contacts $\mathrm{NH}_{\mathrm{Fn}} \rightarrow \mathrm{CH} \alpha_{\text {Pro }}$ and $\mathrm{NH}_{\mathrm{Fn}} \rightarrow \mathrm{Me}_{\text {Coome }}$ accounts for $\mathrm{NH}_{\mathrm{Fn}} \cdots \mathrm{OC}_{\text {Pro }} \mathrm{IHB}$ in peptides $\mathbf{2 1}$ and 22, while intrastrand NOE contacts of $\mathrm{NH}_{F n}$ with $\mathrm{N}$ - terminal protons of $\mathbf{2 3}$ and $\mathbf{2 4}$ point to $\mathrm{NH}_{\mathrm{Fn}} \cdots \mathrm{OC}_{\text {Pro }} \mathrm{IHB}$ (7membered $\gamma$-turn) (Figure 11).

The previous work on ferrocene-containing peptides revealed that the insertion of ferrocene chromophore $(\lambda \sim$ $480 \mathrm{~nm}$ ) into the chiral peptide environment enables 

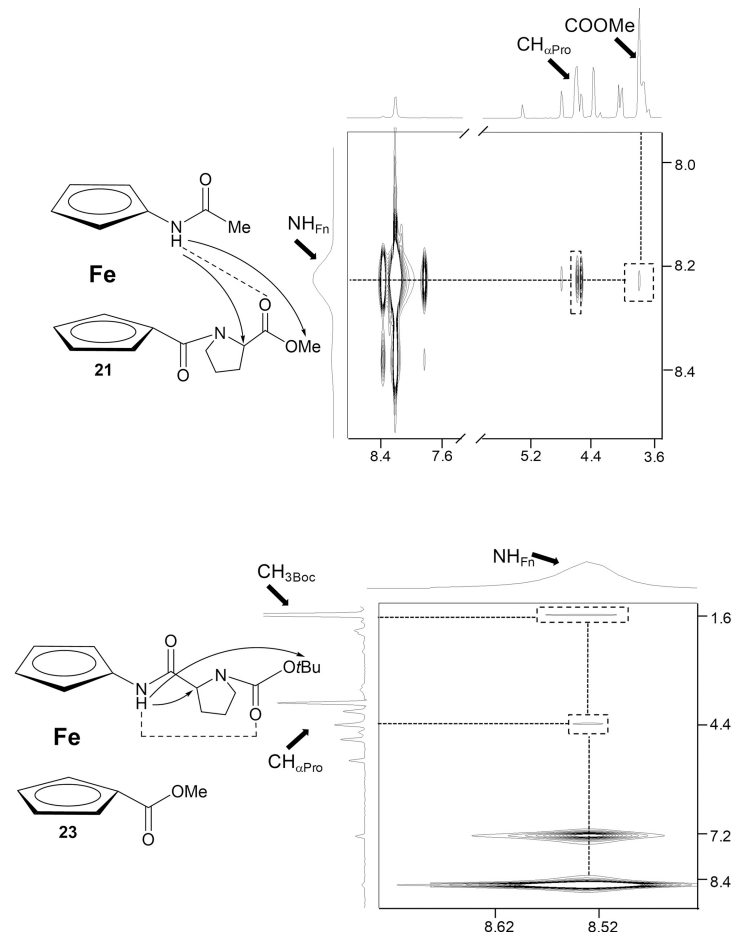

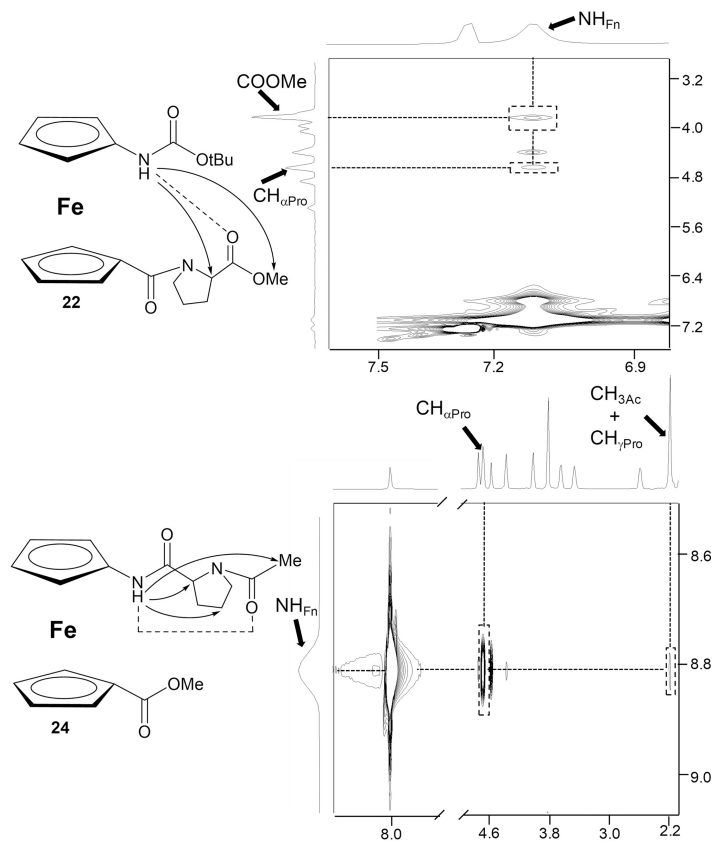

Figure 11. The interchain NOE connectivities between the $\mathrm{C}$ - and N-termini of 21 and 22 and the intrachain NOE connectivities of 23 and $\mathbf{2 4}$ (the proposed IHBs are depicted with dashed lines).

hydrogen bonding between podand peptide chains. Conformational changes, promoted by insertion of organometallic template into peptide chain, lead to the adoption of ordered structures that induce Cotton effect in ferrocene region.

The absolute values of Cotton effects of 21-24, ranged between 500 and 1000 deg cm $\mathrm{dmol}^{-1}$ corresponded to those observed for their alanine analogues, ${ }^{[33 \mathrm{~b}]}$ indicating the presence of an ordered structures in $\mathrm{CH}_{2} \mathrm{Cl}_{2}$ (Figure 12). To address the assumption that peptide 22 was involved in the weakest IHB in comparison to peptides $\mathbf{2 1}, \mathbf{2 3}$ and $\mathbf{2 4}$, their CD activity in the presence of DMSO was tested. As expected, the absence of Cotton effect was observed for peptide 22, due to the cleavage of weak IHB and loss of chiral organization.

The intrastrand hydrogen bond in peptide 23, predicted by NMR study, persisted in the solid state as well. Its conformation was stabilised by one $\mathrm{N}-\mathrm{H} \cdots \mathrm{O}$ and four weak $\mathrm{C}-\mathrm{H} \cdots \mathrm{O}$ intramolecular hydrogen bonds (Figure 13a). An additional stabilization was achieved through interchain dipolar interaction between $\mathrm{CO}_{\mathrm{Fn}}$ and $\mathrm{NH}_{\mathrm{Fn}}$ (Figure 13b).
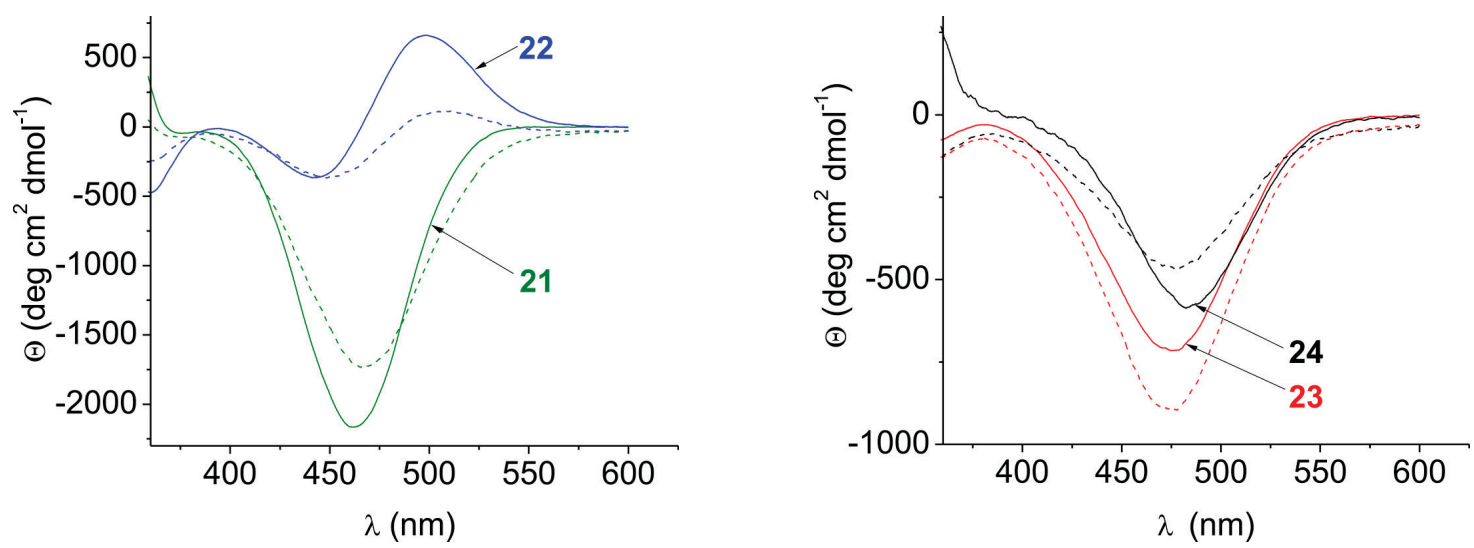

Figure 12. Cotton effects in chirality-organized ferrocene peptides $21-24$ in $\left.\mathrm{CH}_{2} \mathrm{Cl}_{2}\left[(-) c=1 \times 10^{-3} \mathrm{M}\right)\right]$ and $\mathrm{CH}_{2} \mathrm{Cl}_{2}\left(c=1 \times 10^{-}\right.$ 3 M) containing $20 \%$ of DMSO (---). 
(a)

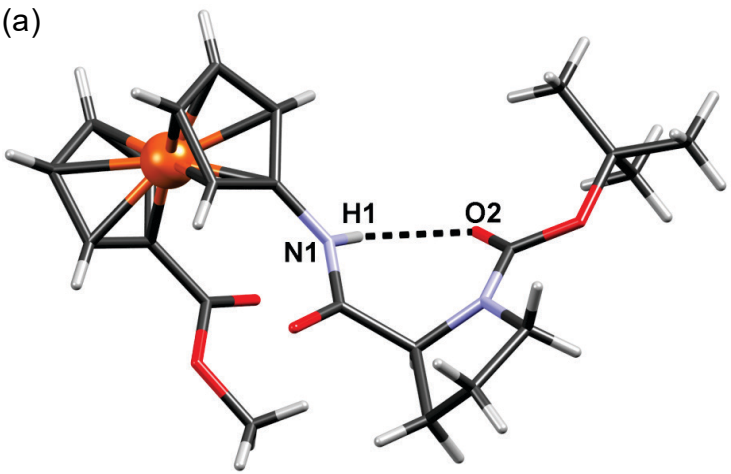

(b)

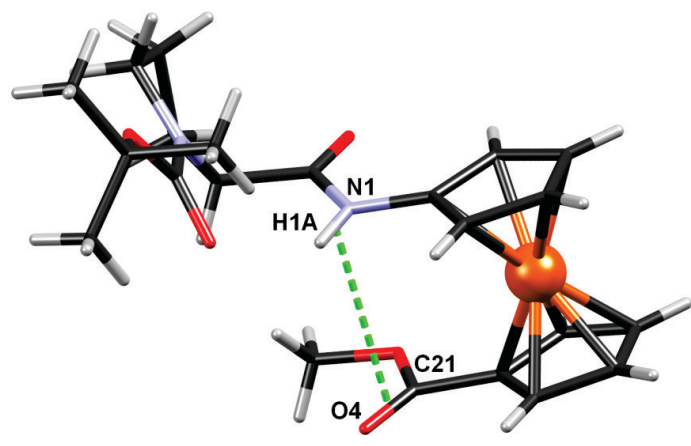

Figure 13. (a) Conformation of Boc-Pro-NH-Fn-COOMe (23) in the crystal stabilised by intrachain 7-membered IHB-ring ( $\psi$-turn), (b) an additional stabilization of Boc-Pro-NH-Fn-COOMe (23) through interchain intramolecular dipolar interaction.
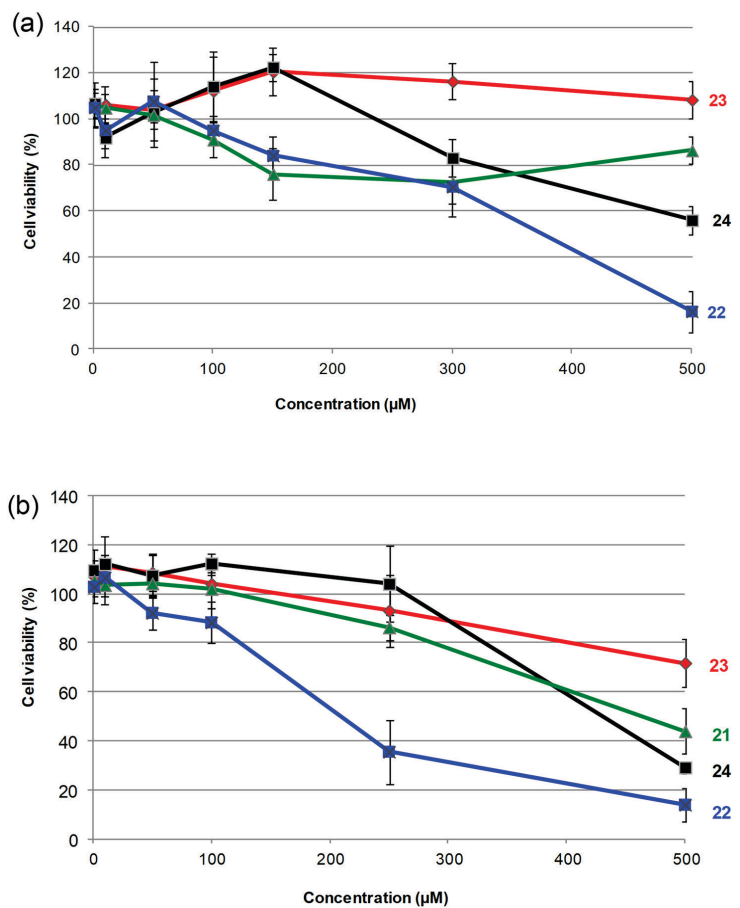

Figure 14. Effects of peptides 21-24 on (a) MCF7 and (b) HeLa cells viability. The lines connecting the measured points are drawn to enhance clarity.

The anticancer potential of peptides 21-24 was tested in vitro and evaluated on the basis of their ability to inhibit growth of MCF7 and HeLa carcinoma cells. While the $50 \%$ inhibition of cell growth was not detected by the compounds 21, 23 and 24, the peptide $\mathbf{2 2}$ exhibited the highest cytotoxicity in MCF7 and HeLa cells (Figure 14). Taking into account the lipophilicity as an important requirement in drug design, the obtained results might be attributed to the increased lipophilicity of peptide $\mathbf{2 2}\left(R_{\mathrm{f}}=\right.$ $0.50)$ in comparison to more polar analogues $21\left(R_{\mathrm{f}}=0.30\right)$, $23\left(R_{\mathrm{f}}=0.33\right)$ and $24\left(R_{\mathrm{f}}=0.22\right)$.

\section{Bioconjugates of 1'-Aminoferrocene-1- carboxylic Acid and Alanine 25-28}

The synthesis of bioconjugates $\mathbf{2 5}^{-28^{[75]}}$ (Scheme 5) has been performed by using the synthetic protocol described above for the preparation of proline-containing ferrocenes, with aim to obtain the simplest models to study the influence of the backbone chirality and terminal group bulkiness on conformational properties of ferrocenecontaining peptides.

The synthesized bioconjugates were subjected to detailed conformational analysis (IR and NMR spectroscopy and DFT study) in order to explore if the replacement of the bulky Boc group with Ac function and L- to D-Ala exchange affects their conformational behaviour.

The ratios of free and associated $\mathrm{NH}$ bands in IR spectra of the examined compounds indicated the increased fraction of hydrogen bonded $\mathrm{NH}$ groups in Acpeptides $\mathbf{2 7}$ and $\mathbf{2 8}$, most likely owing to steric hindrance of Boc groups in $\mathbf{2 5}$ and $\mathbf{2 6}$. Results from the dilution experiments revealed the weakening of the both signals corresponding to free $\left(\sim 3424 \mathrm{~cm}^{-1}\right)$ and bonded $(\sim 3300$ $\mathrm{cm}^{-1}$ ) $\mathrm{NH}$ groups and appearance of a single band slightly shifted to $\sim 3400 \mathrm{~cm}^{-1}$ (Figure 15a), thus disabling reliable determination of the character of association.

The resonances of $\mathrm{NH}_{\mathrm{Fn}}$ groups of peptides 25-28 and $\mathrm{NH}_{\text {Ala }}$ groups of Ac-peptides $\mathbf{2 7}$ and $\mathbf{2 8}$ were observed at downfield region and were therefore expected to be involved in $\mathrm{HB}$. The upfield shifted $\mathrm{NH}_{\text {Ala }}$ groups of Bocpeptides $\mathbf{2 5}$ and $\mathbf{2 6}$ corroborates the assumption that hydrogen bonding was somewhat difficult in the presence of Boc group. To elucidate the possible intramolecular nature of hydrogen bonds, concentration- and temperature-dependent NMR spectra were measured, without expecting any discernible changes in chemical shifts of amide protons engaged in IHBs. The observed negligible dependence of the chemical shifts on concentration and temperature (Figure 15b) strongly 

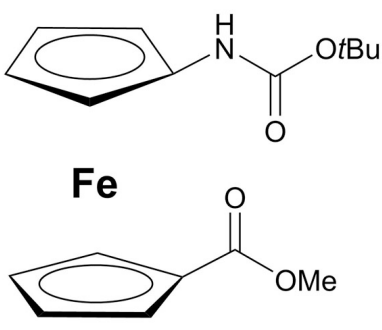

16

1. HClgaseous

2. $\mathrm{Et}_{3} \mathrm{~N}$

Boc-L-Ala-OH/ EDC, HOBt/<smiles>CCCCOC(=O)N[C@@H](C)C(=O)Nc1ccccc1</smiles>

$\mathrm{Fe}$

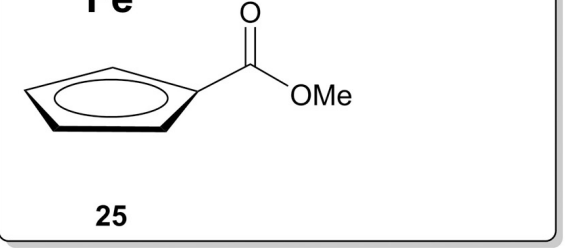

Boc-D-Ala-OH/ EDC, HOBt

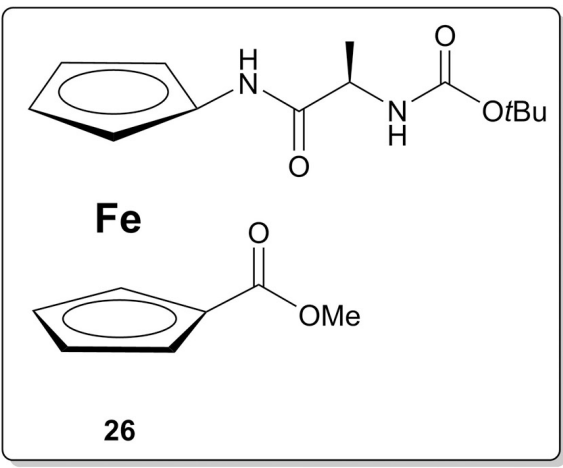

1. HClgaseous

2. $\mathrm{Et}_{3} \mathrm{~N}$

3. $\mathrm{AcCl}$

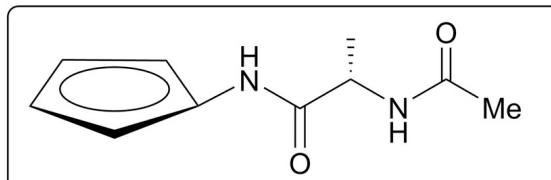

$\mathrm{Fe}$

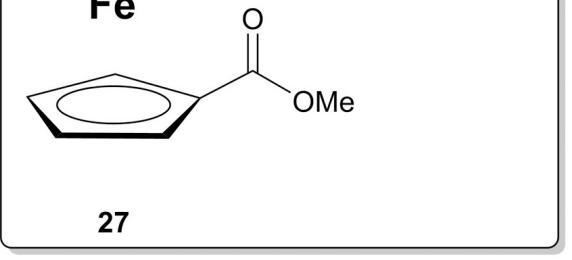<smiles>CC(=O)NC(C)C(=O)Nc1ccccc1</smiles>

$\mathrm{Fe}$

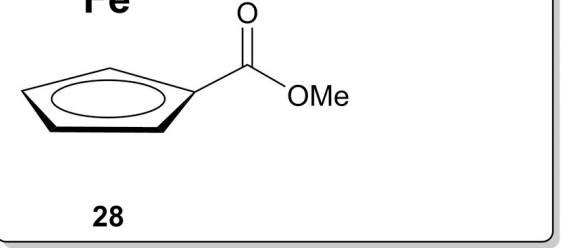

Scheme 5. Synthesis of bioconjugates 25-28.

supported the intramolecular hydrogen bonding behavior. Furthermore, an increased temperature dependencies of concentration-independent $\mathrm{NH}_{\mathrm{Fn}}[\mathbf{2 5}(-5.6 \mathrm{ppb} / \mathrm{K}), \mathbf{2 6}(-6.0$ $\mathrm{ppb} / \mathrm{K}), \mathbf{2 7}(-9.6 \mathrm{ppb} / \mathrm{K}), \mathbf{2 8}(-9.6 \mathrm{ppb} / \mathrm{K})]$ and $\mathrm{NH}_{\text {Ala }}[\mathbf{2 7}(-6.4$ $\mathrm{ppb} / \mathrm{K}), 28(-7.2 \mathrm{ppb} / \mathrm{K})]$ reflected initially shielded states transferred to unshielded environment by unfolding of conformations organized through IHBs.
Evaluation of hydrogen bond strength was carried out by DMSO titration. Rapid rise in the slope of the titration curves in the region below $20 \%$ DMSO was caused by significant changes in chemical shifts $(\Delta \delta>1 \mathrm{ppm}$ ) over the range of the ${ }^{1} \mathrm{H}$ NMR experiment, owing to participation of $\mathrm{NH}$ groups in weak IHBs (Figure 15c).

The position of hydrogen bond donating and 
accepting groups in peptides $\mathbf{2 5 - 2 8}$ allowed the formation of both inter- and intrastrand IHBs. The interstrand contacts between $\mathrm{C}$ - and $\mathrm{N}$-termini required for turn formation ${ }^{[76]}$ were observed in NOESY spectra of the examined compounds $\left[t \mathrm{Bu}_{\mathrm{Boc}} \rightarrow \mathrm{Me}_{\text {соome }} \quad(25 / 26)\right.$ and $\left.\mathrm{Me}_{\mathrm{Ac}} \rightarrow \mathrm{Me}_{\mathrm{COOMe}} \quad(27 / 28)\right]$ and might account for $\mathrm{NH}_{\text {Ala }} \cdots \mathrm{OC}_{\text {coome }} \mathrm{IHB}$. Regarding the intrastrand IHBs, the NOE contacts $\mathrm{NH}_{\mathrm{Fn}} \rightarrow \mathrm{Me}_{\mathrm{Ac}}$ in spectra of Ac-peptides 27 and

25

(a)

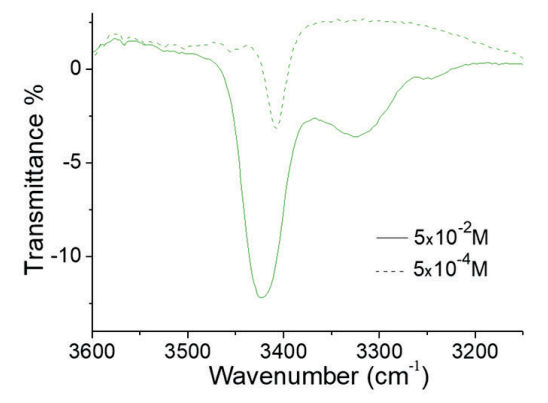

(b)

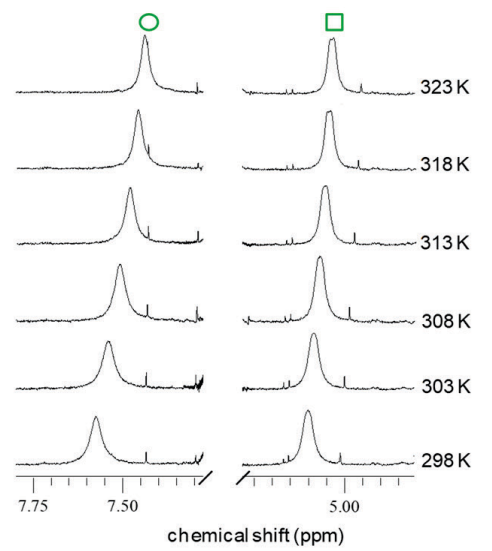

(c) $\delta(\mathrm{ppm})$

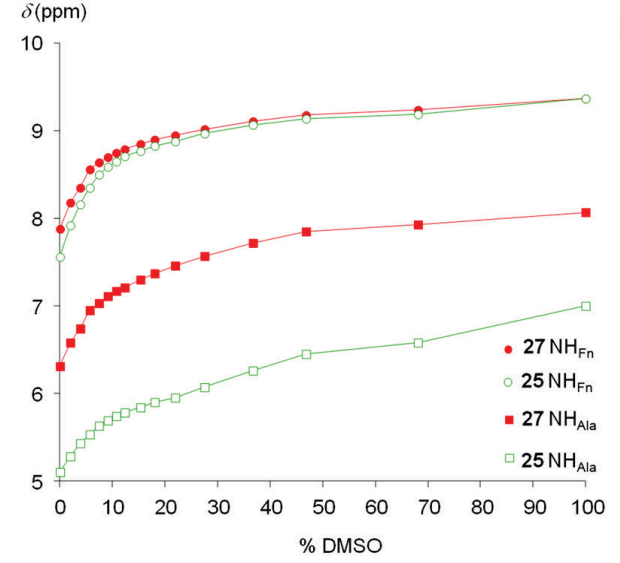

28 were detected, while the contacts of $\mathrm{NH}_{\mathrm{Fn}}$ and protons of tert-butyl group in $\mathbf{2 5}$ and $\mathbf{2 6}$ were not observed, due to the absence of hydrogen bonding along the corresponding strand. Besides that, the larger frequency of NOE contacts for $\mathrm{NH}_{\mathrm{Fn}}$ in Ac-peptides $\mathbf{2 7}$ and $\mathbf{2 8}$ in comparison to those of $\mathrm{NH}_{\mathrm{Fn}}$ in Boc-peptides $\mathbf{2 5}$ and $\mathbf{2 6}$ additionally supported the assumption of steric hindrance imposed by tert-butyl group (Figure 16).
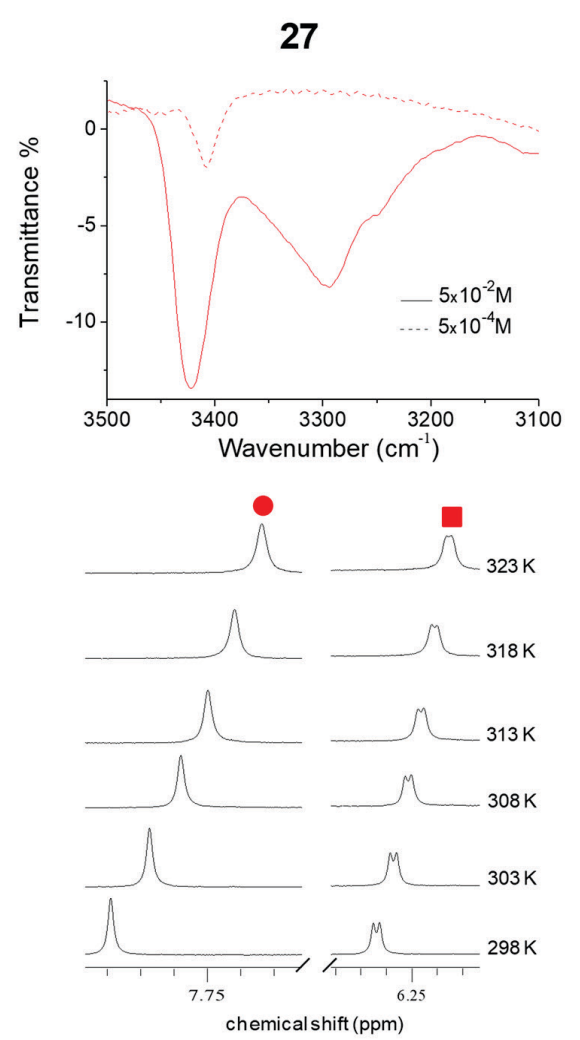

(d)

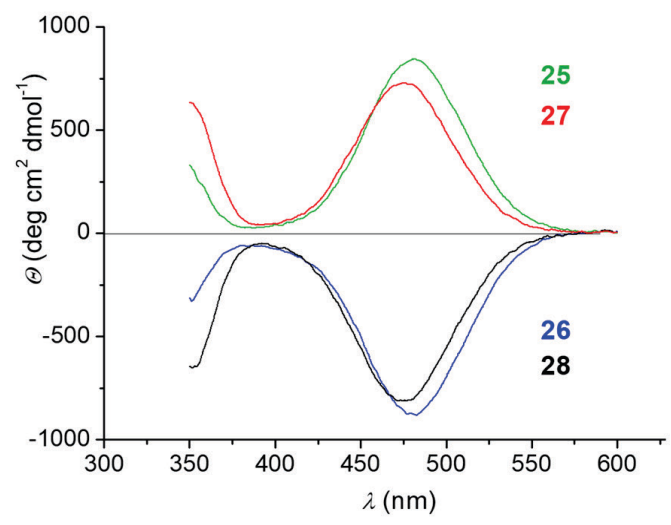

Figure 15. (a) The NH stretching vibrations in concentration-dependent IR spectra of 25 and 27 in $\mathrm{CH}_{2} \mathrm{Cl}_{2}$, (b) Temperature dependence of $\mathrm{NH}$ chemical shifts $\left(c=2.5 \times 10^{-2} \mathrm{M}\right)$ in the temperature range of 298-328 K, (c) Solvent dependence of $\mathrm{NH}$ chemical shifts at varying concentrations of $d_{6}$-DMSO in $\mathrm{CDCl}_{3}\left(c=2.5 \times 10^{-2} \mathrm{M}, 298 \mathrm{~K}\right)$ to probe exposed vs. hydrogen-bonded amides, (d) Cotton effects in chirality-organized ferrocene peptides $25-28$ in $\mathrm{CH}_{2} \mathrm{Cl}_{2}\left(c=1 \times 10^{-3} \mathrm{M}\right)$. The compatible results on IR and temperature-dependent NMR measurements were obtained for enantiomeric pairs 26 and 28. 
(a)

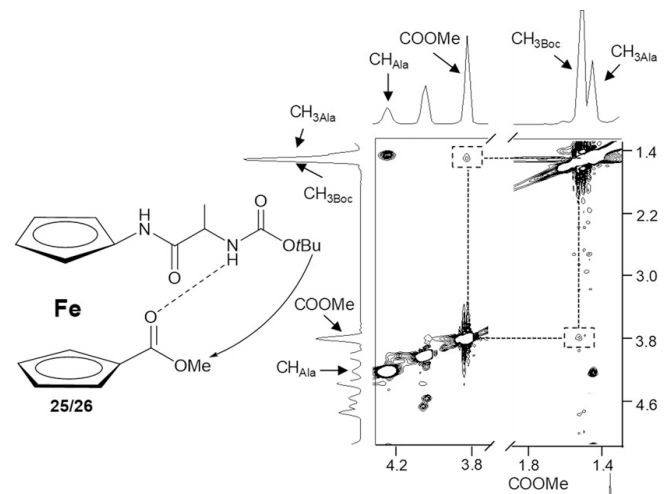

(b)

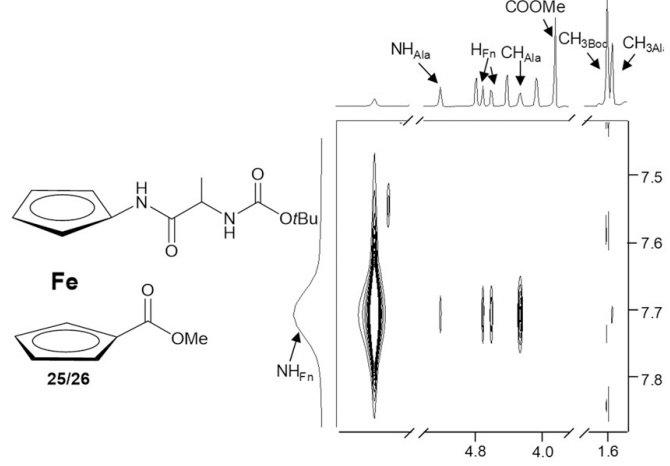

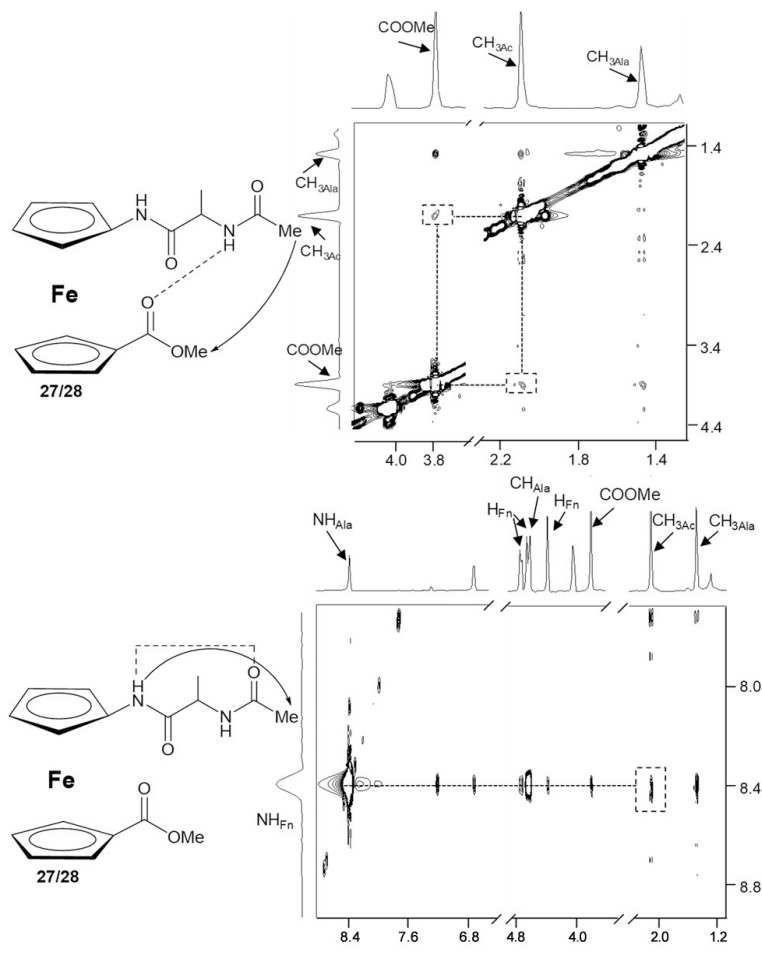

Figure 16. (a) The interchain NOE connectivities between $\mathrm{C}$ - and $\mathrm{N}$-termini of 25-28 and (b) intrachain NOE contacts for $\mathrm{NH}_{\mathrm{Fn}}$ in Boc-peptides 25/26 and Ac-peptides 27/28 (the proposed IHBs are depicted with dashed lines).

These assumptions about IHB patterning were confirmed with $C D$ signals in the region of ferrocene chromophore (Figure 15d). Mirror image arrangement of the CD curves of $\mathbf{2 5}$ and $\mathbf{2 6}$ as well as $\mathbf{2 7}$ and $\mathbf{2 8}$ resulted from their conformational enantiomeric relationship. Due to our previous findings, ${ }^{[33]}$ the positive Cotton effects of $(R)-\mathbf{2 5}$ and $(R)-\mathbf{2 7}$ were attributed to the helices of $(P)$ orientation, while corresponding enantiomers $(S)-\mathbf{2 6}$ and (S)-28 adopted an opposite (M)-oriented helices.

In our research on ferrocene-containing peptides, an experimental data were usually augmented with molecular modeling studies to obtain a detailed picture regarding hydrogen bonding. The complete conformational analysis of Boc-peptide $\mathbf{2 5}$ and Ac-peptide $\mathbf{2 7}$ was performed using combination of molecular mechanics and DFT calculations. Relative distribution of conformers for peptides $25 / 27$ with L-Ala moieties was the same for their enantiomers $26 / 28$ with D-Ala. The pseudo-torsion angle defining helicity was opposite in pair of enantiomers (for example, one enantiomer has $(P)-1,2^{\prime}$ and the other $(M)-1,5^{\prime}$ configuration), while the hydrogen bonding pattern was the same, as the molecular geometry of one enantiomer is only the mirror image of the other.

The DFT analysis results that predicted three IHB motifs $\mathbf{A}-\mathbf{C}$ were compatible with NMR data (Figure 17). The most stable conformers of $\mathbf{2 5}$ and $\mathbf{2 7}$ were found to adopt
$\mathrm{NH}_{\mathrm{Fn}} \cdots \mathrm{OC}_{\mathrm{Boc} / \mathrm{Ac}}$ intrastrand $\mathrm{IHB}$ forming 7-membered ring [( $\gamma$-turn), (type $A)]$ or $\mathrm{NH}_{\mathrm{Fn}} \cdots \mathrm{N}_{\text {Ala }}$ intrastrand IHB forming 5membered ring of the type $\mathbf{B}$. In the ensemble of the most stable conformers, single interstrand $\mathrm{NH}_{\mathrm{Ala}} \cdots \mathrm{OC}_{\mathrm{Fn}} \mathrm{IHB}$ of the type $\mathbf{C}$ was observed only in Ac-peptide 27. The same observations were valid for their enantiomers $\mathbf{2 6}$ and $\mathbf{2 8}$.

\section{Bioconjugates of 1-Acetyl-1'- aminoferrocene with Amino Acids (33-35, 39-41) and Their Monosubstituted Analogues (30-32, 36-38)}

Bioconjugates 33-35 (Boc-AA-NH-Fn-COMe; AA = Gly, LAla, L-Val) ${ }^{[77]}$ and 39-41 [Boc-(AA) ${ }_{2}-\mathrm{NH}-\mathrm{Fn}-\mathrm{COMe} ; \mathrm{AA}=\mathrm{Gly}$, L-Ala, L-Val] ${ }^{[78]}$, derived by $\mathrm{N}$-terminal elongation of Boc-NH$\mathrm{Fn}-\mathrm{COMe}$, can also be considered as nonsymmetric analogues of ferrocene-containing peptidomimetics IV (Scheme 6). These derivatives were subjected to detailed CD, IR and NMR spectroscopic analysis, combined with theoretical investigation (DFT), to describe their preferred conformations in solution. Furthermore, to gain better insight on the hydrogen bond patterns in 33-35 and 39-41, a complete set of their monosubstituted analogues 30-32 (Boc-AA-NH-Fn; AA = Gly, L-Ala, L-Val) and 36-38 [Boc$(\mathrm{AA})_{2}-\mathrm{NH}-\mathrm{Fn} ; \mathrm{AA}=\mathrm{Gly}$, L-Ala, L-Val] was synthesised and subjected to conformational analysis as well. 
<smiles>[X]C(=O)NC(C)C(=O)Nc1ccccc1</smiles>

$\mathrm{Fe}$

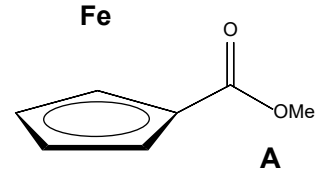

A<smiles>[X]C(=O)NC(C)C(=O)Nc1ccccc1</smiles>

$\mathrm{Fe}$

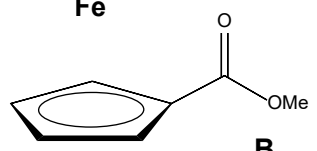

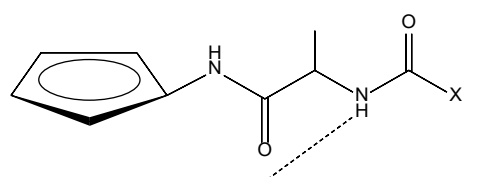

$\mathrm{Fe}$

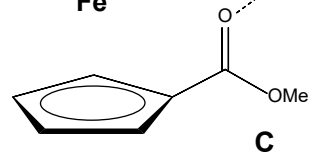

C

Figure 17. The intramolecular hydrogen bonding patterns observed in the ensemble of the most stable conformers based on computational study for $25(X=\mathrm{OtBu})$ and $27(\mathrm{X}=\mathrm{Me})$.<smiles>CCCCOC(=O)Nc1ccccc1</smiles>

$\mathrm{Fe}$

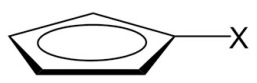

1. HClgaseous

2. $\mathrm{Et}_{3} \mathrm{~N}$

3. BOC-AA-OH/ EDC, HOBt

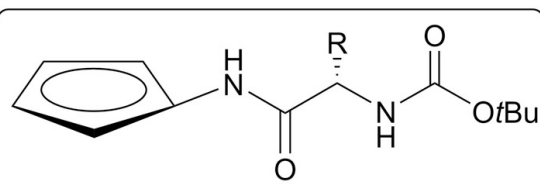

Fe

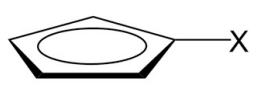

$30, X=H, R=H$

31, $X=\mathrm{H}, \mathrm{R}=\mathrm{CH}_{3}$

32, $\mathrm{X}=\mathrm{H}, \mathrm{R}=\mathrm{CH}\left(\mathrm{CH}_{3}\right)_{2}$

33, $\mathrm{X}=\mathrm{COCH}_{3}, \mathrm{R}=\mathrm{H}$

34, $\mathrm{X}=\mathrm{COCH}_{3}, \mathrm{R}=\mathrm{CH}_{3}$

35, $\mathrm{X}=\mathrm{COCH}_{3}, \mathrm{R}=\mathrm{CH}\left(\mathrm{CH}_{3}\right)_{2}$

29

1. HClgaseous

2. $\mathrm{Et}_{3} \mathrm{~N}$

3. BOC-AA-OH/ $\mathrm{EDC}, \mathrm{HOBt}$<smiles>[R]C(NC(=O)OCCC)C(=O)NC([R])C(=O)Nc1ccccc1</smiles>

Fe

$$
\begin{aligned}
& \text { X } X, X=H, R=H \\
& 37, X=H, R=\mathrm{CH}_{3} \\
& 38, X=H, R=C H\left(\mathrm{CH}_{3}\right)_{2} \\
& 39, X=\mathrm{COCH}_{3}, \mathrm{R}=\mathrm{H} \\
& 40, \mathrm{X}=\mathrm{COCH}_{3}, \mathrm{R}=\mathrm{CH}_{3} \\
& 41, \mathrm{X}=\mathrm{COCH}_{3}, \mathrm{R}=\mathrm{CH}\left(\mathrm{CH}_{3}\right)_{2}
\end{aligned}
$$

Scheme 6. Synthesis of bioconjugates 30-41

The downfield resonance of $\mathrm{NH}_{\mathrm{Fn}}(\sim 7.7 \mathrm{ppm})$, observed in the NMR spectra of 30-35, indicated its participation in a hydrogen bond. Although the $\mathrm{NH}_{\mathrm{AA}}$ resonances were registered at high field (5.1-5.5 ppm), we did not exclude the possibility of involvement of these groups in hydrogen bonding due to examples of urethane $\mathrm{NH}$ groups resonating at high field in $\mathrm{CDCl}_{3},[79,80]$ During NMR dilution experiments in the concentration range of
$1.5-100 \mathrm{mM}$ any significant variation of $\mathrm{NH}_{\mathrm{Fn}}$ resonances was not observed $(\Delta \delta<0.2 \mathrm{ppm})$, so we attributed the initial chemical shift to intramolecular hydrogen bonding. Furthermore, to determine the strength of bonds involving $\mathrm{NH}$ group directly attached to ferrocene, we performed DMSO titration experiments. As can be seen in Figure 18, the gradual addition of DMSO (from 0 to $30 \%$ in $\mathrm{CDCl}_{3}$ ) caused the dramatic downfield shift of $\mathrm{NH}_{\mathrm{Fn}}$ protons of $\mathbf{3 2}$ 
(a)

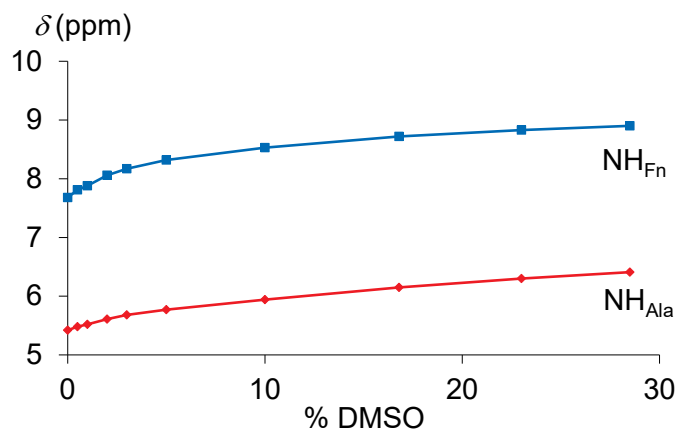

(b)

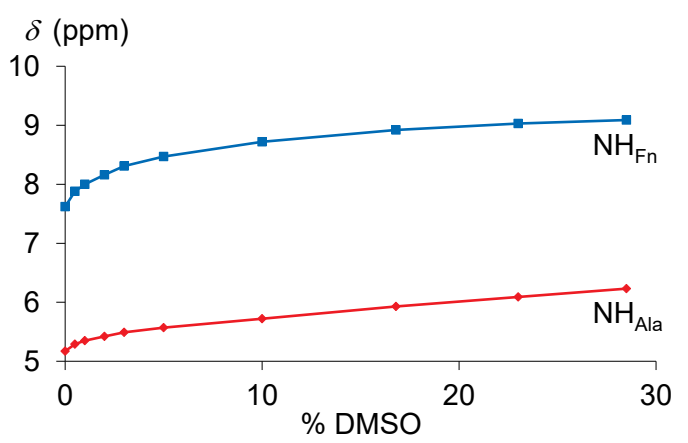

(c)

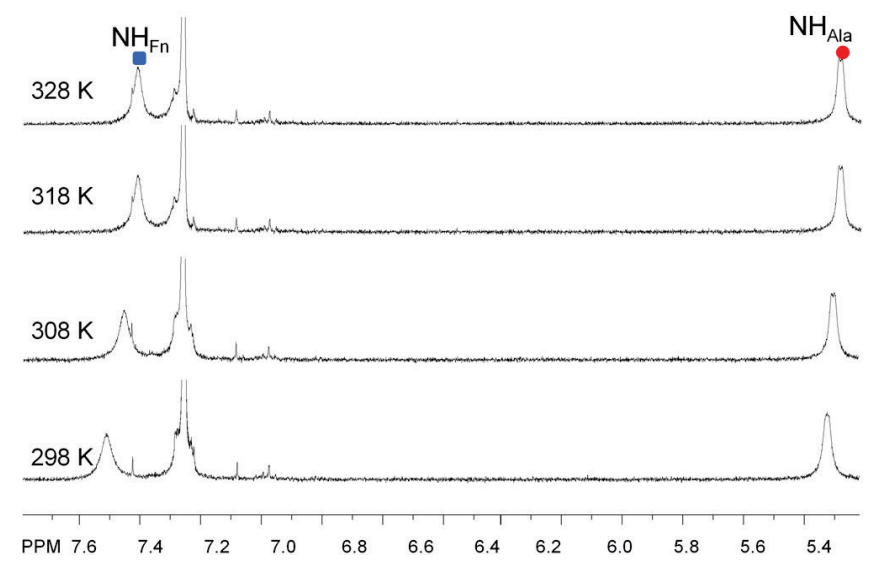

Figure 18. Solvent dependence of NH chemical shifts of compounds (a) 32 and (b) 34 at varying concentrations of $d_{6}$-DMSO in $\mathrm{CDCl}_{3}\left(c=2.5 \times 10^{-2} \mathrm{M}, 298 \mathrm{~K}\right)$ to probe exposed vs. hydrogen-bonded amides, (c) Temperature dependence of $\mathrm{NH}_{\mathrm{Fn}}$ and $\mathrm{NH}_{\text {Ala }}$ chemical shifts of compound $34\left(c=2.5 \times 10^{-2} \mathrm{M}\right)$ in the temperature range of $298-328 \mathrm{~K}$.

(1.22 ppm) and 34 (1.41 ppm), suggesting that these bonds are easily disrupted by the presence of competitive solvent. Similar solvent accessibility was observed for $\mathrm{NH}_{\text {AA }}$ group.

Furthermore, large temperature coefficients of $\mathrm{NH}_{\text {Fn }}$ protons in disubstituted conjugates $(\Delta \delta / \Delta T=-4.67$, -4.67 , and $-6 \mathrm{ppb} \mathrm{K}^{-1}$ for 33,34 , and 35 , respectively) were indication of an initially shielded $\mathrm{NH}$ groups which become exposed with increasing of temperature (Figure 18c).

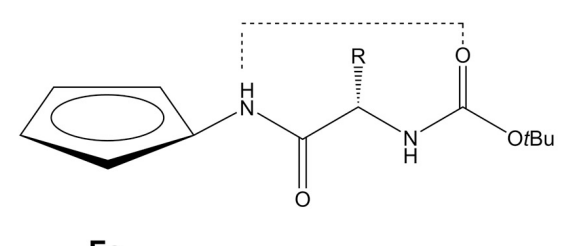

$\mathrm{Fe}$

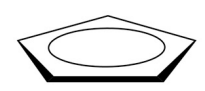

The hydrogen-bond patterns found in the most stable conformers of 30-35, derived from the computational study, are shown in Figure 19. The results of DFT study were in accordance with those derived from NMR measurements; in minimal energy conformer of all derivatives, $\mathrm{NH}$ group directly attached to the ferrocene was involved in a hydrogen bond with urethane carbonyl. Disubstituted conjugates (3335) were additionally stabilized by an interchain bond between $\mathrm{NH}_{\mathrm{AA}}$ and the acetyl carbonyl.

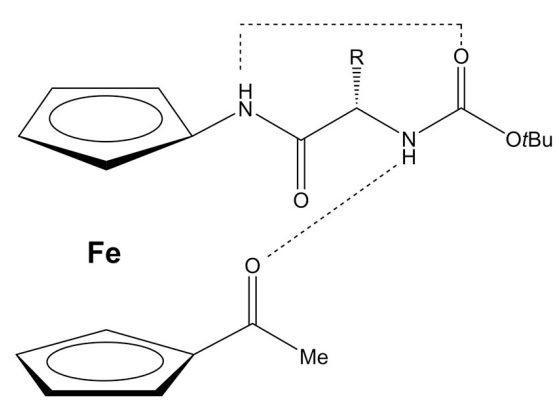

Figure 19. The intramolecular hydrogen bonding patterns observed in the most stable conformer based on computational study for mono- (30-32, left) and disubstituted conjugates (33-35, right). 

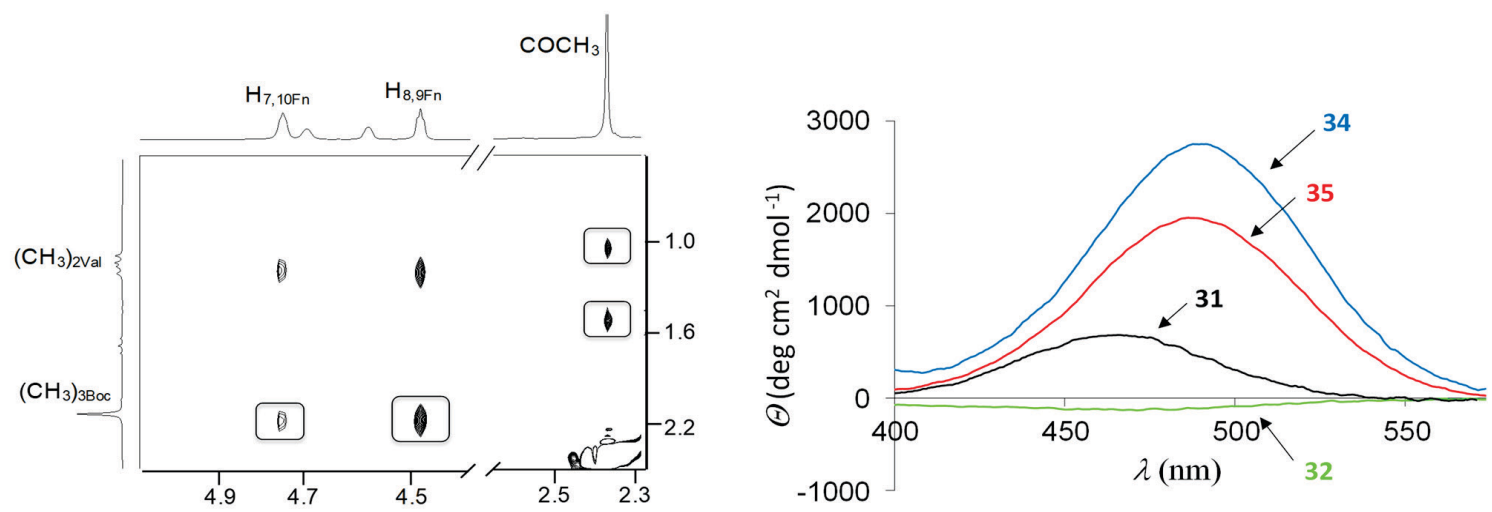

Figure 20. Important NOE interactions of $\mathbf{3 5}$ (left) and Cotton effects in chirality-organized ferrocene peptides $\mathbf{3 1}, \mathbf{3 2}, \mathbf{3 4}$ and 35 (right).

NOESY experiments and CD spectroscopy provided further evidence for interchain interactions in the disubstituted conjugates 33-35. "Superimposable" orientation of substituents on cyclopentadienyl rings rings, caused by interstrand bonding, was supported by observation of NOESY cross-peaks shown on Figure 20 for derivative 35. The visible regions of CD-spectra of chiral derivatives (31, 32, 34 and 35) are shown in the same Figure. Monosubstituted conjugates $\mathbf{3 1}$ and $\mathbf{3 2}$ exhibited a weak signal near UV/Vis absorption maximum of the ferrocene chromophore $\left(M_{\Theta}=683\right.$ and $\left.-133 \mathrm{deg} \mathrm{cm}^{2} \mathrm{dmol}^{-1}\right)$, as expected for derivatives unable to form interchain hydrogen bonds. ${ }^{[81]}$ Medium-intensity CD-signals, observed in the spectra of $\mathbf{3 4}$ and $\mathbf{3 5}\left(M_{\Theta}=2751\right.$ and $1953 \mathrm{deg} \mathrm{cm}^{2}$ $\mathrm{dmol}^{-1}$ ), indicated an ordered chiral environment in the vicinity of ferrocene moiety arised from interstrand hydrogen bonding. The sign of Cotton effect founded in CD spectra of $\mathbf{3 4}$ and $\mathbf{3 5}$ was in accordance with previously described literature examples where bioorganometallics derived from L-amino acids exhibited positive CD signals, induced by $P$-helicity of energetically accessible conformers ${ }^{[33 b, 74,75]}$

Peptides 36-41 were synthesised by $\mathrm{N}$-terminal elongation of their lower homologues 30-35 and subjected to conformational analysis using IR and NMR spectroscopic techniques in combination with DFT calculations. In the solution IR spectra of all compounds signals belonging to hydrogen-bonded $\mathrm{NH}$ groups together with signals above $3440 \mathrm{~cm}^{-1}$ due to presence of free $\mathrm{NH}$ groups were observed. We ruled out the possibility of intermolecular hydrogen bonding by performing IR-dilution experiment, over a concentration range of 50 to $0.5 \mathrm{mM}$ (Figure 21a). Next, we undertook NMR study to find out which $\mathrm{NH}$ groups participate in hydrogen bonds as suggested by IRspectroscopy. Involvement of $\mathrm{NH}$ attached to the ferrocene moiety in a hydrogen bond was indicated by its downfield shifted signal ( 8.1 ppm) in spectra of all conjugates. In contrast, signals of $\mathrm{NH}_{\text {AA1 } 1}$ as well as the $\mathrm{NH}_{\mathrm{AA} 2}$ were registered at $\sim 6.8$ and $\sim 5.2 \mathrm{ppm}$, indicating that former $\mathrm{NH}$ group equilibrates between bonded and non-bonded states and later does not participate in hydrogen bonds. Furthermore, in all conjugates $\mathrm{NH}_{\mathrm{Fn}}$ and $\mathrm{NH}_{\mathrm{AA} 1}$ were significantly less accessible to the solvent than $\mathrm{NH}_{\mathrm{AA} 2}$ as can be seen from DMSO titration experiments, shown on Figure 21b.

In order to determine the dominant conformations of 36-41 in solution, search of the conformational space at the B3LYP/6-311 $(+G(d, p)$ and LanL2DZ for iron) level of theory was performed. According to computational analysis, the lowest energy conformer of monosubstituted derivatives $\mathbf{3 6 - 3 8}$ was stabilized by $\beta$-turn-like structure $i$. e., 10-membered hydrogen-bonded ring formed between the $\mathrm{NH}$ group closest to the ferrocene unit and the urethane carbonyl group (Figure 22). This finding was in agreement with the results obtained from NOE experiments. As can be seen in Figure 22, sequential dNN $(i, i+1)$ and $\mathrm{d} \alpha \mathrm{N}(i, i+1)$ connectivities, characteristic for $\beta$-turn, were observed in the NOESY spectra of conjugates 36-38.

Furthermore, an ordered environment in the vicinity of ferrocene chromophore gave rise to a strong signal in CD spectra of chiral derivatives $\mathbf{3 7}$ and $\mathbf{3 8}$ (Figure 23). These results were in contrast with previous examples in which strong Cotton effects originate from helically chiral arrangements of the ferrocene moiety supported by interchain hydrogen bonds between the two podand peptide chains. ${ }^{[33 b]}$ So, for the first time we demonstrated that a transfer of chiral information from a folded peptide chain to ferrocene chromophore can also give rise to a strong signals around the UV/Vis absorption maximum of the ferrocene chromophore $\left(\lambda_{\max } \approx 455 \mathrm{~nm}\right.$ ).

In the analogous 1-acetyl derivatives (39-41), $\beta$-turnlike structures were destabilized according to computational study, NOESY and CD experiments. This findings can be explained by the fact that heteroannular introduction of 
37

(a)

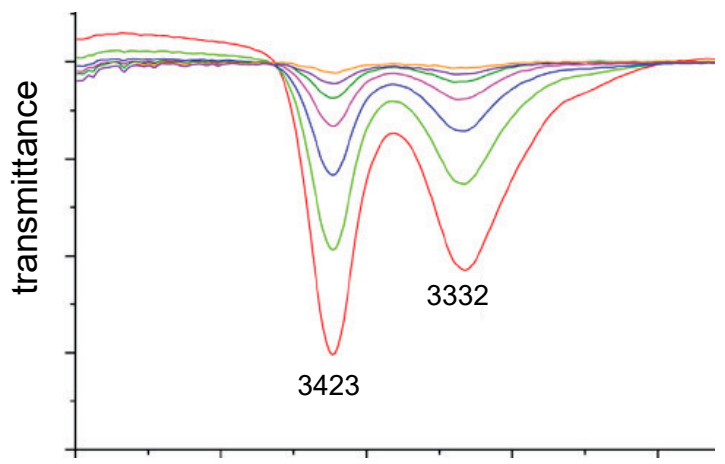

wavenumber $\left(\mathrm{cm}^{-1}\right)$

(b)

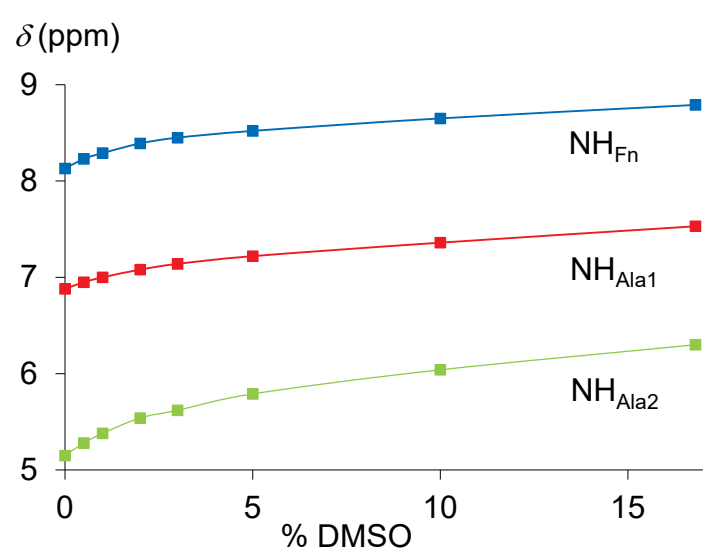

40

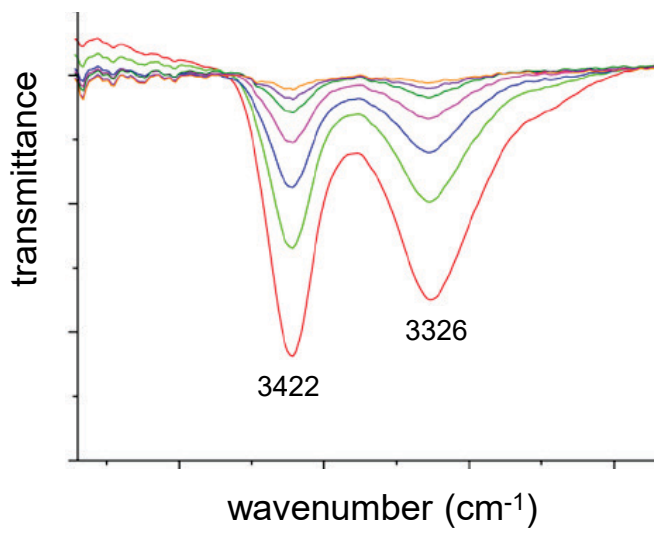

$\delta(\mathrm{ppm})$

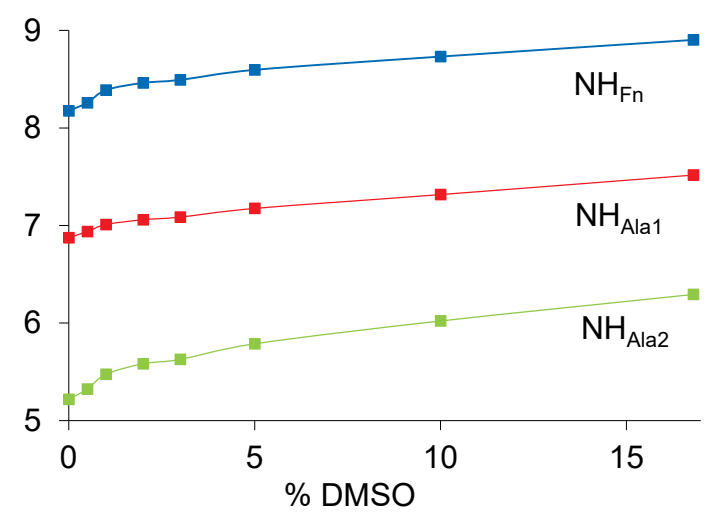

Figure 21. (a) The $\mathrm{NH}$ stretching vibrations in concentration-dependent IR spectra of 37 and 40 in $\mathrm{CH}_{2} \mathrm{Cl}_{2}\left(c=5 \times 10^{-2} \mathrm{M}\right)$, (b) Solvent dependence of $\mathrm{NH}$ chemical shifts of compounds 37 and 40 at varying concentrations of $d_{6}-\mathrm{DMSO}$ in $\mathrm{CDCl}_{3}(c=$ $\left.2.5 \times 10^{-2} \mathrm{M}, 298 \mathrm{~K}\right)$ to probe exposed vs. hydrogen-bonded amides.

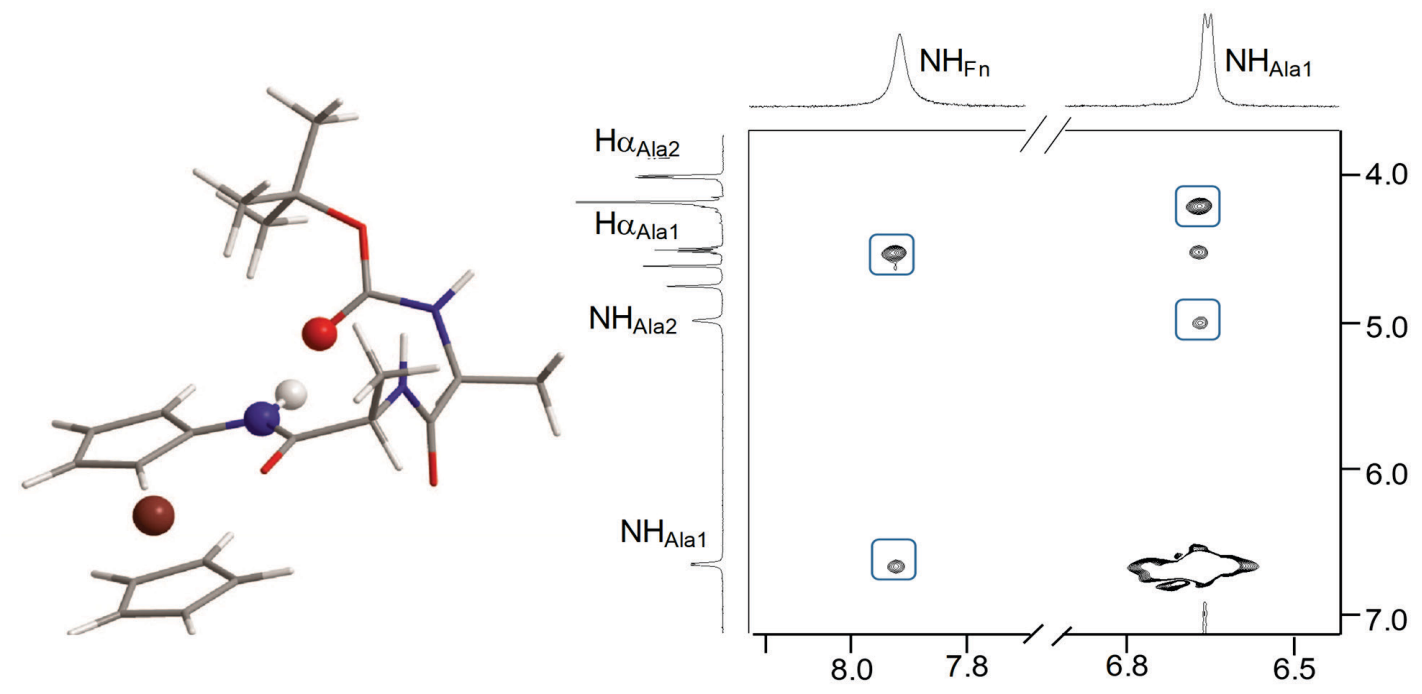

Figure 22. The most stable conformer and important interactions in NOESY spectrum of 37. 


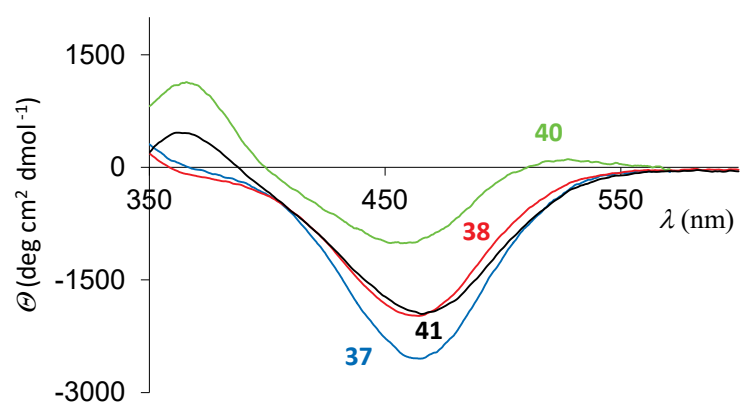

Figure 23. Cotton effects in chirality-organized ferrocene peptides 37, 38, 40 and 41 in $\mathrm{CH}_{2} \mathrm{Cl}_{2}\left(c=1 \times 10^{-3} \mathrm{M}\right)$.

an additional hydrogen bond acceptor group (COMe) enabled the conjugates 39-41 to form interchain hydrogen bonds and to expand their accessible conformational space. The hydrogen bond patterns found in the ensemble of the most stable conformers based on computational study of derivatives 39-41 are shown in Figure 24.

\section{Bioconjugates of Aminoferrocene with Homo- and Heterochiral Pro-Ala Sequences (42-45)}

Encouraged by the results of conformational analysis and interesting chirooptical properties of 36-38 described above, we have synthesized four homo- and heterochiral aminoferrocene derived peptides: Boc $-\mathrm{AA}_{2}-\mathrm{AA}_{1}-\mathrm{NH}-\mathrm{Fn}$ (42, $\mathrm{AA}_{1}=\mathrm{L}$-Ala, $\mathrm{AA}_{2}=\mathrm{L}$-Pro; 43, $\mathrm{AA}_{1}=\mathrm{D}-\mathrm{Ala}, \mathrm{AA}_{2}=\mathrm{D}$-Pro; 44, $\mathrm{AA}_{1}=\mathrm{L}-\mathrm{Ala}, \mathrm{AA}_{2}=\mathrm{D}-\mathrm{Pro} ; \mathbf{4 5}, \mathrm{AA}_{1}=\mathrm{D}-\mathrm{Ala}, \mathrm{AA}_{2}=\mathrm{L}-$ Pro). ${ }^{[82]}$ The prefered conformation, according to thorough experimental and theoretical analysis, of homochiral derivatives $\mathbf{4 2}$ and $\mathbf{4 3}$ in solution was $\beta$-turn-like structure (Figure 25b). As can be seen in Figure 25a, chiral information was transferred from this local secondary structure to a ferrocene chromophore giving rise to strong mirror-image signals in the visible region of the CD spectra of enantiomeric $\mathbf{4 2}$ and $\mathbf{4 3}$.

The change of the chirality of the amino acid at the $i+1$ position (Pro) caused a disruption of $\beta$-turn-like secondary structure in the derived heterochiral peptides 44 and 45 , as suggested by the CD and NMR spectroscopy analysis. Computational study proposed that lowest energy conformers of heterochiral derivatives were stabilized by two consecutive $\gamma$-turns in solution of aprotic solvents (Figure 25b).

On the contrary, the single-crystal $\mathrm{X}$-ray structures of heterochiral Boc-D-Pro-L-Ala-NH-Fn (44) and Boc-L-ProD-Ala-NH-Fn (45) were characterized by the presence of 10-membered hydrogen-bond ring between $\mathrm{NH}$ adjacent to the ferrocene moiety and urethane carbonyl group (Figure 26). Intramolecular hydrogen bonding supported the formation of $\beta$-turn structure similar to an ideal type II $\beta$-turn. The right-handed sense of helical induction was observed in the structure of $\mathbf{4 5}$ while enantiomeric $\mathbf{4 4}$ favoured left-handed helical conformation.

Having in mind the results that clearly showed that the transfer of the chiral information from folded peptide chain to organometallic chromophore gives rise to strong response in the ferrocene region of $C D$ spectra, our current research is focused on synthesis, conformational analysis and chirooptical properties of bioconjugates with a potential to form minimum sized peptide helices.
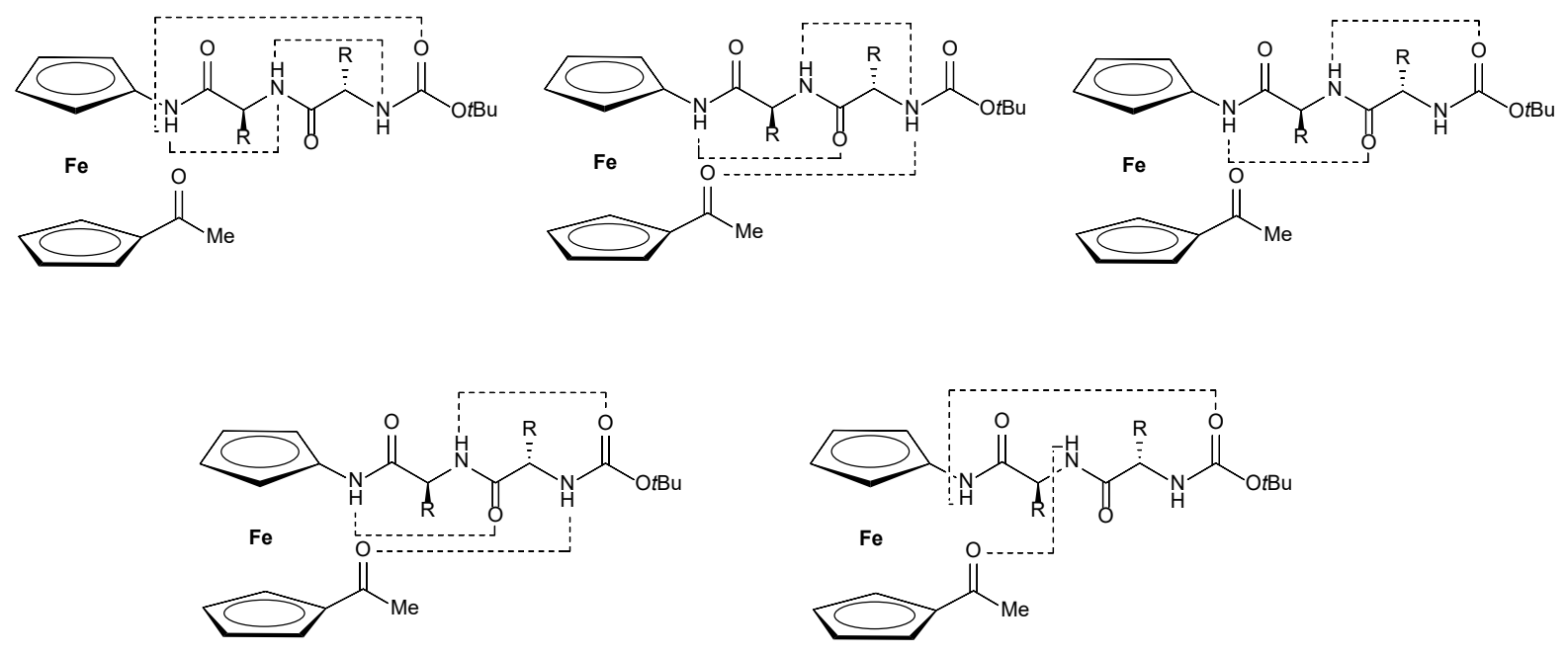

Figure 24. IHB patterns observed in the ensemble of the most stable conformers based on computational study for disubstituted conjugates 39-41. 


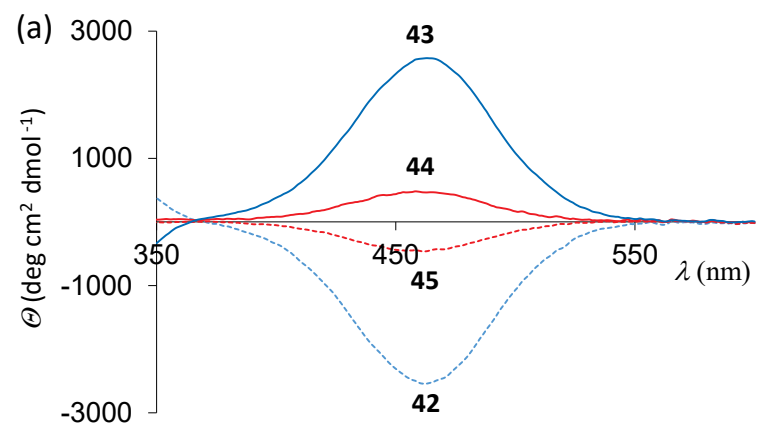

(b)

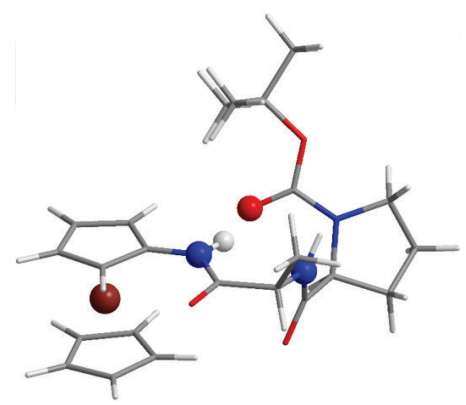

Boc-L-Pro-L-Ala-NH-Fn (42)

(c)

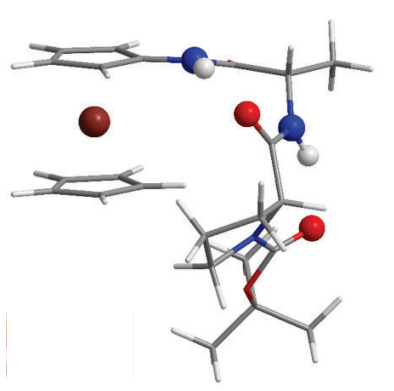

Boc-L-Pro-D-Ala-NH-Fn (45)

Figure 25. (a) Cotton effects in chirality-organized ferrocene peptides 42-45 in $\mathrm{CH}_{2} \mathrm{Cl}_{2}\left(\mathrm{c}=1 \times 10^{-3} \mathrm{M}\right)$, (b) $\beta$-turn structure in the most stable conformer of homochiral peptide $\mathbf{4 2}$ and (c) $\gamma$-turns in the hetorochiral derivative $\mathbf{4 5}$.

\section{Biconjugates of Ferrocene-1,1'-diamine and Alanine (48 and 49)}

Unlike peptides III and IV that have been widely reported, only one paper dealing with two symmetrically disubstituted homochiral peptides $\mathrm{Fn}-(\mathrm{NH}-\mathrm{AA}-\mathrm{Boc})_{2}$ (Va, $A A=L$ or $D-A l a)$, derived from $\mathrm{Fn}(\mathrm{NHBoc})_{2}$, was given by Kraatz et al. ${ }^{\left[{ }^{[4]}\right]}$ They have demonstrated that 14-membered ring between attached symmetrical peptide chains, very similar to those founded in antiparallel $\beta$-sheet peptides, was formed. Therefore, ferrocene-1,1'-diamine (Fcda) scaffold was established as a desired structural requirement for turn induction and mimicking the natural structure of antiparallel $\beta$-sheet. Within our recent research, ${ }^{[83]}$ we have designed a synthetic approach to unsymmetrically disubstituted and orthogonally protected conjugates Ac-Ala-NH-Fn-NH-Ala-Boc (48) and Fn-(NHAla-Ac) 2 (49) (peptides of type $V$ ), with aim to explore whether the replacement of one or both Boc groups of Va with sterically less demanding Ac groups in $\mathbf{4 8}$ and $\mathbf{4 9}$ will affect the IHB pattern realized through 14-membered $\mathrm{NH}_{\mathrm{Fn}} \cdots \mathrm{OC}_{\mathrm{BoC}} \mathrm{IHB}$ ring.

The key intermediate 47, containing $\mathrm{NH}$ groups attached to both $\mathrm{Cp}$ rings, was obtained from $\mathrm{Ac}-\mathrm{Ala}-\mathrm{NH}-$ Fn-COOMe (27). ${ }^{[74]}$ The product obtained upon saponification of its ester group was transferred to orthogonally protected compound $\mathbf{4 7}$ via unstable azide $\mathbf{4 6}$. Then, acidic Boc-deprotection of $\mathbf{4 7}$ and coupling with activated Boc-Ala-OH gave orthogonally protected AcAla-NH-Fn-NH-Ala-Boc (48). Upon (i) Boc-deprotection and (ii) Ac-protection in the presence of acetyl chloride, ${ }^{[84]}$ $\mathrm{Fn}-(\mathrm{NH}-\mathrm{Ala}-\mathrm{Ac})_{2}(49)$ was obtained (Scheme 7).

The both goal compounds displayed the similar IR behavior, based on dominant intramolecular hydrogen bonding engagement. Since the ratios of hydrogen-bonded and non-bonded $\mathrm{NH}$ peak intensities in their IR spectra were almost the same, the steric hindrance of Boc group was excluded.

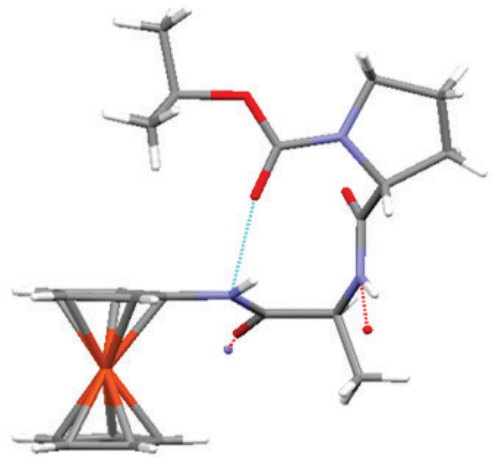

Boc-D-Pro-L-Ala-NH-Fn (44)

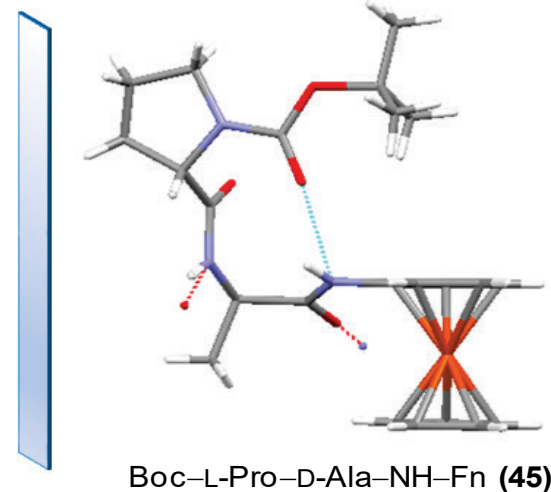

Boc-L-Pro-D-Ala-NH-Fn (45)

Figure 26. The enantiomeric $\beta$-turns in the crystal structures of heterochiral peptides $\mathbf{4 4}$ and $\mathbf{4 5}$. 
<smiles>CC(=O)NC(C)C(=O)Nc1ccccc1</smiles>

$\mathrm{Fe}$<smiles>COC(=O)c1ccccc1</smiles>

27<smiles>CC(=O)N[C@@H](C)C(=O)Nc1ccccc1</smiles>

Fe<smiles>CCCCOC(=O)Nc1ccccc1</smiles>

47

1. $\mathrm{HCl}_{\text {gas }}$

2. $\mathrm{Et}_{3} \mathrm{~N}$

3. Boc-Ala-OH/EDC, HOBt
$\stackrel{\mathrm{NaOH} / \mathrm{H}_{2} \mathrm{O}}{\longrightarrow}$

$\mathrm{MeOH}$<smiles>CC(=O)N[C@@H](C)C(=O)Nc1ccccc1</smiles>

$\mathrm{Fe}$<smiles>O=C(O)c1ccccc1</smiles>

$27 a$
$t-\mathrm{BuOH}$

$\triangle$<smiles>CC(=O)N[C@@H](C)C(=O)Nc1ccccc1</smiles>

$\mathrm{Fe}$<smiles>NC(=O)c1ccccc1</smiles>

46
1. $\mathrm{HCl}_{\text {gas }}$

2. $\mathrm{Et}_{3} \mathrm{~N}$

3. $\mathrm{AcCl}$
$\mathrm{Fe}$<smiles>CCCCOC(=O)NC(C)C(N)=O</smiles>

48

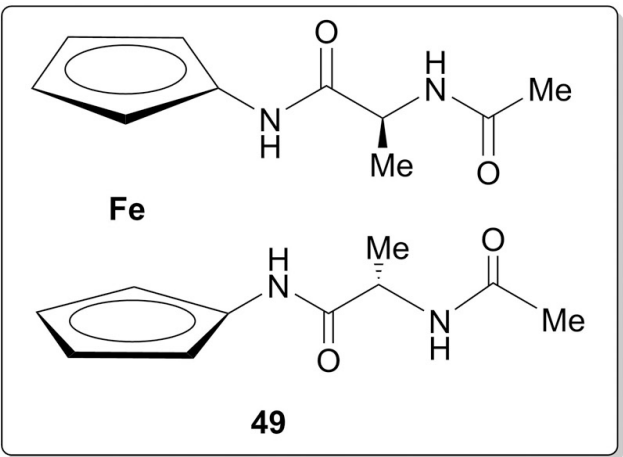

Scheme 7. The synthesis of bioconjugates 48 and 49 .

The concentration-independent NMR data suggested the participation of downfield shifted $\mathrm{NH}_{\mathrm{Fn}}$ of $\mathbf{4 8}$ and 49 in intramolecular $\mathrm{HB}$, while $\mathrm{NH}_{\mathrm{Ac}}$ protons experienced upfield shifting upon dilution, probably due to their involvement to a lesser extent in intermolecular HB. Therefore, the larger temperature dependencies of $\mathrm{NH}_{\mathrm{Fn}}$ and $\mathrm{NH}_{\mathrm{Ac}}$ were attributed to unfolding or dissociation of the initially shielded states, while the low temperature dependence of upfield shifted NHBoc corroborated its noninvolvement in HB (Figure 27a). The titration with hydrogen-bond-accepting DMSO did not affect the chemical shifts of $\mathrm{NH}_{\mathrm{Fn}}$ protons, suggesting their involvement in a strong IHBs. The pronounced changes in chemical shifts were observed for $\mathrm{NH}_{\mathrm{Ac}}$ and $\mathrm{NH}_{\mathrm{Boc}}(\Delta \delta>1.7 \mathrm{ppm})$, confirming the proposed non-hydrogen-bonded state for $\mathrm{NH}_{\mathrm{BoC}}$ as well as involvement of $\mathrm{NH}_{\mathrm{Ac}}$ in a weak $\mathrm{HB}$ (Figure 27b). 
(a)
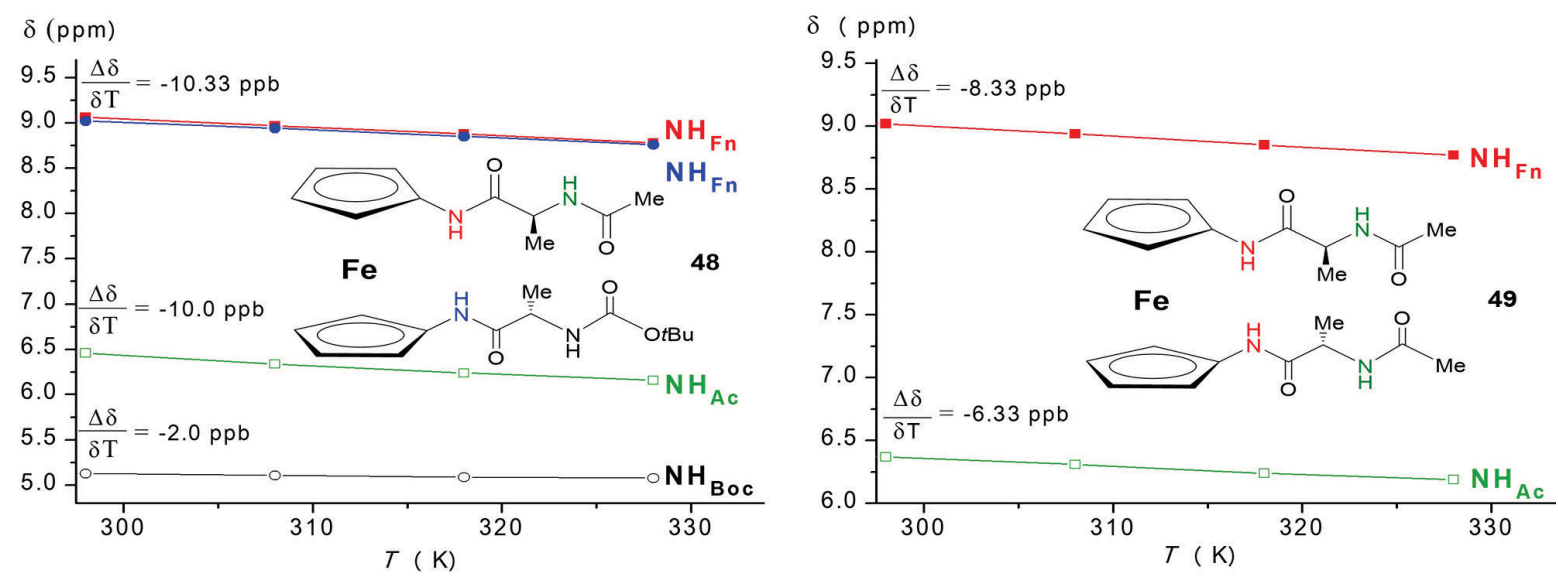

(b)
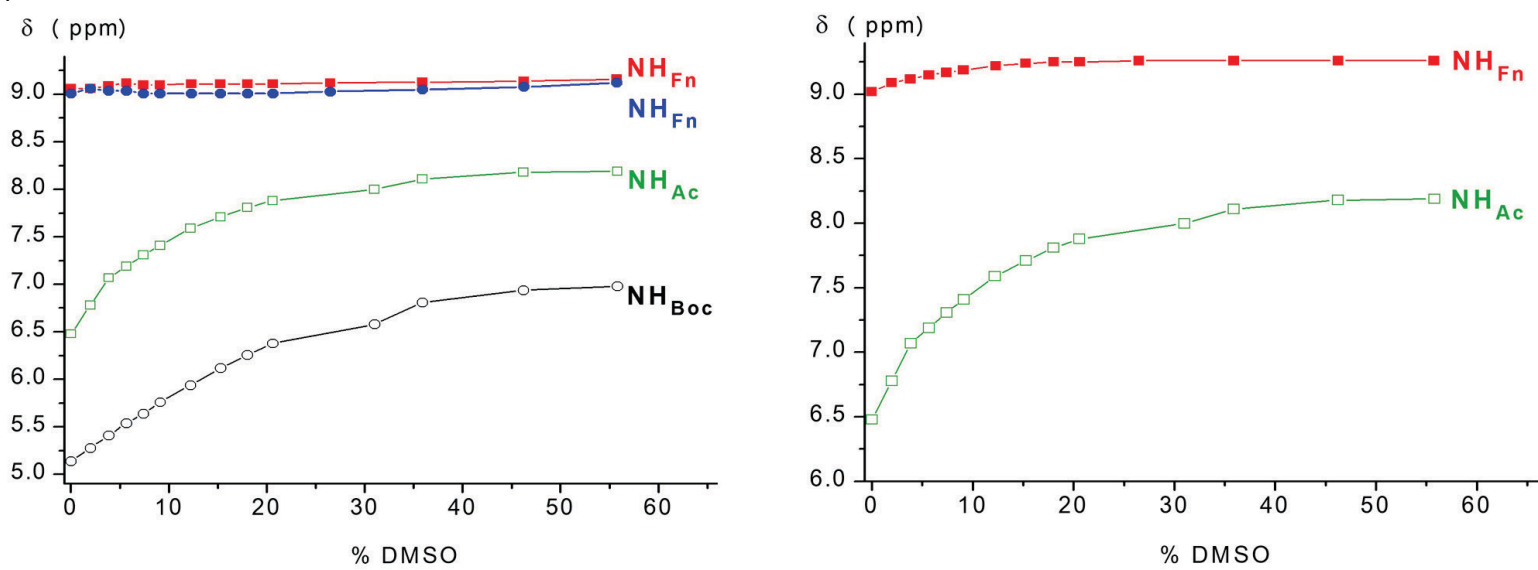

Figure 27. (a) Temperature dependence of $\mathrm{NH}$ chemical shifts of peptides 48 and $49\left(\mathrm{c}=2.5 \times 10^{-2} \mathrm{M}\right)$ in the temperature range of 298-328 K, (b) Solvent dependence of NH chemical shifts of 48 and 49 at varying concentrations of $d_{6}-\mathrm{DMSO}_{\mathrm{in}} \mathrm{CDCl}_{3}(\mathrm{c}=$ $2.5 \times 10^{-2} \mathrm{M}, 298 \mathrm{~K}$ ) to probe exposed vs. hydrogen-bonded amides.

These results contributed to define the conformational environment based on $\mathrm{NH}_{F n} \cdots \mathrm{OC}_{\mathrm{Boc}} / \mathrm{AC}$ IHBs. The interstrand $\mathrm{NOE}$ contact observed between $\mathrm{NH}_{\mathrm{Fn}}$ linked at one $\mathrm{Cp}$ ring and $t \mathrm{Bu}$ group belonging to the chain attached to another $\mathrm{Cp}$ ring supported the proposed interstrand intramolecular hydrogen bonding engagement and the presence of 14-membered ring (Figure 28a).

The observed strong Cotton effects in the region of ferrocene-based transitions around $470 \mathrm{~nm}$ supported the highly organized chiral surrounding around ferrocene unit. Considering that Cotton effect reflects an average of the entire molecular population, the prevalence of $P$-helicity was strongly supported. Furthermore, the conservation of $\sim 70 \%$ of CD activity in the presence of $20 \%$ of DMSO was an additional confirmation of the involvement of the tested peptides in strong IHBs (Figure 28b).

The computational study of the bioconjugates 48 and 49 confirmed the NMR proposed hydrogen bonding patterns. Thereat, the interchain $\mathrm{NH}_{\mathrm{Fn}} \cdots \mathrm{OC}_{\mathrm{Boc} / \mathrm{Ac}} \mathrm{IHBs}$ enabled the peptide chain to fold into $\beta$-turn-like structure (Figure 29).

The conformational pattern established in solution persisted in the solid state as well and it was accompanied by favorable intermolecular hydrogen bonds in the formation of infinite zig-zag chains (Figure 30).

The ferrocene conjugates $\mathbf{4 8}$ and $\mathbf{4 9}$ were screened in vitro for their potential anticancer activity in HepG2 human liver carcinoma cells and Hs578T human breast cancer cells (Figure 31). Although the both tested compounds were founded to adopt the same conformational pattern, the peptide $\mathbf{4 8}$ displayed the improved bioactivity, most likely due to its increased lipophilicity $\left(R_{\mathrm{f}}=0.51\right)$ in comparison to the more polar 49 $\left(R_{\mathrm{f}}=0.12\right)$. 

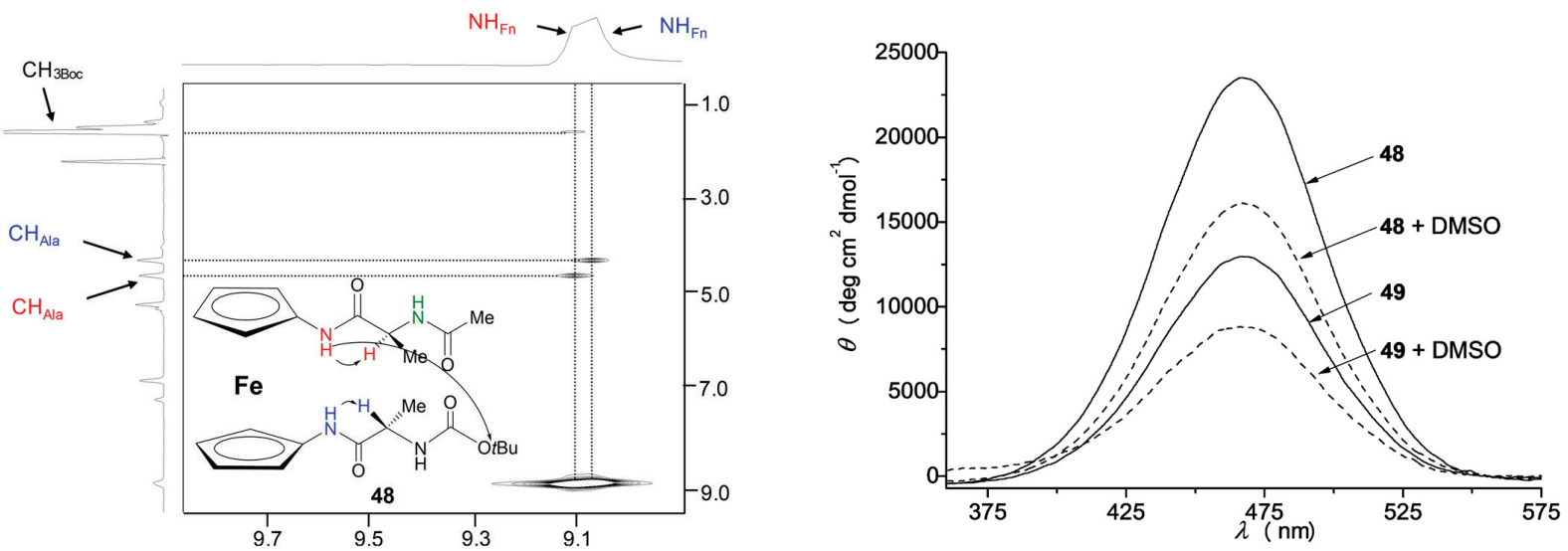

Figure 28. The interchain NOE connectivities between $C$ - and $\mathrm{N}$-termini of 48 (left) and Cotton effects in chirality-organized ferrocene peptides 48 and 49 in $\left.\mathrm{CH}_{2} \mathrm{Cl}_{2}\left[(-) \mathrm{c}=1 \times 10^{-3} \mathrm{M}\right)\right]$ and $\mathrm{CH}_{2} \mathrm{Cl}_{2}\left(\mathrm{c}=1 \times 10^{-3} \mathrm{M}\right)$ containing $20 \%$ of DMSO (---) (right).

(a)

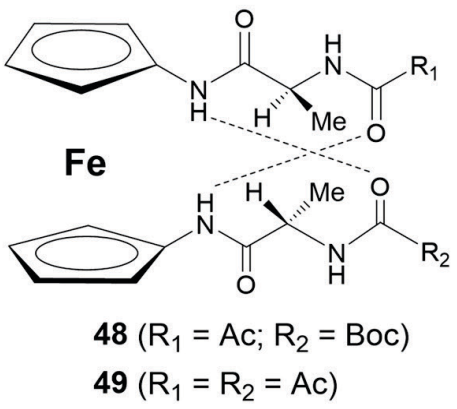

(b)

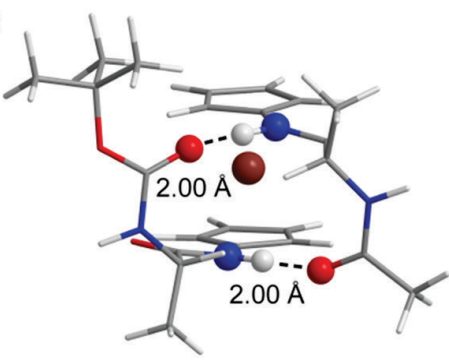

48

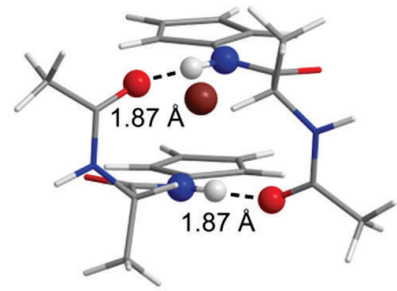

49

Figure 29. (a) IHB patterns and (b) optimized geometries of the most stable conformers based on computational study for peptides 48 and 49
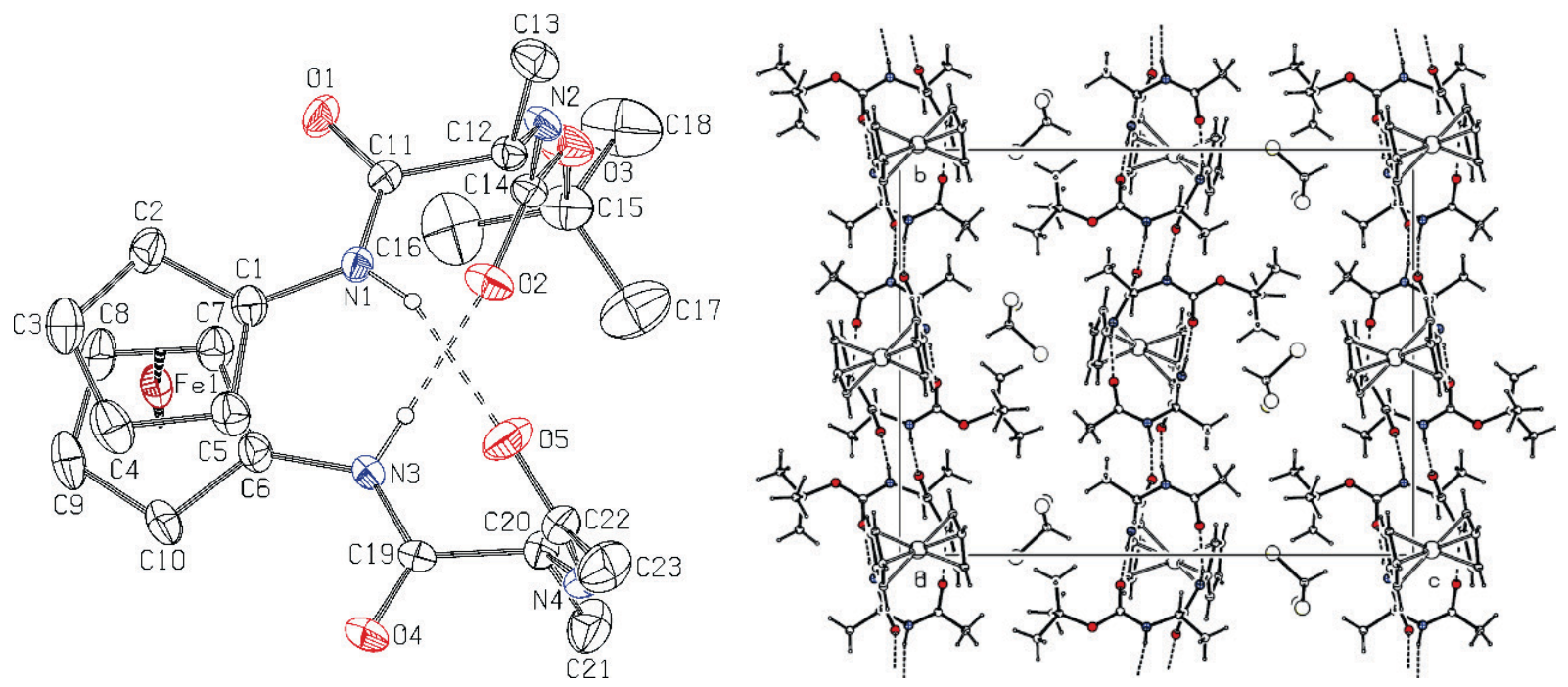

Figure 30. A molecular structure of bioconjugate 48 (left) and crystal packing diagram showing intramolecular and intermolecular $\mathrm{N}-\mathrm{H} \cdots \mathrm{O}$ hydrogen bonds (right). 

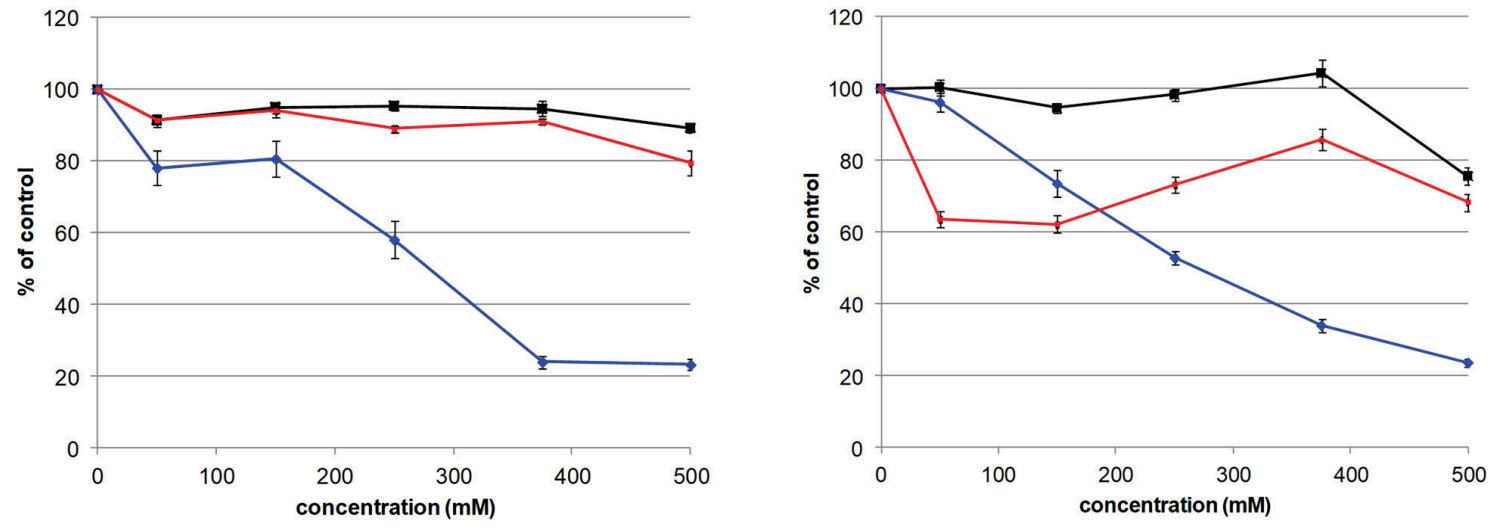

$\rightarrow$ ferrocene $\rightarrow 48 \rightarrow 49$

Figure 31. In vitro anti-proliferative effect of ferrocene and ferrocene conjugates 48 and 49 against HepG2 human liver carcinoma cells (left) and Hs578T human breast cancer cells (right). The lines connecting the measured points are drawn to enhance clarity.

\section{Bioconjugates of Ferrocene-1,1'-diamine with Homo- and Heterochiral Pro-Ala Sequences (62-65 and 69-72)}

Recently, we reported the synthesis of the peptides 62-65 and 69-72 that contain Ala-Pro sequences coupled to $\mathrm{NH}-$ derivatized cyclopentadienyl (Cp) rings. ${ }^{[36]}$ In order to examine the influence of the backbone chirality and $\mathrm{N}$ terminal groups on conformational properties, the synthesized peptides were designed to contain homo- or heterochiral Ala-Pro sequences with different $\mathrm{N}$-terminal groups i.e. the bulky Boc or sterically less demanding Ac functionality.

The peptides 62-65 were prepared by using the same synthetic approach applied for the synthesis of their lower homologues $\mathbf{4 8}$ and $\mathbf{4 9}$ (Scheme 8), while the symmetrically disubstituted peptides 69-72 were prepared following the procedure applied for the synthesis of their lower homologues Va ${ }^{[34]}$ (Scheme 9).

The capacity for turn formation was explored by concentration-dependent IR spectroscopy and concentration-, temperature- and solvent-dependent NMR studies. The distinct bands at $\sim 3430 \mathrm{~cm}^{-1}$ and $\sim 3250-3300 \mathrm{~cm}^{-1}$ in solution state IR spectra of the examined peptides suggested the presence of both free and associated $\mathrm{NH}$ groups. The blue-shifted amide I bands $\left(\sim 1710 \mathrm{~cm}^{-1}\right)$ observed in IR spectra of Boc-peptides 62, 63 and 72 suggested the alteration of the conformational properties in comparison to Ac-peptides 64 and $\mathbf{6 5}$. The relative intensities of free and associated amide bands of the tested peptides were maintained during dilution, owing to the intramolecular engagement of hydrogen-bonded amide groups.

The two kinds of resonances were observed in NMR spectra of the goal compounds: the downfield shifted resonances of $\mathrm{NH}_{\mathrm{Fn}}$ groups ( $\delta \gtrsim 9.2 \mathrm{ppm}$ ) that suggested their involvement in $\mathrm{HB}$ and upfield shifted resonances of Ala- $\mathrm{NH}_{\text {Boc/Ac }}(\delta \sim 5-6.5 \mathrm{ppm})$ that suggested the lower potential to experience hydrogen-bonding.

The IR findings on non-involvement of the examined peptides in intermolecular aggregation were supported by the sharp signals and non-affected ( $\mathrm{NH}_{\mathrm{Fn}}$ and Ala- $\mathrm{NH}_{\text {Boc }}$ ) or slightly affected chemical shifts (Ala- $\mathrm{NH}_{\mathrm{Ac}}$ ) upon dilution up to 50-fold (Figure 32a). Furthermore, no significant upfield shift of the amide protons was observed upon successive heating of $1 \mathrm{mM}$ solutions of the examined peptides in $\mathrm{CDCl}_{3}$ in the range of $258-328 \mathrm{~K}$, certainly due to their involvement in strong IHBs or non-involvement in hydrogen bonding at all (Figure 32b). While the amide resonances belonging to the conformers of the homochiral peptides remained resolved at increased temperature, the signals of heterochiral peptides underwent partial coalescence, suggesting conformational differences imparted by bacbone chirality.

The larger temperature dependencies of the concentration-independent $\mathrm{NH}_{\mathrm{Fn}}$ protons of peptides 62 65 indicated that they were initially shielded owing to the hydrogen bonding engagement, but became exposed to the solvent upon unfolding of the ordered structures at increased temperatures. The distinct conformational patterning of homo- and heterochiral peptides was strongly suggested by different temperature dependencies (Figure $32 \mathrm{~b})$. The concentration-independent D-Ala- $\mathrm{NH}_{\mathrm{Ac}}$ in heterochiral peptides 63 and $\mathbf{6 5}$ exibited the larger temperature dependencies due to their participation in intramolecular hydrogen bonding. At the same time, the smaller temperature dependencies of the upfield shifted LAla- $\mathrm{NH}_{\mathrm{Ac}}$ in homochiral peptides $\mathbf{6 2}$ and $\mathbf{6 4}$ reflect their non-involvement in HBs (Figure 33). 


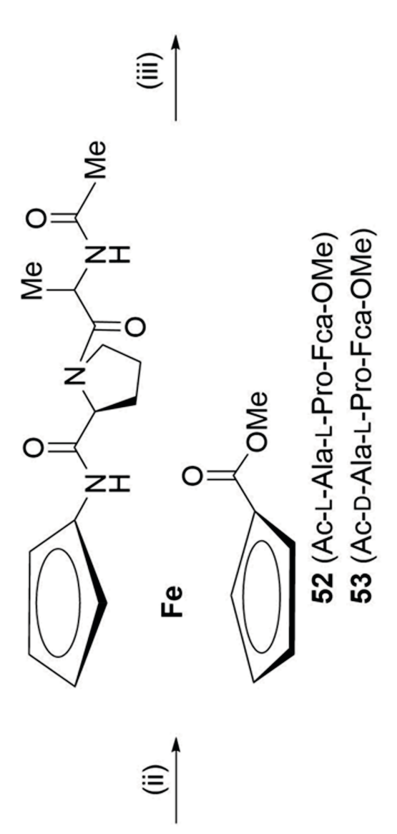<smiles>[CH]</smiles>

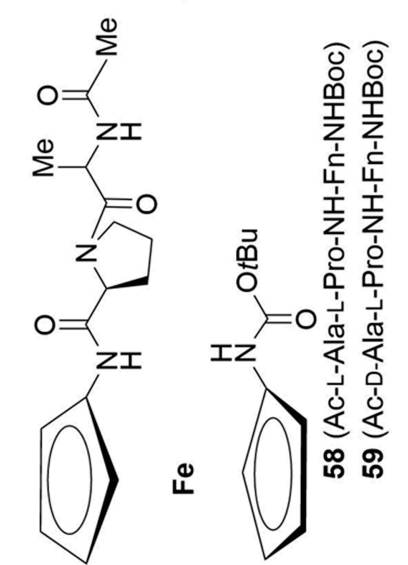

$\Sigma \uparrow$

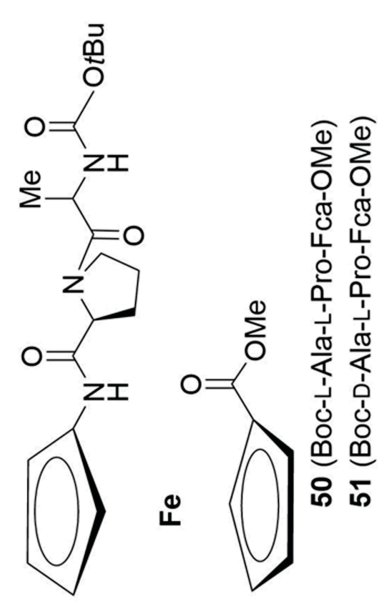

$\cong \uparrow$

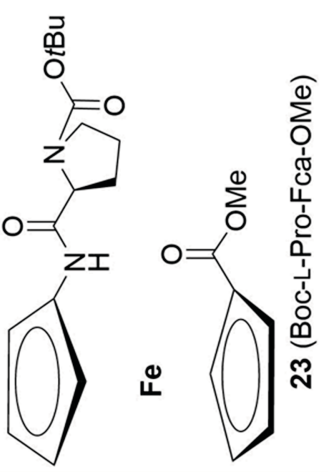

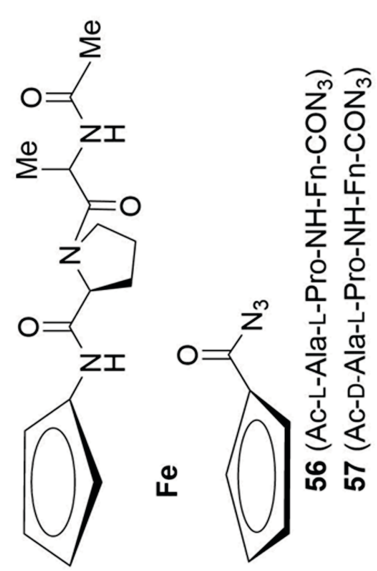

$\geqq \hat{\imath}$

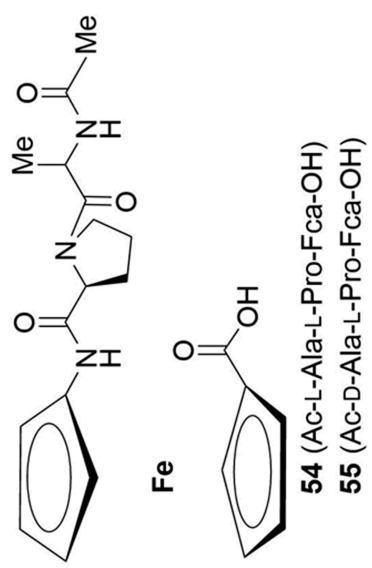

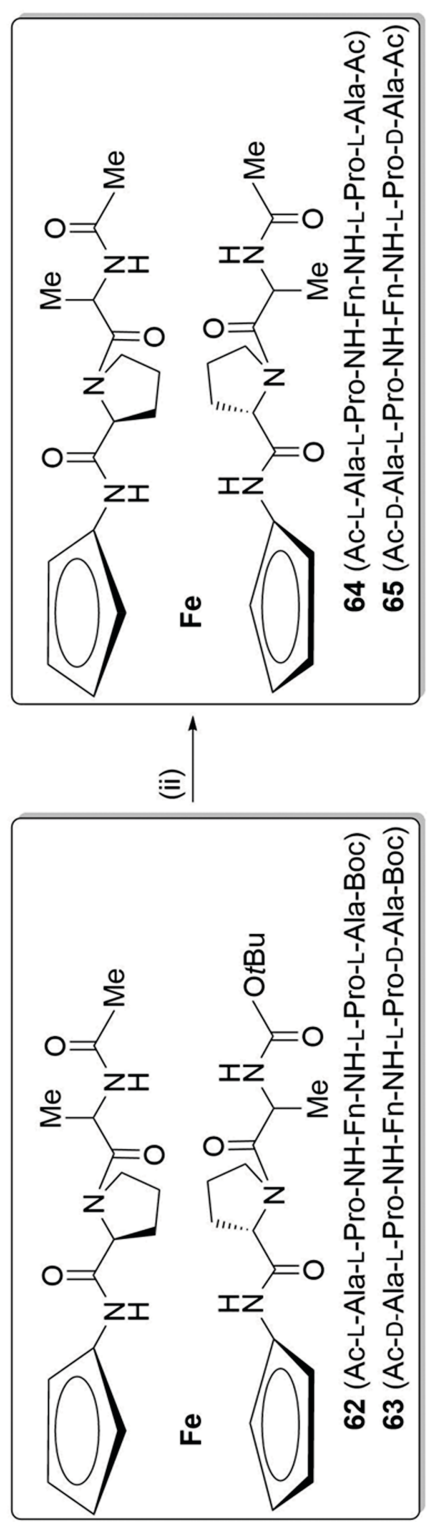

$\cong \uparrow$<smiles>C[C](C)C(C)=O</smiles>

ชิ

ㅇํํ 은

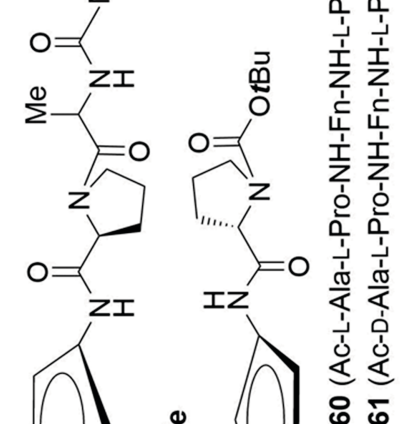

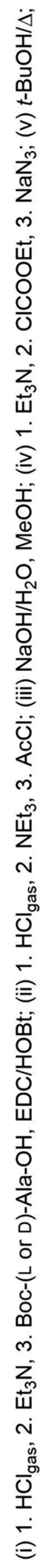




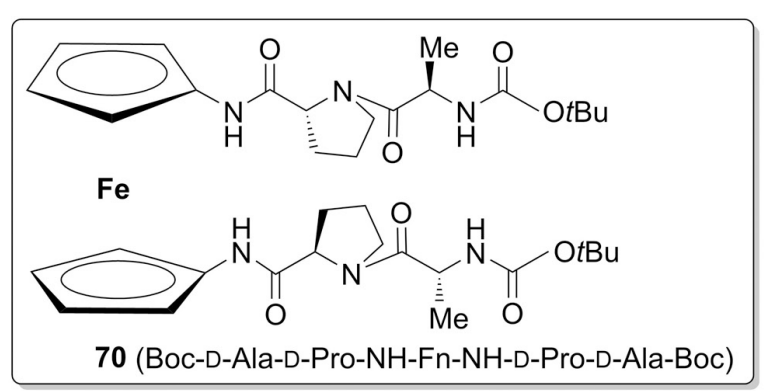

70 (Boc-D-Ala-D-Pro-NH-Fn-NH-D-Pro-D-Ala-Boc)

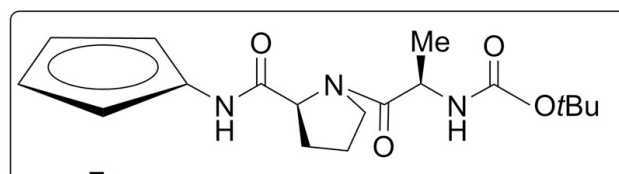

$\mathrm{Fe}$

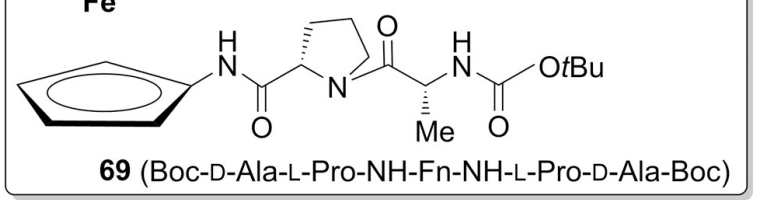

69 (Boc-D-Ala-L-Pro-NH-Fn-NH-L-Pro-D-Ala-Boc) (iv)<smiles>O=C(O)c1ccccc1</smiles>

$\mathrm{Fe}$<smiles>O=C(O)c1ccccc1</smiles>

66 $\stackrel{\text { (i) }}{\longrightarrow}$

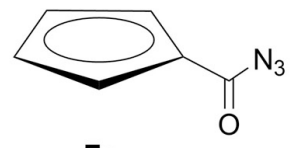

$\mathrm{Fe}$

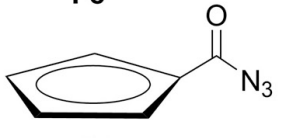

67 $\stackrel{\text { (ii) }}{\longrightarrow}$<smiles>CCCCOC(=O)Nc1ccccc1</smiles>

$\mathrm{Fe}$<smiles>CCCCOC(=O)Nc1ccccc1</smiles>

68

(iii)

(v)

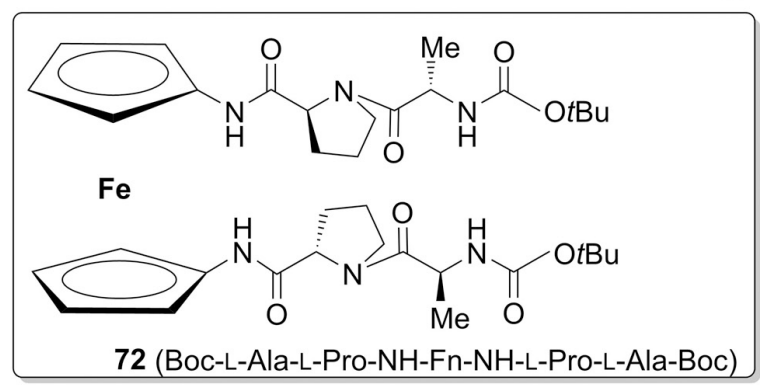

(vi)

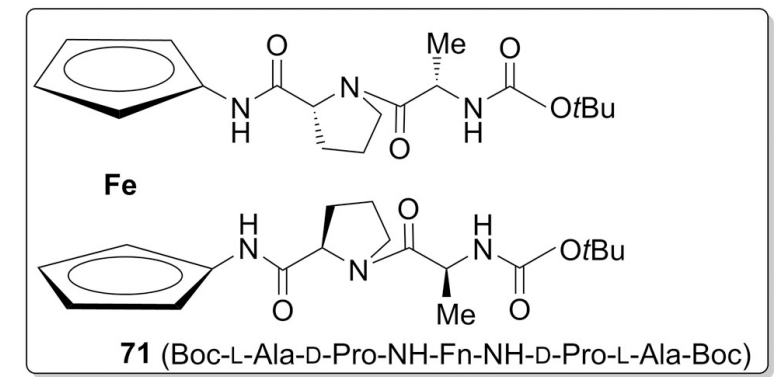

(i) 1. $\mathrm{Et}_{3} \mathrm{~N}, 2 . \mathrm{ClCOOEt}, 3 . \mathrm{NaN}_{3}$; (ii) $t-\mathrm{BuOH} /$; (iii) 1. TFA, 2. $\mathrm{Et}_{3} \mathrm{~N}$, 3. Boc-D-Ala-L-Pro-OH, HBTU/HOBt;

(iv) 1. TFA, 2. $\mathrm{Et}_{3} \mathrm{~N}$, 3. Boc-D-Ala-D-Pro-OH, HBTU/HOBt; (v) 1. TFA, 2. Et ${ }_{3} \mathrm{~N}$, 3. Boc-L-Ala-D-Pro-OH, HBTU/HOBt;

(vi) 1. TFA, 2. $\mathrm{Et}_{3} \mathrm{~N}, 3$. Boc-L-Ala-L-Pro-OH, HBTU/HOBt.

Scheme 9. Synthesis of symmetrically disubstituted ferrocene-peptide conjugates 69-72 containing homo- or heterochiral AlaPro sequences.

The different conformational behaviour of intramolecularly engaged $\mathrm{NH}_{\mathrm{Fn}}$ protons of homo- and heterochiral peptides was additionally supported by DMSO titration experiments (Figure 34). While the $\mathrm{NH}_{\mathrm{Fn}}$ protons of the homochiral peptides $\mathbf{6 2 , 6 4}$ and $\mathbf{7 2}$ moved slightly downfield in the presence of DMSO, the $\mathrm{NH}_{\mathrm{Fn}}$ protons of the heterochiral peptides $\mathbf{6 3}$ and $\mathbf{6 5}$ moved slightly upfield. A common feature of their Ala- $\mathrm{NH}_{\mathrm{Boc} / \mathrm{Ac}}$ groups was a solvent exposure observable through a high degree of solvent sensitivity $(\Delta \delta \sim 1.28-1.9)$ that emerged from their non-involvement in hydrogen bonding or involvement in only weak hydrogen bonds. Moreover, unlike the heterochiral counterparts, the portion of the trans/trans conformers of the homochiral peptides remained almost unchanged upon addition of DMSO.
Although the amide resonances of homo- and heterochiral peptides displayed different temperature and solvent dependences, their common conformational feature was involvement of $\mathrm{NH}_{\mathrm{Fn}}$ protons in $\mathrm{IHBs}$. Bearing in mind the number and position of hydrogen-bond accepting carbonyl groups, the tentative conformations of the examined peptides could, therefore, rely on both intraand interstrand IHBs. The interstrand NOE contacts observed in spectra of orthogonally protected peptides $62\left(\mathrm{NH}_{\mathrm{Fn}}{ }^{\mathrm{b}} \rightarrow\right.$ Ala- $\left.\mathrm{NH}_{\mathrm{Ac}}\right)$ and $63\left(\mathrm{NH}_{\mathrm{Fn}}{ }^{\mathrm{b}} \rightarrow\right.$ Ala- $\mathrm{NH}_{\mathrm{Ac}}$ and $\mathrm{NH}_{\mathrm{Fn}}{ }^{\mathrm{a}} \rightarrow$ Ala- $\mathrm{NH}_{\text {Boc }}$ ) corroborated the presence of interstrand IHBs. However, the NOE contacts $\mathrm{NH}_{\mathrm{Fn}} \rightarrow \mathrm{Me}_{\mathrm{Ac}}$ and $\mathrm{NH}_{\mathrm{Fn}} \rightarrow$ Ala- $\mathrm{NH}_{\mathrm{Ac}}$ detected in spectra of symmetrically disubstituted Ac-protected peptides 64 and 65, and 
(a)

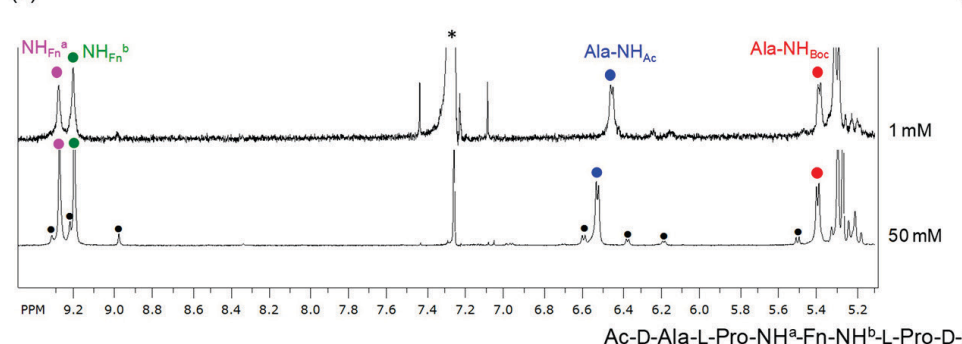

(b) $\delta(\mathrm{ppm})$
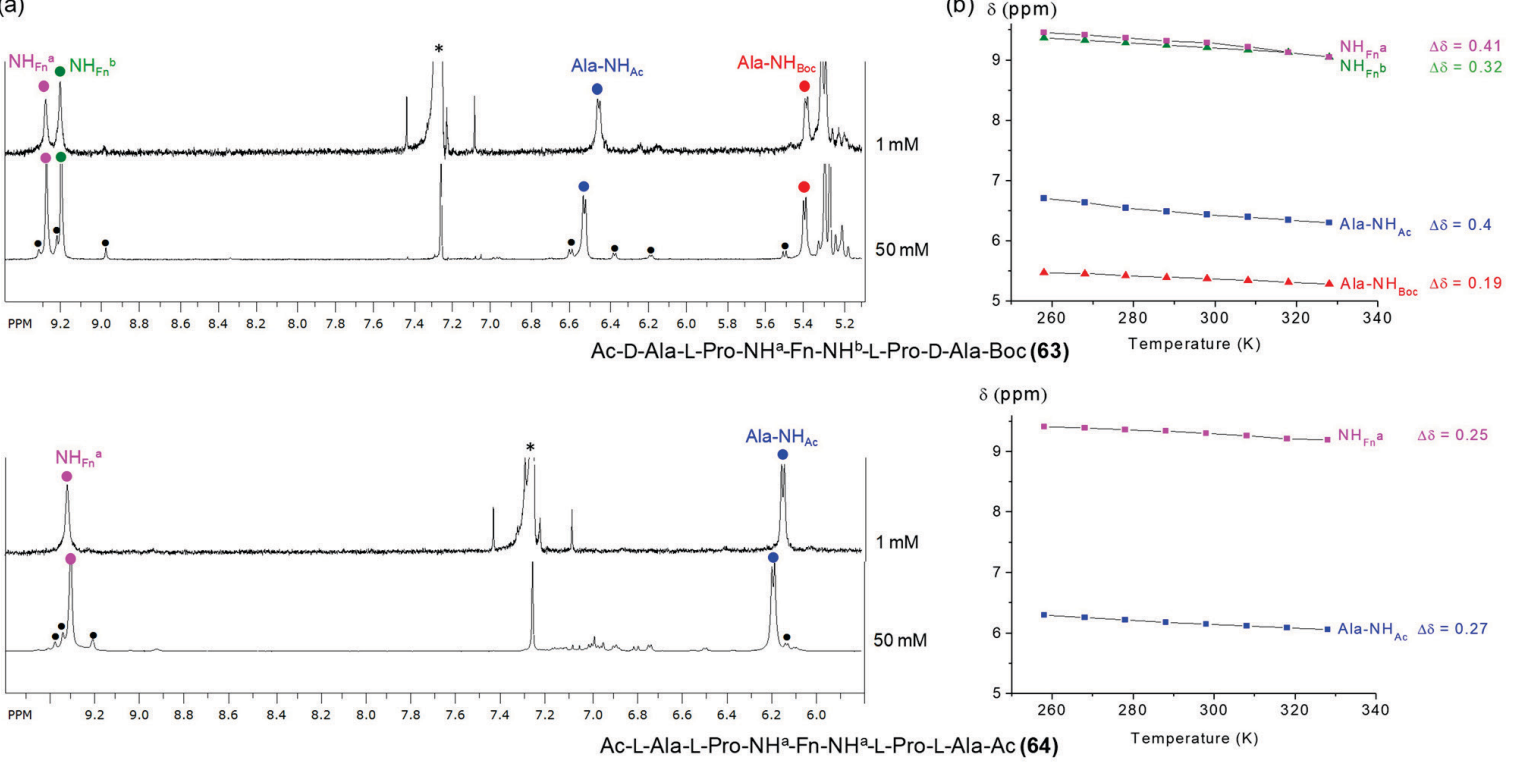

Ac-L-Ala-L-Pro-NHa-Fn-NH'a-L-Pro-L-Ala-Ac (64)
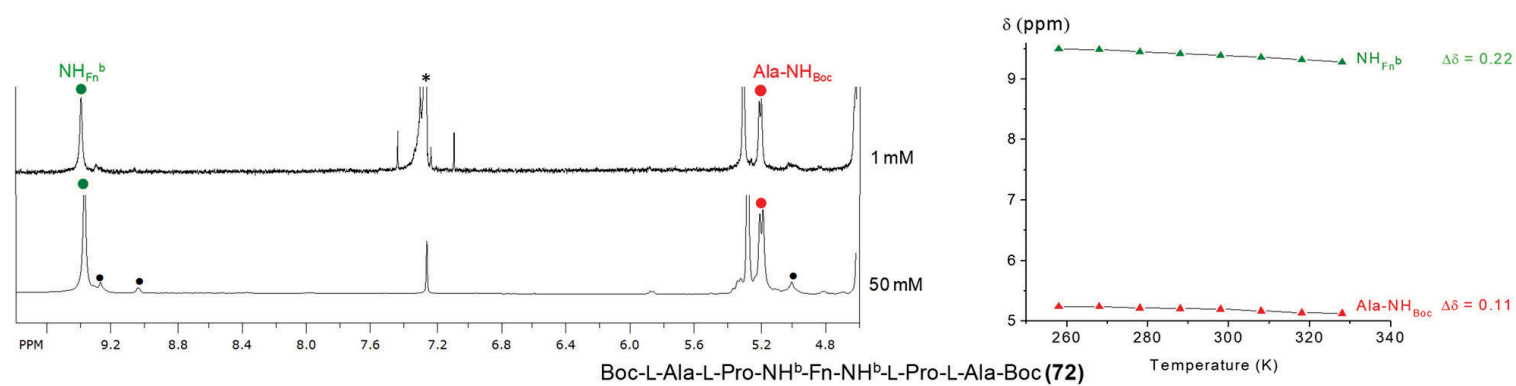

Figure 32. (a) Concentration dependence of NH chemical shifts of heterochiral peptide 63 and homochiral peptides 64 and 72 (* residual $\mathrm{CDCl}_{3}, \bullet$ trans/cis, cis/trans and cis/cis rotamers), (b) Temperature dependence of $\mathrm{NH}$ chemical shifts of heterochiral

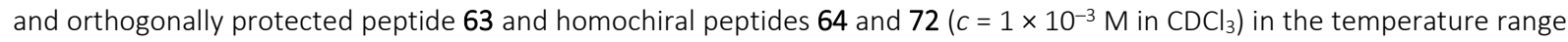
of $258-328 \mathrm{~K}$. The corresponding chemical shift differences $(\Delta \delta)$ are indicated on the right.

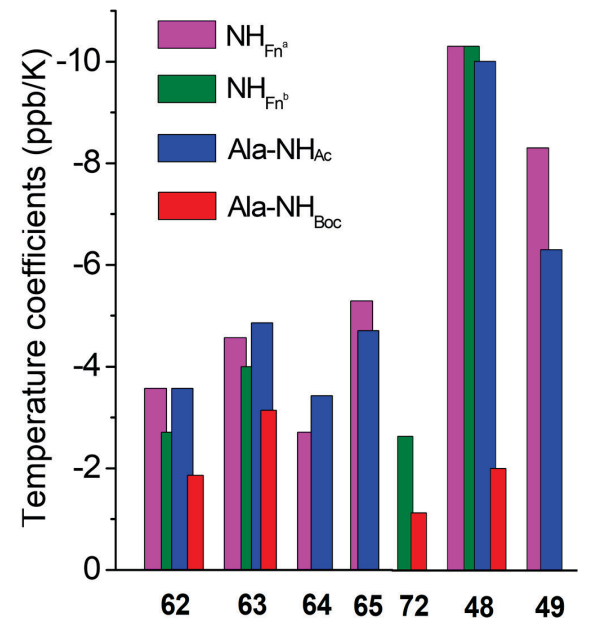

Figure 33. Amide temperature coefficients of the homochiral peptides 62,64 and 72, heterochiral peptides 63 and 65 and their lower homologues 48 and $49\left(c=1 \times 10^{-3} \mathrm{M}\right.$ in $\left.\mathrm{CDCl}_{3}\right)$.
$\mathrm{NH}_{\mathrm{Fn}} \rightarrow$ Ala- $\mathrm{NH}_{\text {Boc }}$ visible in spectrum of symmetrically disubstituted Boc-protected peptide 72, might account for both intra- and interstrand IHBs (Figure 35).

The strong positive Cotton effects observed in $C D$ spectra of the examined compounds strongly suggested the high level of chiral organization i.e. P-helicity, established through interstrand hydrogen bonding (Figure 36). The different loss of $C D$ activity in the presence of $50 \%$ of DMSO indicated the different hydrogen bonds strength. The heterochiral peptide $\mathbf{6 5}$, founded to be the most solventexposed due to the largest DMSO-induced shift of its amide protons, conserved only $35 \%$ of initial CD activity. Similarly, the other tested heterochiral peptide $\mathbf{6 3}$ maintained $39 \%$ of its $C D$ activity. The homochiral peptides $\mathbf{6 4}$ and $\mathbf{7 2}$ were founded to be more stable, preserving $57-89 \%$ of the initial CD activity upon addition of $50 \%$ of DMSO.

The quite different DMSO-behaviour of concentrationand temperature-independent $\mathrm{NH}_{\mathrm{Fn}}$ protons of homo- $(\mathbf{6 2}, \mathbf{6 4}$, 72) and heterochiral peptides (65) implied the different 
(a)

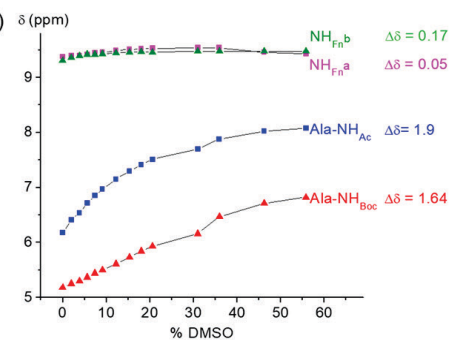

Ac-L-Ala-L-Pro-NH ${ }^{\mathrm{a}}-\mathrm{Fn}-\mathrm{NH}^{\mathrm{b}}$-L-Pro-L-Ala-Boc (62)

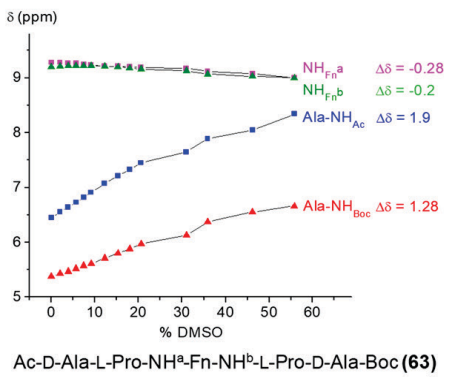

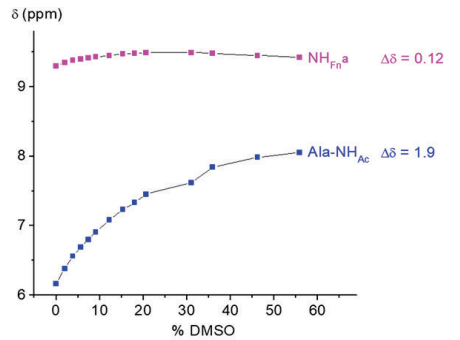

Ac-L-Ala-L-Pro-NH'a-Fn-NH'-L-Pro-L-Ala-Ac (64)

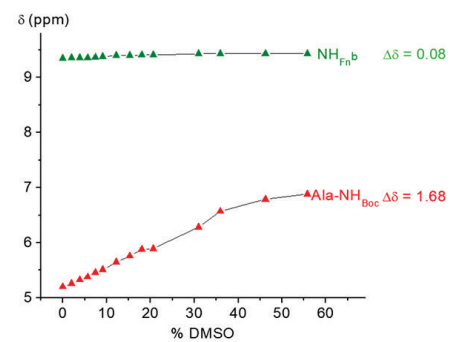

Boc-L-Ala-L-Pro-NH ${ }^{\mathrm{b}}-\mathrm{Fn}-\mathrm{NH}^{\mathrm{b}}$-L-Pro-L-Ala-Boc (72)

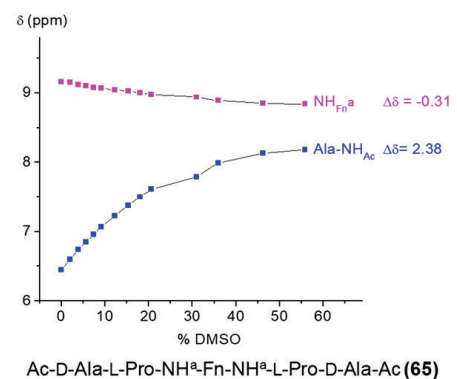

Figure 34. Solvent dependence of NH chemical shifts of (a) homochiral peptides 62,64 and 72 and (b) heterochiral peptides 63 and 65 at increasing concentrations of $d_{6}$-DMSO in $\mathrm{CDCl}_{3}(c=25 \mathrm{mM}, 298 \mathrm{~K})$ to probe exposed vs. hydrogen-bonded amides.

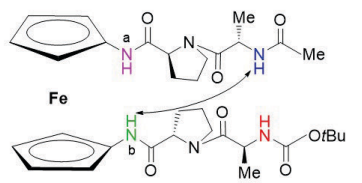

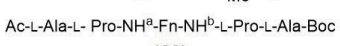

(62)

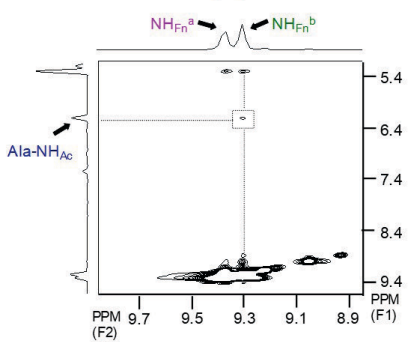

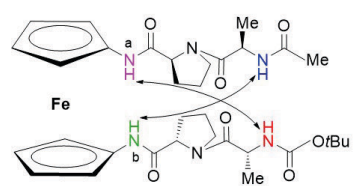

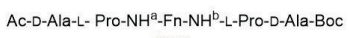

(63)

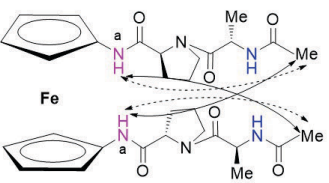

Ac-L-Ala-L- Pro-NH ${ }^{a}$-Fn-NH ${ }^{\mathrm{a}-L-P r o-L-A l a-A C}$

(64)
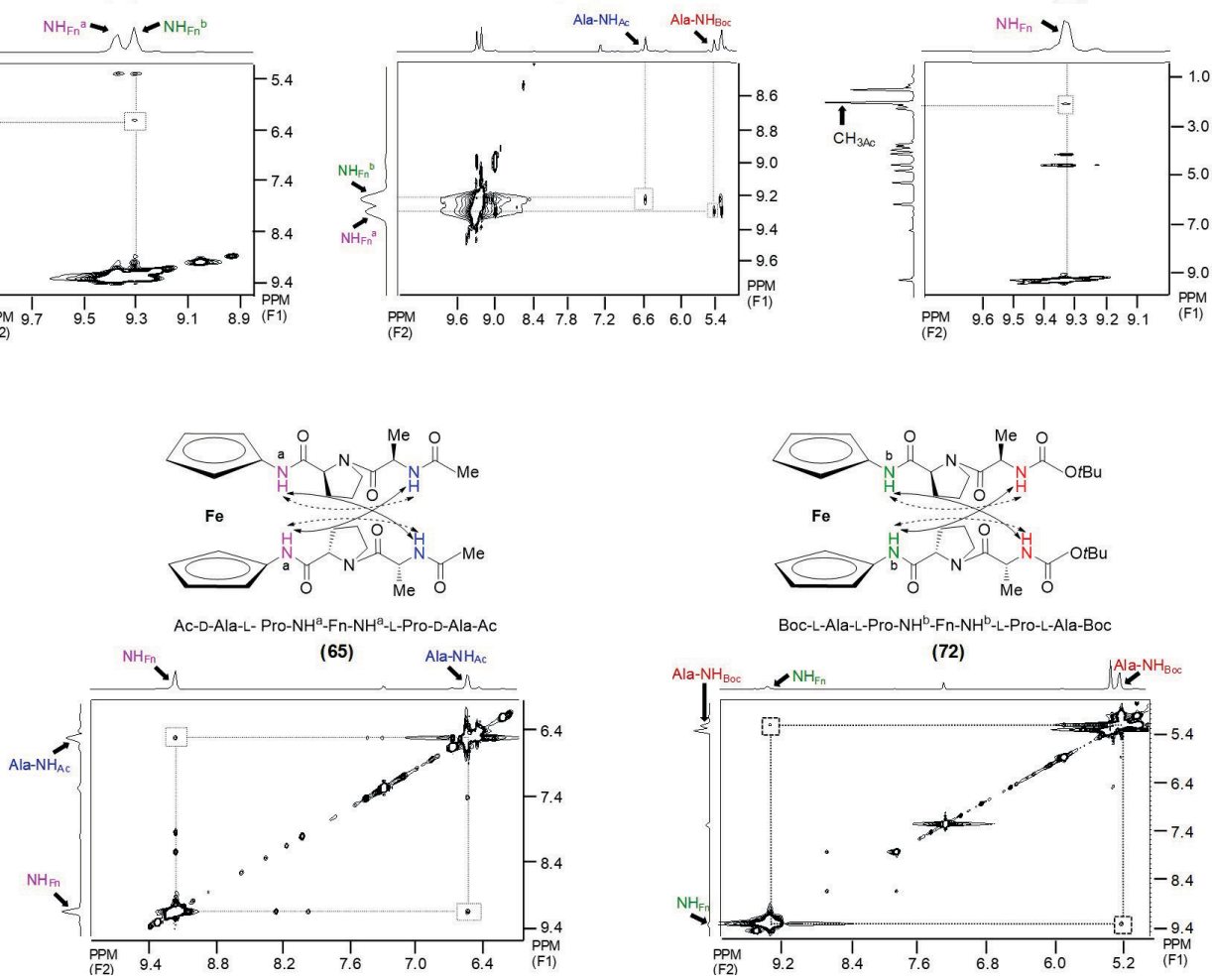

Boc-L-Ala-L-Pro-NH ${ }^{b}$-Fn-NH ${ }^{b}$-L-Pro-L-Ala-Boc

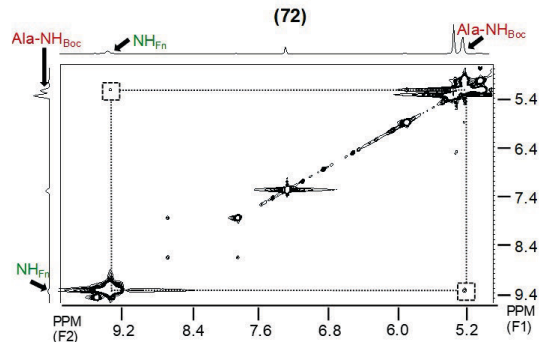

Figure 35. The interstrand NOE connectivities in spectra of 62-65 and 72 are depicted with arrows. 


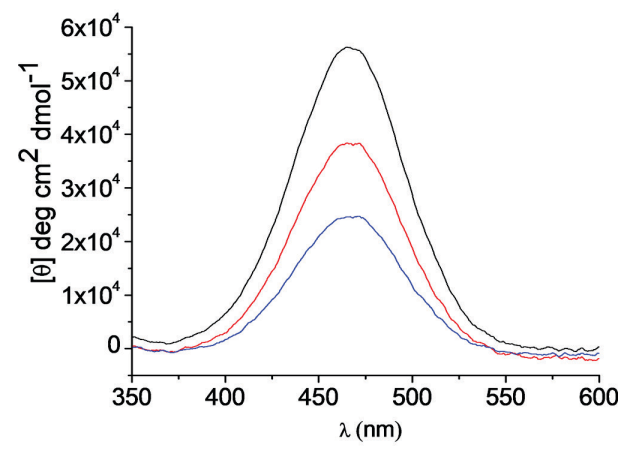

Ac-L-Ala-L-Pro-NH-Fn-NH-L-Pro-L-Ala-Boc

(62)

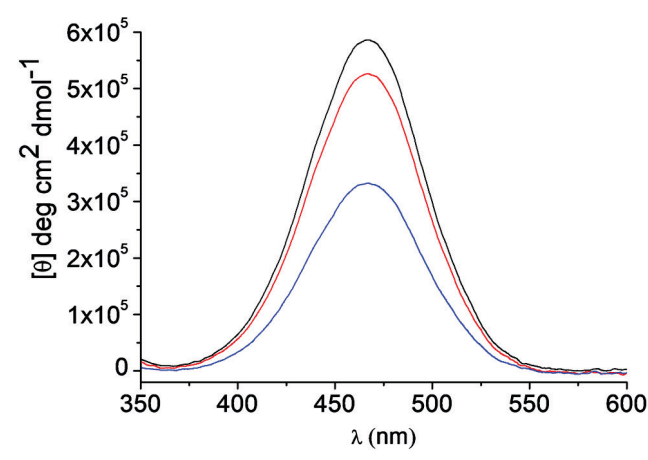

Ac-L-Ala-L-Pro-NH-Fn-NH-L-Pro-L-Ala-Ac

(64)

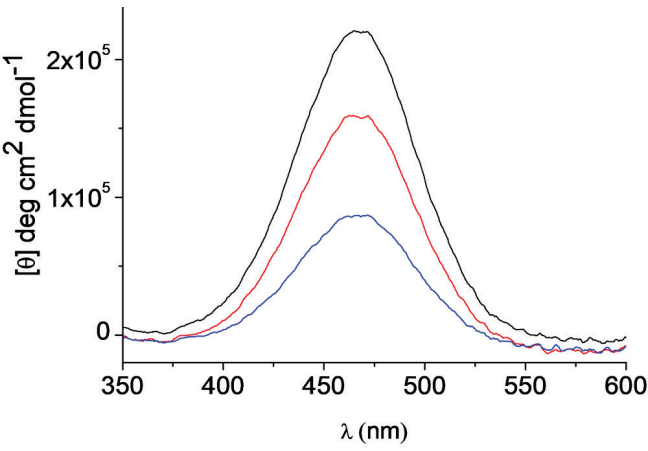

Ac-D-Ala-L-Pro-NH-Fn-NH-L-Pro-D-Ala-Boc

(63)

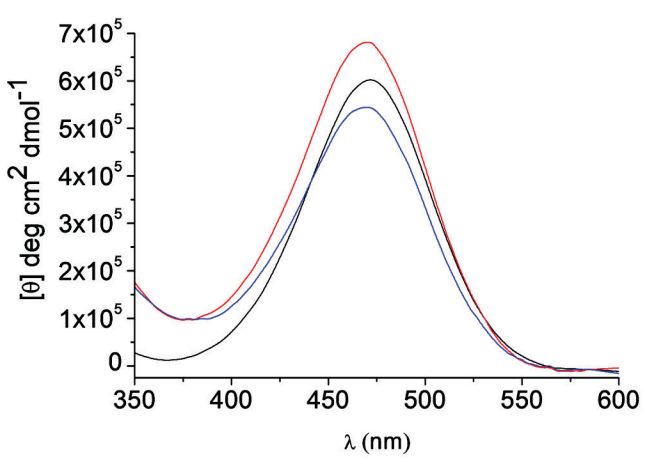

Boc-L-Ala-L-Pro-NH-Fn-NH-L-Pro-L-Ala-Boc

(72)

Figure 36. The Cotton effects in chirality-organized ferrocene peptides $62-64$ and 72 in solution $\left\{\mathrm{CH}_{2} \mathrm{Cl}_{2}\left[(-) c=1 \times 10^{-3} \mathrm{M}\right)\right.$, $\mathrm{CH}_{2} \mathrm{Cl}_{2}\left(c=1 \times 10^{-3} \mathrm{M}\right)$ containing $20 \%$ of DMSO $(-)$ and $\mathrm{CH}_{2} \mathrm{Cl}_{2}\left(c=1 \times 10^{-3} \mathrm{M}\right)$ containing $50 \%$ of DMSO $\left.\left.(-)\right]\right\}$.
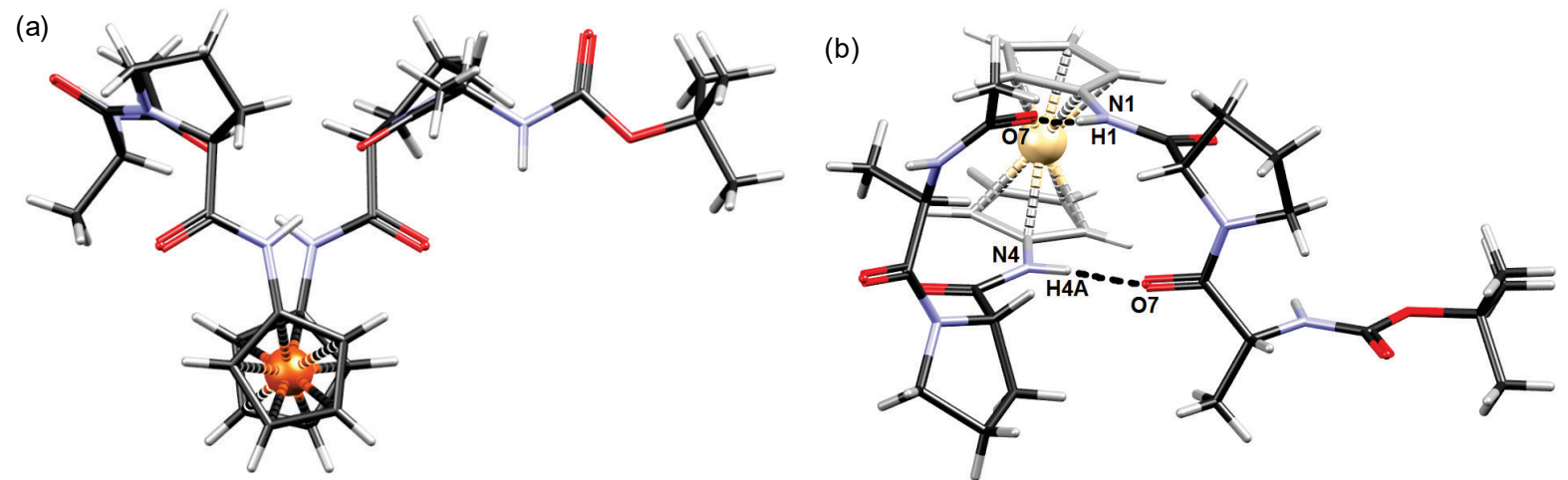

Figure 37. Conformation of Ac-D-Ala-L-Pro-NH-Fn-NH-L-Pro-D-Ala-Boc (63). (a) top-down view revealing $P$-helicity and torsion between peptide chains, (b) a side-view showing conformation of peptide chains stabilized by IHBs.

conformational patterns established through IHBs of different kinds and strength. Considering that the less stable conformations arose if the hydrogen bonds were established within the same strand, ${ }^{774,77]}$ the engagement of DMSO-sensitive $\mathrm{NH}_{\mathrm{Fn}}$ of peptide 65 in intrastrand IHBs was strongly suggested.
The $P$-helicity indicated by $\mathrm{CD}$ data was also determined in the crystal structure of compound 63 . The two IHBs between the podant peptide strands forming one ten-membered ( $\beta$-turn-like) and one thirteen-membered ring were observed (Figure 37). 


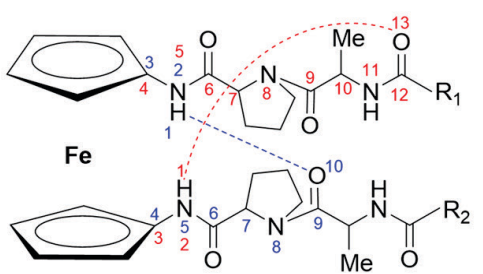

A

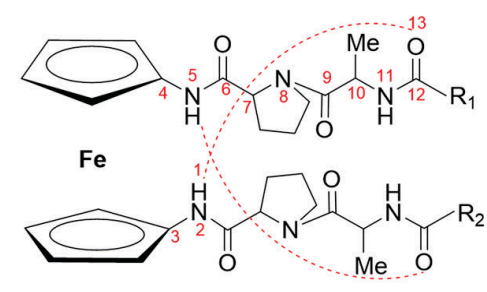

B

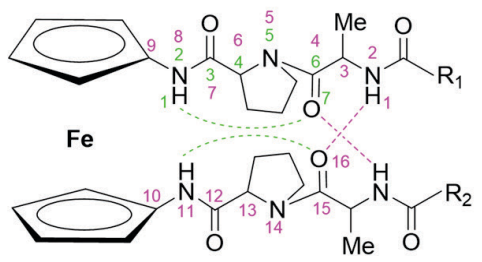

C

Figure 38. The intramolecular hydrogen bonding patterns observed in homochiral peptides 62,64 and 72 (patterns A and B) and heterochiral peptides 63 and 65 (pattern C). 62 and $63\left(R_{1}=M e, R_{2}=O t B u\right), 64$ and $65\left(R_{1}=R_{2}=M e\right), 72\left(R_{1}=R_{2}=0 t B u\right)$. Numerations of the corresponding hydrogen bonded rings are displayed.

The DFT study corroborated the different conformational behaviour suggested by spectroscopic analyses (Figure 38). The homochiral peptides 62, 64 and $\mathbf{7 2}$ were prone to form simultaneous intramolecular hydrogen bonding engagement of $\mathrm{NH}_{\mathrm{Fn}}$, influenced by the steric bulkiness of the $\mathrm{N}$-terminal group. The Ac-derivative $\mathbf{6 4}$ adopted the two thirteen-membered interstrand hydrogen bonded rings (pattern B). In the peptides 62 and 72, containing one or both bulky Boc-groups instead of Ac, one thirteen-membered hydrogen bonded ring was preserved while another was replaced with ten-membered ring (pattern A).

The L- to D-Ala exchange in heterochiral peptides 63 and $\mathbf{6 5}$ strongly influenced their conformational patterning: the thirteen-membered ring, most commonly observed in the heterochiral counterparts, was replaced by the highly symmetrical intramolecular hydrogen bonding pattern made of seven-membered intrastrand and sixsteenmembered interstrand hydrogen bonds (pattern $\mathbf{C}$ ).

Considering the revealed turn-inducing potential of Fcda scaffold, our future work will be directed to the conjugates of Fcda with biologically valuable branchedchain amino acids.

\section{CONCLUSIONS}

This review is aimed to underline the biological and conformational potential of ferrocene bioconjugates synthesized in our group. Although we have been mainly focused on the conformational behaviour of ferrocene peptidomimetics, the attention was also paid to the potentially biologically active ferrocene compounds.

The biological evaluation revealed both the cytotoxic and hemagglutination inhibition potential of ferrocene bioconjugates. The conjugation of resveratrol with ferrocene was shown to contribute to the improved cytotoxicity against liver cancer cells HepG2, whilst significantly lower cytotoxicity on normal ovary CHO-K1 cells was observed. The interesting biological phenomenon named hormesis was observed for oxalamide-bridged ferrocene which displayed proliferative effect on normal kidney HEK293T cells followed with cytotoxic activity against tumour cervical HeLa cells. Besides the cytotoxic activity, ferrocenes were also tested as inhibitors of FimHmediated hemagglutination. Among the so far tested ferrocene conjugates with mannopyranoside acid, equipped with aglycon alkyl chains of different length ( $n=$ $0-5$ ), the most pronounced increment of inhibitory activity was observed for those which contains butyl group.

The major part of our research was aimed to study the conformational behaviour of ferrocene peptidomimetics. For that purpose, three different ferrocene scaffolds $(-\mathrm{NH}-\mathrm{Fn},-\mathrm{NH}-\mathrm{Fn}-\mathrm{CO}-$ and $-\mathrm{NH}-\mathrm{Fn}-$ $\mathrm{NH}-$ ) were employed to conjugate with various amino acid sequences and the obtained peptides were subjected to detailed conformational analysis based on spectroscopic measurements (IR, NMR and CD) and DFT study.

The results of conformational analysis of peptides 25-28 [Y-L-Ala-NH-Fn-COOMe (25, Y = Boc; $27 ; \mathrm{Y}=\mathrm{Ac})$ and $\mathrm{Y}$-D-Ala-NH-Fn-COOMe (26, $\mathrm{Y}=\mathrm{Boc} ; \mathbf{2 8} ; \mathrm{Y}=\mathrm{AC})$ ] suggested the presence of intra- [7-membered $\mathrm{NH}_{\mathrm{Fn}} \cdots \mathrm{OC}_{\mathrm{AC}} \mathrm{HB}$-ring $(\gamma$ turn) and 5-membered $\mathrm{NH}_{F n} \cdots \mathrm{N}_{\text {Ala }} \mathrm{HB}$-ring] and interstrand IHBs (9-membered $\mathrm{NH}_{\text {Ala }} \cdots \mathrm{OC}_{\mathrm{Fn}}$ HB-ring). The alanine chirality was not observed to influence the hydrogen bonding patterning, while the presence of Boc group was founded to interfere with hydrogen bonding to a lesser extent. The results of computational analysis corroborated the IHB motifs predicted by experimental data.

The medium-strength hydrogen bond, established between $\mathrm{NH}_{\mathrm{Fn}}$ and urethane carbonyl, was found in the lowest homologues of nonsymmetric ferrocene peptides 33-35 (Boc-AA-NH-Fn-COMe; AA = Gly, L-Ala, L-Val) and their monosubstituted analogues 30-32 (Boc-AA-NH-Fn; $A A=$ Gly, L-Ala, L-Val). $\mathrm{N}$-terminal elongation of $\mathbf{3 0 - 3 5}$ gave mono- 36-38 [Boc-(AA) $)_{2}-\mathrm{NH}-\mathrm{Fn} ; \mathrm{AA}=\mathrm{Gly}$, L-Ala, L-Val] and disubstituted ferrocene peptides 39-41 [Boc-(AA) ${ }_{2}-\mathrm{NH}-$ Fn-COMe; $A A=$ Gly, L-Ala, L-Val]. According to computational analysis, the lowest energy conformer of monosubstituted derivatives $\mathbf{3 6}-\mathbf{3 8}$ is stabilized by $\beta$-turnlike structure (10-membered $\mathrm{NH}_{\mathrm{Fn}} \cdots \mathrm{OC}_{\mathrm{Boc}} \mathrm{HB}$ ring). 
Additional hydrogen bond acceptor group (COMe) in the analogous 1-acetyl derivatives (39-41) enables them to form interchain hydrogen bonds and causes the destabilization of $\beta$-turn structures.

While the enantiomeric $\beta$-turns were found to be most stable conformations of homochiral derivatives $B o c-A A_{2}$ $\mathrm{AA}_{1}-\mathrm{NH}-\mathrm{Fn}\left(\mathbf{4 2}, \mathrm{AA}_{1}=\mathrm{L}-\mathrm{Ala}, \mathrm{AA}_{2}=\mathrm{L}-\mathrm{Pro} ; \mathbf{4 3}, \mathrm{AA}_{1}=\mathrm{D}-\mathrm{Ala}, \mathrm{AA}_{2}=\right.$ D-Pro), the change of the chirality of the amino acid at the $i+1$ position of $\beta$-turn causes its disruption in the solutions of the derived heterochiral peptides $44\left(\mathrm{AA}_{1}=\mathrm{L}-\mathrm{Ala}, \mathrm{AA_{2 }}=\mathrm{D}-\mathrm{Pro}\right)$ and $45\left(\mathrm{AA}_{1}=\mathrm{D}-\mathrm{Ala}, \mathrm{AA}_{2}=\mathrm{L}-\mathrm{Pro}\right)$ as suggested by the $\mathrm{CD}, \mathrm{NMR}$ spectroscopy and theoretical analysis.

Ferrocene-1,1'-diamine scaffold was found to induce the formation of two simultaneous 10-membered $\beta$-turn-like structures in peptides Ac-Ala-NH-Fn-NH-Ala-Boc (48) and $\mathrm{Fn}-(\mathrm{NH}-\mathrm{Ala}-\mathrm{Ac})_{2}$ (49), thus replicating hydrogen bonding pattern of peptide $\beta$-sheets. The same pattern was established in the solid state and was corroborated with DFT data.

The different conformational behaviour of homo(62, 64 and 72) and heterochiral peptides (63 and 65) comprised of $-\mathrm{NH}-\mathrm{Fn}-\mathrm{NH}$ - scaffold and Ala-Pro sequences was strongly suggested by spectroscopic analyses and corroborated with DFT studies. The Ac-derivative $\mathbf{6 4}$ adopted the two 13 -membered $\mathrm{NH}_{\mathrm{Fn}} \cdots \mathrm{OC}_{\mathrm{Ac}}$ interstrand hydrogen bonded rings. In the peptides $\mathbf{6 2}$ and 72, that contain one or both bulky Boc-groups instead of Ac, one 13membered hydrogen bonded ring was preserved while another was replaced with 10-membered interstrand ring $\left(\mathrm{NH}_{\mathrm{Fn}} \cdots \mathrm{OC}_{\mathrm{Ala}}\right)$. Upon L- to D-Ala exchange, the 13-membered ring, most commonly observed in the heterochiral conjugates, was replaced by the highly symmetrical intramolecular hydrogen bonding pattern made of two pairs of hydrogen bonds, 7-membered intrastrand $\mathrm{NH}_{\mathrm{Fn}} \cdots \mathrm{OC}_{\text {Ala }}$ and 16-membered interstrand $\mathrm{NH}_{\mathrm{Fn}} \cdots \mathrm{OC}_{\mathrm{Ala}}$ hydrogen bonds. The relationship observed between the backbone homo- or heterochirality, the hydrogen bonding acceptor ability of the $\mathrm{N}$-terminal groups and the hydrogen bonding patterning can be applied to tune the preferred hydrogen bonded ring size in the derived peptidomimetics.

Acknowledgments. We would like to express sincere gratitude to our supervisor Vladimir Rapić and advisors Srđanka Tomić and Mladen Žinić for introducing us into the subject. We also thank to our colleagues who contributed as co-authors to the joint researches. This work was supported by a grant from Croatian Science Foundation (project IP2014-09-7899).

\section{REFERENCES}

[1] T. J. Kealy, P. L. Pauson, Nature 1951, 168, 1039.

[2] G.Wilkinson, M. Rosenblum, M. C.Whiting, R. B.Woodward, J. Am. Chem. Soc. 1952, 74, 2125.
[3] R. B. Woodward, M. Rosenblum, M. C. Whiting, J. Am. Chem. Soc. 1952, 74, 3458.

[4] H. Werner, Angew. Chem. Int. Ed. 2012, 51, 2.

[5] D. Astruc, Eur. J. Inorg. Chem. 2017, 6.

[6] A. E. G. Cass, G. Davies, G. D. Francis, H. A. O. Hill, W. J. Aston, J. Higgins, E. V. Plotkin, L. D. L. Scott, A. P. F. Turner, Anal. Chem. 1984, 56, 667.

[7] M. Salmain, Labeling of Proteins with Organometallic Complexes: Strategies and Applications, in Bioorganometallics. Biomolecules, Labelling, Medicine (Ed. G. Jaouen), Wiley_VCH Verlag GmbH \& Co. KGaA, Weinheim, 2006, 181.

[8] a) G. Gasser, N. Metzler-Nolte, Curr. Opin. Chem. Biol. 2012, 16, 84; b) M. Patra, G. Gasser, Nat. Rev. Chem. 2017, 1, 0066.

[9] V. N. Babin, Yu. A. Belousov, V. I. Borisov, V. V. Gumenyuk, Yu. S. Nekrasov, L. A. Ostrovskaya, I. K. Sviridova, N. S. Sergeeva, A. A. Simenel, L. V. Snegur, Russ. Chem. Bull. Int. Ed. 2014, 63, 2405.

[10] G. Jaouen, A. Vessières, S. Top, Chem. Soc. Rev. 2015, 44, 8802.

[11] S. Top, A. Vessières, G. Leclercq, J. Quivy, J. Tang, J. Vaissermann, M. Huche, G. Jaouen, Chem. Eur. J. 2003, 9, 5223.

[12] A. A. Simenel, E. A. Morozova, L. V. Snegur, S. I. Zykova, V. V. Kachala, L. A. Ostrovskaya, N. V. Bluchterova, M. M. Fomina, Appl. Organomet. Chem. 2009, 23, 219.

[13] A. D. S. Krishna, G. Panda, A. K. Kondapi, Arch. Biochem. Biophys. 2005, 438, 206.

[14] B. Balaji, B. Balakrishnan, S. Perumalla, A. A. Karande, A. R. Chakravarty, Eur. J. Inorg. Chem. 2015, 1398.

[15] S. B. Deepthi, R. Trivedi, L. Giribabu, P. Sujitha, C. G. Kumar, Dalton Trans. 2013, 42, 1180.

[16] E. I. Edwards, R. Epton, G. Marr, J. Organomet. Chem. 1976, 107, 351.

[17] E. I. Edwards, R. Epton, G. Marr, J. Organomet. Chem. 1979, 168, 259.

[18] D. Scutaru, L. Tataru, I. Mazilu, E. Diaconu, T. Lixandru, C. Simionescu, J. Organomet. Chem. 1991, 401, 81.

[19] D. Scutaru, I. Mazilu, M. Vata, L. Tataru, A. Vlase, T. Lixandru, C. Simionescu, J. Organomet. Chem. 1991, $401,87$.

[20] L. V. Snegur, V. N. Babin, A. A. Simenel, Yu. S. Nekrasov, L. A. Ostrovskaya, N. S. Sergeeva, Russ. Chem. Bull. Int. Ed. 2010, 59, 2167.

[21] D. R. van Staveren, N. Metzler-Nolte, Chem. Rev. 2004, 104, 5931.

[22] H.-B. Kraatz, J. Inorg. Organomet. Polym. Materials 2005, 15, 83

[23] E. W. Neuse, J. Inorg. Organomet. Polym. Materials 2005, 15, 3. 
[24] S. Top, J. Tang, A. Vessières, C. Carrez, C. Provot, G. Jaouen, Chem. Commun. 1996, 955.

[25] G. Jaouen, S. Top, A. Vessières, G. Leclercq, J. Quivy, L. Jin, A. Croisy, C. R. Acad. Sci., Ser. Ilc: Chim. 2000, 3, 89.

[26] D. Dive, C. Biot, ChemMedChem. 2008, 3, 383.

[27] P. Štěpnička, Ferrocenes: Ligands, Materials and Biomolecules, John Wiley, Chichester, 2008.

[28] R. Ribić, M. Kovačević, V. Petrović-Peroković, I. Gruić-Sovulj, V. Rapić, S. Tomić, Croat. Chem. Acta 2010, 83, 421.

[29] M. Kovačević, L. Barišić, R. Ribić, V. Petrović Peroković, S. Tomić, V. Rapić, Appl. Organometal. Chem. 2012, 26, 74.

[30] G. Zhou, W. J. Mo, P. Sebbel, G. Min, T. A. Neubert, R. Glockshuber, X. R. Wu, T. T. Sun, X. P. Kong, J. Cell. Sci. 2001, 114, 4095.

[31] M. Hartmann, T. K. Lindhorst, Eur. J. Org. Chem. 2011, 3583.

[32] a) A. Nomoto, T. Moriuchi, S. Yamazaki, A. Ogawa, T. Hirao, Chem. Commun. 1998, 1963; b) T. Moriuchi, A. Nomoto, K. Yoshida, A. Ogawa, T. Hirao, J. Am. Chem. Soc. 2001, 123, 68; c) T. Moriuchi, T. Nagai, T. Hirao, Org. Lett. 2005, 7, 5265; d) T. Moriuchi, T. Nagai, T. Hirao, Org. Lett. 2006, 8, 31; e) T. Moriuchi, A. Nomoto, K. Yoshida, T. Hirao, J. Organomet. Chem. 1999, 589, 50; f) T. Moriuchi, A. Nomoto, K. Yoshida, T. Hirao, Organometallics 2001, 20, 1008; g) T. Moriuchi, T. Hirao, Acc. Chem. Res. 2010, 43, 1040; h) B. Adhikari, A. J. Lough, B. Barker, A. Shah, C. Xiang, H.-B. Kraatz, Organometallics 2014, 33, 4873; i) B. Adhikari, C. Singh, A. Shah, A. J. Lough, H.-B. Kraatz, Chem. Eur. J. 2015, 21, 11560.

[33] a) L. Barišić, M. Dropučić, V. Rapić, H. Pritzkow, S. I. Kirin, N. Metzler-Nolte, Chem. Commun. 2004, 17, 2004; b) L. Barišić, M. Čakić, K. A. Mahmoud, Y.-N. Liu, H.-B. Kraatz, H. Pritzkow, S. I. Kirin, N. MetzlerNolte, V. Rapić, Chem. Eur. J. 2006, 12, 4965; c) L. Barišić, V. Rapić, N. Metzler-Nolte, Eur. J. Inorg. Chem. 2006, 4019; d) M. Čakić Semenčić, D. Siebler, K. Heinze, V. Rapić, Organometallics 2009, 28, 2028; e) M. Čakić Semenčić, K. Heinze, C. Förster, V. Rapić, Eur. J. Inorg. Chem. 2010, 1089; f) J. Lapić, D. Siebler, K. Heinze, V. Rapić, Eur. J. Inorg. Chem. 2007, 14, 2014.

[34] S. Chowdhury, K. A. Mahmoud, G. Schatte, H.-B. Kraatz, Org. Biomol. Chem. 2005, 3, 3018.

[35] T. Moriuchi, T. Hirao, Kobunshi Ronbunshu 2016, 73, 1.

[36] M. Kovačević, I. Kodrin, S. Roca, K. Molčanov, Y. Shen, B. Adhikari, H.-B. Kraatz, L. Barišić, Chem. Eur. J. 2017, 23, 1037.

[37] T. Moriuchi, T. Nishiyama, M. Nobu, T. Hirao, Chem. Eur. J. 2017, 23, 12704.
[38] a) A. Lataifeh, S. Beheshti, H.-B. Kraatz, Eur. J. Inorg. Chem. 2009, 3205; b) T. Moriuchi, T. Hirao, J. Inclusion Phenom. Macrocyclic Chem. 2012, 74, 23.

[39] V. Rapić, M. Kovačević, Kem. Ind. 2012, 61, 71.

[40] M. Massimi, A. Tomassini, F. Sciubba, A. P. Sobolev, L. Conti Devirgiliis, A. Miccheli, Biochim. Biophys. Acta 2012, 1820, 1.

[41] J. Das, S. Pany, A. Majhi, Bioorg. Med. Chem. 2011, 19, 5321.

[42] F. Mazué, D. Colin, J. Gobbo, M. Wegner, A. Rescifina, C. Spatafora, D. Fasseur, D. Delmas, P. Meunier, C. Tringali, N. Latruffe, Eur. J. Med. Chem. 2010, 452972.

[43] Q. Liu, C. T. Kim, Y. H. Jo, S. B. Kim, B. Y. Hwang, M. K. Lee, Molecules 2015, 20, 16933.

[44] M. Chalal, D. Delmas, P. Meunier, N. Latruffe, D. Vervandier-Fasseur, Molecules 2014, 19, 7850.

[45] V. Kovač, I. Kmetič, T. Murati, M. Miletić, L. Barišić, Croat. Chem. Acta 2016, 89, 339.

[46] I. Held, P. von den Hoff, D. S. Stephenson, H. Zipse, Adv. Synth. Catal. 2008, 350, 1891.

[47] a) J. Bouckaert, J. Berglund, M. Schembri, E. De Genst, L. Cools, M. Wuhrer, C.-S. Hung, J. Pinkner, R. Slättegård, A. Zavialov, D. Choudhury, S. Langermann, S. J. Hultgren, L. Wyns, P. Klemm, S. Oscarson, S. D. Knight, H. De Greve, Mol. Microbiol. $\mathbf{2 0 0 5}, 55,441$; b) A. Wellens, C. Garofalo, H. Nguyen, N. Van Gerven, R. Slättegård, J.-P. Hernalsteens, L. Wyns, S. Oscarson, H. De Greve, S. Hultgren, J. Bouckaert, PLOS ONE 2008, 3, e2040.

[48] V. Kovač, R. Ribić, V. Petrović Peroković, S. Tomić Pisarović, L. Barišić, Appl. Organometal. Chem. 2016, 30, 524.

[49] E. Ko, J. Liu, K. Burgess, Chem. Soc. Rev. 2011, 40, 4411.

[50] A. Giannis, T. Kolte, Angew. Chem. Int. Ed. Engl. 1993, 32, 1244.

[51] P. Čudić, M. Stawikowski, Methods Mol. Biol. 2008, 494, 223.

[52] J. M. Lozano, L. P. Lesmes, L. F. Carreño, G. M. Gallego, M. Elkin Patarroyo, Molecules 2010, 15, 8856.

[53] P. Wipf, J. Xiao, C. R. J. Stephenson, Chimia (Aarau) 2009, 63, 764.

[54] C. Z. Gómez-Castro, I. I. Padilla-Martínez, E. V. García-Báez, J. L. Castrejón-Flores, A. L. PerazaCampos, F. J. Martínez-Martínez, Molecules 2014, $19,14446$.

[55] X.-W. Li, Y.-J. Zheng, Y.-T. Li, Z.-Y. Wu, C.-W. Yan, Eur. J. Med. Chem. 2011, 46, 3851.

[56] J. Jiao, M. Jiang, Y.-T. Li, Z.-Y. Wu, C.-W. Yan, J. Biochem. Mol. Toxicol. 2014, $28,47$.

[57] K. Zheng, L. Jiang, Y.-T. Li, Z.-Y. Wu, C.-W.Yan, RSC Adv. 2015, 5, 51730. 
[58] N. Sunduru, M. Sharma, K. Srivastava, S. Rajakumar, S. K. Puri, J. K. Saxena, P. M. S. Chauhan, Bioorg. Med. Chem. 2009, 17, 6451.

[59] K. O. Yerdelen, E. Tosun, Med. Chem. Res. 2015, 24, 588.

[60] F. Currelia, Y. D. Kwon, H. Zhang, D. Scacalossi, D. S. Belov, A. A. Tikhonov, I. A. Andreev, A. Altieri, A. V. Kurkin, P. D. Kwong, A. K. Debnath, J. Med. Chem. 2015, 58, 6909.

[61] S. M. Curtis, N. Le, F. W. Fowler, J. W. Lauher, Cryst. Growth Des. 2005, 5, 2313.

[62] Z.-L. Liu, L.-Cun, D.-Z. Liao, Z.-H. Jiang, S.-P. Yan, Cryst. Growth Des. 2005, 5, 783.

[63] a) J. Makarević, M. Jokić, L. Frkanec, V. Čaplar, N. Šijaković Vujičić, M. Žinić, Beilstein J. Org. Chem. 2010, 6, 945; b) L. Frkanec, M. Žinić, Chem. Commun. 2010, 46, 522; c) J. Makarević, M. Jokić, Z. Raza, V. Čaplar, D. Katalenić, Z. Štefanić, B. Kojić-Prodić, M. Žinić, Croat. Chem. Acta 2004, 77, 403; d) J. Makarević, M. Jokić, B. Perić, V. Tomišić, B. KojićProdić, M. Žinić, Chem. Eur. J. 2001, 7, 3328.

[64] E. F. Montero-Vázquez, F. J. Martínez-Martínez, I. I. Padilla-Martínez, M. A. Carvajal-García, J. Hernández-Díaz, ARKIVOC 2008, 276.

[65] I. L. Karle, D. Ranganathan, K. Shah, N. K. Vaish, Int. J. Pept. Protein Res. 1994, 43, 160.

[66] S. Coe, J. J. Kane, T. L. Nguyen, L. M. Toledo, E. Wininger, F. W. Fowler, J. W. Lauher, J. Am. Chem. Soc. 1997, 119, 86.

[67] V. Kovač, K. Radošević, A. Bebek, J. Makarević, Z. Štefanić, L. Barišić, M. Žinić, V. Rapić, Appl. Organometal. Chem. 2017, 31, e3653.

[68] C. Tomasini, N. Castellucci, Chem. Soc. Rev. 2013, 42, 156.
[69] E. J. Calabrese, L. A. Baldwin, Annu. Rev. Pharmacol. Toxicol. 2003, 43, 175.

[70] M. P. Mattson, Ageing Res. Rev. 2008, 7, 1.

[71] G. Vanhoof, F. Goossens, I. De Meester, D. Hendriks, S. Scharpé, FASEB J. 1995, 9, 736.

[72] B. K. Kay, M. P. Williamson, M. Sudol, FASEB J. 2000, 14, 231

[73] A. Troganis, I. P. Gerothanassis, Z. Athanassiou, T. Mavromoustakos, G. E. Hawkes, C. Sakarellos, Biopolymers 2000, 53, 72.

[74] M. Kovačević, K. Molčanov, K. Radošević, V. Gaurina Srček, S. Roca, A. Čače, L. Barišić, Molecules. 2014, 19, 12852.

[75] L. Barišić, M. Kovačević, M. Mamić, I. Kodrin, Z. Mihalić, V. Rapić, Eur. J. Inorg. Chem. 2012, 11, 1810.

[76] T. Hayashi, T. Asai, H. Ogoshi, Tetrahedron Let. 1997 , 38, 3039.

[77] M. Čakić Semenčić, V. Kovač, I. Kodrin, L. Barišić, V. Rapić, Eur. J. Inorg. Chem. 2015, 112.

[78] V. Kovač, M. Čakić Semenčić, I. Kodrin, S. Roca, V. Rapić, Tetrahedron 2013, 69, 10497.

[79] M. Iqbal, P. Balaram, J. Am. Chem. Soc. 1981, 103, 5548.

[80] Y. V. Venkatachalapathi, B. V. V. Prasad, P. Balaram, Biochemistry 1982, 2, 5502.

[81] J. L. Jios, S. I. Kirin, N. N. Buceta, T. Weyhmuller, C. O. Della Vedova and N. Metzler-Nolte, J. Organomet. Chem. 2007, 692, 4209.

[82] M. Čakić Semenčić, I. Kodrin, L. Barišić, M. Nuskol, A. Meden, Eur. J. Inorg. Chem. 2017, 306.

[83] M. Kovačević, I. Kodrin, M. Cetina, I. Kmetič, T. Murati, M. Čakić Semenčić, S. Roca, L. Barišić, Dalton Trans. 2015, 44, 16405.

[84] M. Kovačević, V. Rapić, I. Lukač, K. Molčanov, I. Kodrin, L. Barišić, J. Mol. Struct. 2013, 1048, 349. 